\title{
Air-snowpack exchange of bromine, ozone and mercury in the springtime Arctic simulated by the 1-D model PHANTAS - Part 1: In-snow bromine activation and its impact on ozone
}

\author{
K. Toyota ${ }^{1,2}$, J. C. McConnell ${ }^{1, \dagger}$, R. M. Staebler ${ }^{3}$, and A. P. Dastoor ${ }^{4}$ \\ ${ }^{1}$ Department of Earth and Space Science and Engineering, York University, Toronto, Ontario, Canada \\ ${ }^{2}$ Air Quality Modelling and Integration Section, Environment Canada, Toronto, Ontario, Canada \\ ${ }^{3}$ Air Quality Processes Section, Environment Canada, Toronto, Ontario, Canada \\ ${ }^{4}$ Air Quality Modelling and Integration Section, Environment Canada, Dorval, Quebec, Canada \\ $\dagger$ deceased, 29 July 2013 \\ Correspondence to: K. Toyota (kenjiro.toyota@ec.gc.ca)
}

Received: 9 May 2013 - Published in Atmos. Chem. Phys. Discuss.: 5 August 2013

Revised: 10 February 2014 - Accepted: 27 February 2014 - Published: 25 April 2014

\begin{abstract}
To provide a theoretical framework towards a better understanding of ozone depletion events (ODEs) and atmospheric mercury depletion events (AMDEs) in the polar boundary layer, we have developed a one-dimensional model that simulates multiphase chemistry and transport of trace constituents from porous snowpack and through the atmospheric boundary layer (ABL) as a unified system. This paper constitutes Part 1 of the study, describing a general configuration of the model and the results of simulations related to reactive bromine release from the snowpack and ODEs during the Arctic spring. A common set of aqueous-phase reactions describes chemistry both within the liquid-like layer (LLL) on the grain surface of the snowpack and within deliquesced "haze" aerosols mainly composed of sulfate in the atmosphere. Gas-phase reactions are also represented by the same mechanism in the atmosphere and in the snowpack interstitial air (SIA). Consequently, the model attains the capacity of simulating interactions between chemistry and mass transfer that become particularly intricate near the interface between the atmosphere and the snowpack. In the SIA, reactive uptake on LLL-coated snow grains and vertical mass transfer act simultaneously on gaseous $\mathrm{HOBr}$, a fraction of which enters from the atmosphere while another fraction is formed via gas-phase chemistry in the SIA itself. A "bromine explosion", by which $\mathrm{HOBr}$ formed in the ambient air is deposited and then converted heterogeneously to $\mathrm{Br}_{2}$, is found to be a dominant process of reactive bromine formation in the
\end{abstract}

top $1 \mathrm{~mm}$ layer of the snowpack. Deeper in the snowpack, $\mathrm{HOBr}$ formed within the SIA leads to an in-snow bromine explosion, but a significant fraction of $\mathrm{Br}_{2}$ is also produced via aqueous radical chemistry in the LLL on the surface of the snow grains. These top- and deeper-layer productions of $\mathrm{Br}_{2}$ both contribute to the release of $\mathrm{Br}_{2}$ to the atmosphere, but the deeper-layer production is found to be more important for the net outflux of reactive bromine. Although ozone is removed via bromine chemistry, it is also among the key species that control both the conventional and in-snow bromine explosions. On the other hand, aqueous-phase radical chemistry initiated by photolytic $\mathrm{OH}$ formation in the LLL is also a significant contributor to the in-snow source of $\mathrm{Br}_{2}$ and can operate without ozone, whereas the delivery of $\mathrm{Br}_{2}$ to the atmosphere becomes much smaller after ozone is depleted. Catalytic ozone loss via bromine radical chemistry occurs more rapidly in the SIA than in the ambient air, giving rise to apparent dry deposition velocities for ozone from the air to the snow on the order of $10^{-3} \mathrm{~cm} \mathrm{~s}^{-1}$ during daytime. Overall, however, the depletion of ozone in the system is caused predominantly by ozone loss in the ambient air. Increasing depth of the turbulent ABL under windy conditions will delay the buildup of reactive bromine and the resultant loss of ozone, while leading to the higher column amount of $\mathrm{BrO}$ in the atmosphere. During the Arctic spring, if moderately saline and acidic snowpack is as prevalent as assumed in our model runs on sea ice, the shallow, stable ABL under 
calm weather conditions may undergo persistent ODEs without substantial contributions from blowing/drifting snow and wind-pumping mechanisms, whereas the column densities of $\mathrm{BrO}$ in the $\mathrm{ABL}$ will likely remain too low in the course of such events to be detected unambiguously by satellite nadir measurements.

\section{Introduction}

Discoveries of rapid depletion events for ozone and mercury from the atmospheric boundary layer (ABL) in springtime polar regions of both hemispheres (e.g., Oltmans, 1981; Bottenheim et al., 1986; Schroeder et al., 1998; Wessel et al., 1998; Ebinghaus et al., 2002) have motivated many experimental, observational, and modeling studies to decipher key mechanisms behind this phenomenon (Simpson et al., 2007; Steffen et al., 2008; Abbatt et al., 2012, and references therein). Called ozone depletion events (ODEs) and atmospheric mercury depletion events (AMDEs), they have been observed to occur concurrently in most cases. It is now widely accepted that chain reactions involving $\mathrm{Br}$ atoms and $\mathrm{BrO}$ radicals (and $\mathrm{IO}$ and $\mathrm{ClO}$ radicals working synergistically with $\mathrm{BrO}$ under some circumstances) are responsible for the photochemical loss of ozone and gaseous elemental mercury during such events (Barrie et al., 1988; Hausmann and Platt, 1994; Jobson et al., 1994; Sander et al., 1997; Tuckermann et al., 1997; Frieß et al., 2001; Calvert and Lindberg, 2004; Saiz-Lopez et al., 2007, 2008; Pöhler et al., 2010; Mahajan et al., 2010), in air masses that have had recent contact with sea ice (Bottenheim et al., 1990, 2009; Hopper and Hart, 1994; Hopper et al., 1998; Frieß et al., 2004; Morin et al., 2005; Hirdman et al., 2009; Seabrook et al., 2011, 2013).

A major involvement of bromine radical chemistry in ODEs was first confirmed by ground-based long-path DOAS (differential optical absorption spectroscopy) measurements to detect $\mathrm{BrO}$ as high as $17 \mathrm{pmol} \mathrm{mol}^{-1}$ at Alert, located at the northern tip of Canada's most northerly island (Hausmann and Platt, 1994). Several years later, space-borne measurements applied the DOAS technique to spectra of sunlight reflected and/or scattered back from the Earth and revealed a widespread occurrence of high $\mathrm{BrO}$ column amounts over polar ice covers in both hemispheres during the spring (Chance, 1998; Richter et al., 1998; Wagner and Platt, 1998). Such measurements have been considered as unequivocal evidence to support the prevalence of high $\mathrm{BrO}$ levels in the ABL sustained by active bromine release from sea ice. Some aircraft measurements, however, indicated high $\mathrm{BrO}$ levels in the free troposphere as well (McElroy et al., 1999; Choi et al., 2012). Additionally, if one adopts the high end of uncertainty range in $\mathrm{BrO}$ levels within the upper troposphere and lower stratosphere (UTLS) region, most of the enhanced total $\mathrm{BrO}$ columns can be accounted for by changing partial
$\mathrm{BrO}$ columns associated with atmospheric dynamics in the UTLS (Salawitch et al., 2010). To deal with these problems, a couple of recent studies employed stringent screening and subtraction procedures to analyze satellite $\mathrm{BrO}$ column data, providing more confidence in the frequent and widespread (albeit somewhat less than initially implied) occurrence of enhanced $\mathrm{BrO}$ columns in the springtime polar boundary layer (Theys et al., 2011; Sihler et al., 2012).

Various forms of salinized ice materials exist prevalently on sea ice and may react heterogeneously with atmospheric oxidants either directly as surface-bound snow/ice packs (McConnell et al., 1992; Michalowski et al., 2000; Simpson et al., 2005; Piot and von Glasow, 2008) or as lofted snow particles when windy (Rankin et al., 2002; Kaleschke et al., 2004; Yang et al., 2008; Jones et al., 2009; Frieß et al., 2011). Furthermore, if certain conditions are met, gaseous reactive halogens are released efficiently to the atmosphere. The appropriate conditions for halogen release have not yet to be established conclusively but appear to involve low temperature, sunlight and the acidity of the substrate (e.g., Fickert et al., 1999; Adams et al., 2002; Huff and Abbatt, 2002; Abbatt et al., 2010; Oldridge and Abbatt, 2011; Pratt et al., 2013). Our knowledge is still insufficient to answer clearly which of the speculated processes can indeed account for the buildup of reactive halogens and the subsequent depletion of ozone and mercury as observed under different meteorological and sea-ice phenomenological conditions (e.g., Toyota et al., 2011; Buys et al., 2013).

One suggestion on the source of reactive bromine during ODEs/AMDEs is that it is delivered mainly via a sequence of multiphase reactions called "bromine explosion" (Platt and Lehrer, 1996; Wennberg, 1999; Simpson et al., 2007):

$$
\begin{aligned}
& \mathrm{HOBr}+\mathrm{Br}_{\mathrm{aq}}^{-}+\mathrm{H}_{\mathrm{aq}}^{+} \rightarrow \mathrm{Br}_{2}+\mathrm{H}_{2} \mathrm{O} \\
& \mathrm{Br}_{2}+h v \rightarrow 2 \mathrm{Br} \\
& \mathrm{Br}+\mathrm{O}_{3} \rightarrow \mathrm{BrO}+\mathrm{O}_{2} \\
& \mathrm{BrO}+\mathrm{HO}_{2} \rightarrow \mathrm{HOBr}+\mathrm{O}_{2} \\
& \text { net: } \mathrm{H}_{\mathrm{aq}}^{+}+\mathrm{Br}_{\mathrm{aq}}^{-}+\mathrm{HO}_{2}+\mathrm{O}_{3} \rightarrow \mathrm{Br}+\mathrm{H}_{2} \mathrm{O}+2 \mathrm{O}_{2} .
\end{aligned}
$$

Here, the net release of bromine from the condensed phase (e.g., snow, aerosols) to the gas phase is facilitated autocatalytically while consuming $\mathrm{O}_{3}$ and $\mathrm{HO}_{2}$ in the gas phase and protons in the condensed phase. Note also, the multiphase Reaction (R1) is probably an abbreviation of multiple reaction steps which proceed via the formation of aqueous-phase intermediates $\mathrm{BrCl}_{\mathrm{aq}}$ and $\mathrm{Br}_{2} \mathrm{Cl}_{\mathrm{aq}}^{-}$, as chloride $\left(\mathrm{Cl}^{-}\right)$is often a few orders of magnitude more concentrated than bromide $\left(\mathrm{Br}^{-}\right)$in polar snow on sea ice and over land near the coast (Simpson et al., 2007, and references therein):

$$
\begin{aligned}
& \mathrm{HOBr}+\mathrm{Cl}_{\mathrm{aq}}^{-}+\mathrm{H}_{\mathrm{aq}}^{+} \rightarrow \mathrm{BrCl}_{\mathrm{aq}}+\mathrm{H}_{2} \mathrm{O} \\
& \mathrm{BrCl}_{\mathrm{aq}}+\mathrm{Br}_{\mathrm{aq}}^{-} \rightleftarrows \mathrm{Br}_{2} \mathrm{Cl}_{\mathrm{aq}}^{-} \\
& \mathrm{Br}_{2} \mathrm{Cl}_{\mathrm{aq}}^{-} \rightleftarrows \mathrm{Br}_{2 \mathrm{aq}}+\mathrm{Cl}_{\mathrm{aq}}^{-} .
\end{aligned}
$$


Earliest attempts to simulate the bromine explosion were made by box models with an ad hoc assignment of the ventilation rate between near-surface ambient air (where $\mathrm{HOBr}$ is produced via Reaction R4) and saline snowpack (where $\mathrm{HOBr}$ is consumed to produce $\mathrm{Br}_{2}$ via Reaction R1) (Tang and McConnell, 1996; Michalowski et al., 2000). It was implicitly assumed that the porous nature of snowpack allowed for the efficient access of ambient air throughout the bulk of the snowpack especially when ventilated by a wind-pumping process (Cunningham and Waddington, 1993). From the modeling viewpoint, this is equivalent, at least qualitatively, to placing wind-blown snow (Jones et al., 2009) and its sublimated residues (Yang et al., 2008) in the ambient air, as all the approaches will increase the effective surface area of saline snow that can interact with oxidants in the ambient air under windy conditions. On the other hand, Lehrer et al. (2004) assumed that Reaction (R1) could be represented essentially by the dry deposition of $\mathrm{HOBr}$ from the atmosphere onto the top of the snowpack; in their one-dimensional (1-D) model of chemistry and diffusion in the ABL, it took more than 20 days from the initial buildup of reactive bromine to the near-complete depletion of ozone. This timescale is much longer than 2-5 days as simulated by aforementioned box models in which bulk snowpack was assumed to interact with ventilated air (Tang and McConnell, 1996; Michalowski et al., 2000). Unfortunately, the remote and harsh polar environment constrains logistics for field observations so that, whether based at coastal stations, ships, buoys or aircrafts, they have been generally too sparse to track a full time evolution of chemical species in a specific air mass over snow/ice surfaces. Some observations, however, encountered cases suggesting strongly that the buildup of reactive halogens and subsequent ozone depletion progressed even within a day or less (Boudries and Bottenheim, 2000; Jacobi et al., 2006). On the other hand, Bottenheim and Chan (2006) indicated several days as a typical timescale for the progress of ODEs in air masses arriving at Alert.

In their 1-D model of gas/aerosol chemistry and turbulent diffusion in the ABL, Piot and von Glasow (2008) represented the snowpack as a medium in which an empirically chosen fraction of inorganic bromine compounds, after deposited from the atmosphere, was instantaneously converted to photolabile $\mathrm{Br}_{2}$ and $\mathrm{BrCl}$ and released back to the atmosphere. Although that model did not address actual processes taking place within the snowpack, it also indicated a major role of snowpack chemistry by predicting that the recycling of bromine from the snowpack controlled the timescale and magnitude of ozone depletion as initiated by wind-lofting of frost flowers from refrozen leads. In addition to reactive bromine itself, impurities in the snowpack, especially when irradiated by sunlight, can give rise to significant emissions of short-lived chemical species including nitrogen oxides (NO, $\mathrm{NO}_{2}$ and $\mathrm{HONO}$ ) and aldehydes that can interact strongly with bromine chemistry in the gas phase (Grannas et al., 2007, and references therein). This, along with the abundance of ice surfaces available for heterogeneous reactions, will make a chemical environment in the interstitial air of the snowpack distinctly different from that in overlying ambient air. Some of these aspects were recently addressed by Thomas et al. (2011) in their 1-D model of multiphase chemistry and transport supposedly occurring in both the snowpack and the overlying near-surface air at Summit, Greenland. They simulated primary sources of gaseous bromine and nitrogen oxides from condensed-phase photochemistry and in-snow multiphase recycling such as Reactions (R1)-(R4), under the assumption that snowpack impurities are located mostly in a liquid-like layer (LLL) on the surface of snow grains in contact with the interstitial air. This model was found to simulate the ambient-air concentrations of $\mathrm{NO}$ and $\mathrm{BrO}$ in excellent agreement with field measurements, supporting the correctness of implemented chemical and physical mechanisms at least conceptually.

In this work, we have developed a 1-D air-snowpack photochemical model to explore the potential role of insnow multiphase chemical processes in the buildup of reactive bromine and the depletion of ozone and mercury in the springtime polar boundary layer. As we represent atmospheric aerosols by a "haze" mainly composed of sulfate, our present focus is placed on chemistry in the Arctic rather than in the Antarctic. A general framework of our model, especially its representation of snowpack chemistry and physics and their coupling with processes in the overlying air, is similar to the one developed by Thomas et al. (2011) for the study of snowpack chemistry atop the Greenland ice sheet. However, our model also includes a detailed mechanism of multiphase mercury chemistry and hypothesizes vertical mass transfer through the LLL in the snowpack. We present the results, obtained by using a common model set-up with the same governing equations and chemical mechanisms, in two papers. This paper (Part 1) starts from the description of common physical and chemical processes included in our model, PHANTAS (a model of PHotochemistry ANd Transport between Air and Snowpack) (Sect. 2). Model simulations are then discussed with a focus on the mechanism for the release of reactive bromine and how it builds up in the snowpack and in the ABL under different conditions in meteorology (dictated by surface wind speeds) and in acidity and bromide content within snowpack (Sect. 3). Model description and simulations concerning the chemistry of mercury will be presented in Part 2 (Toyota et al., 2014). In developing PHANTAS, great attention was given to a numerical configuration of the model for unequivocally resolving different outcomes of chemical processes in the snowpack and the overlying ambient air as well as a close connection between the two domains near the top of the snowpack by means of gas diffusion. This issue had not been addressed explicitly in most of the past modeling studies. 


\section{Model description}

\subsection{Overview}

PHANTAS is a 1-D model that describes multiphase chemistry and vertical transport of gaseous and aqueous trace constituents through a porous snowpack and in the overlying ambient air (Fig. 1). Currently, the model is designed such that it is best suited to simulate ODEs and AMDEs in the ABL during the Arctic spring. It consists of 55 vertical layers, among which 22 layers represent the porous snowpack of $35 \mathrm{~cm}$ in depth as typically observed on Arctic sea ice in spring (Warren et al., 1999; Sturm et al., 2002), while the remaining 33 layers represent the turbulent ABL and extra layers in the free troposphere. The model solves a set of partial differential equations describing the temporal and vertical evolution of concentrations for chemical species of interest:

$$
\begin{aligned}
\phi \frac{\partial C_{\mathrm{g}}}{\partial t}= & \phi\left[\frac{\partial}{\partial z}\left(D_{\mathrm{g}, z} \frac{\partial C_{\mathrm{g}}}{\partial z}\right)+P_{\mathrm{g}}-L_{\mathrm{g}} C_{\mathrm{g}}\right]+S_{g} \\
& -(1-\phi) k_{\mathrm{t}}\left(C_{\mathrm{g}}-\frac{C_{\mathrm{a}}}{K_{\mathrm{H}} R T}\right) \\
\frac{\partial C_{\mathrm{a}}}{\partial t}= & \frac{\partial}{\partial z}\left(D_{\mathrm{a}, \mathrm{z}} \frac{\partial C_{\mathrm{a}}}{\partial z}\right)+P_{\mathrm{a}}-L_{\mathrm{a}} C_{\mathrm{a}}+\frac{k_{\mathrm{t}}}{f_{\mathrm{q}}}\left(C_{\mathrm{g}}-\frac{C_{\mathrm{a}}}{K_{\mathrm{H}} R T}\right),
\end{aligned}
$$

where $C_{\mathrm{g}}$ (in moles per liter of air) and $C_{\mathrm{a}}$ (in mole per liter of liquid water volume) are the concentrations of chemical species in the gas phase and in the aqueous phase, respectively; $D_{\varphi, z}$ is vertical diffusivity; $P_{\varphi}$ and $L_{\varphi}$ are chemical production and loss terms, respectively, in the gas phase (if $\varphi=g$ ) or in the aqueous phase (if $\varphi=a$ ); $S_{g}$ is an ad hoc source term for selected gaseous species (used here for in-snow photochemical release of $\mathrm{HCHO}$ and $\left.\mathrm{CH}_{3} \mathrm{CHO}\right) ; \phi$ is the porosity of the snowpack or $\phi \sim 1$ (but $\phi \neq 1$ owing to the volume of aerosols) in the ambient air; $k_{\mathrm{t}}$ is a mass transfer coefficient between gas and condensed phases (in $\mathrm{s}^{-1}$ ); $K_{\mathrm{H}}$ is Henry's law coefficient (in $\mathrm{molL}^{-1} \mathrm{~atm}^{-1}$ ); $R$ is gas constant $\left(=0.082 \mathrm{Latm} \mathrm{mol}^{-1} \mathrm{~K}^{-1}\right) ; T$ is temperature (in Kelvin); and $f_{\mathrm{q}}$ is a volume fraction of the LLL surrounding snow grains (see Sect. 2.5) or $f_{\mathrm{q}}=1$ for deliquesced aerosols in the ambient air. The rate of mass transfer between gas and aqueous phases $\left(k_{\mathrm{t}}\right)$ is calculated based on the algorithm by Schwartz (1986):

$k_{\mathrm{t}}=\left(\frac{r^{2}}{3 D_{\mathrm{g}, \mathrm{mol}}}+\frac{4 r}{3 \bar{v} \alpha_{\mathrm{m}}}\right)^{-1}$,

where $r$ is the radius of snow grains (in the snowpack) or aerosols (in the atmosphere) for both of which monodisperse spheres are assumed, and $D_{\mathrm{g}, \mathrm{mol}}, \bar{v}$, and $\alpha_{\mathrm{m}}$ are molecular diffusivity, mean thermal velocity, and mass accommodation coefficient, respectively, for a gas molecule of interest.

In the ambient air, gaseous and aerosol species are dispersed vertically by turbulent diffusion (for both gases/aerosols), molecular diffusion (for gases) or Brownian

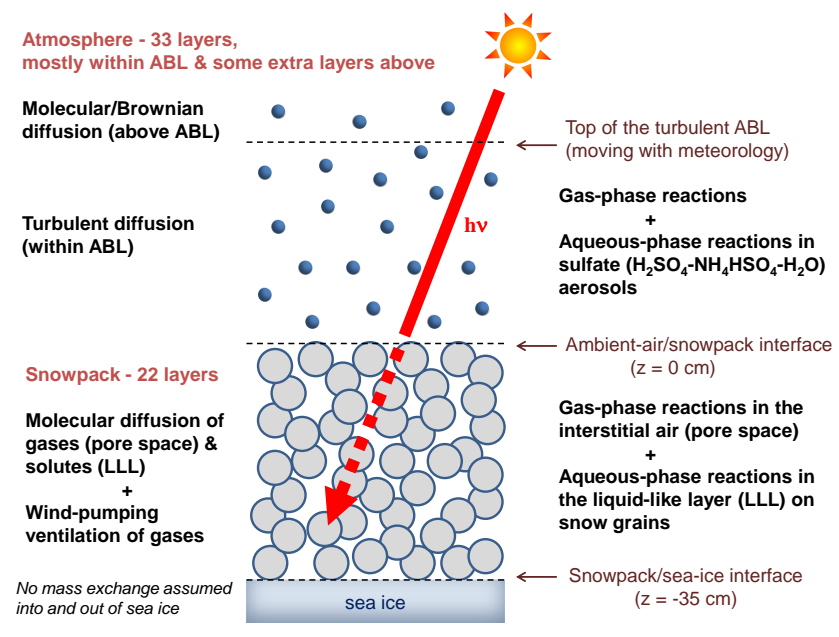

Fig. 1. Vertical domains and physical/chemical processes represented by PHANTAS.

diffusion (for aerosols) depending on height and meteorological conditions (Sect. 2.7). Gas diffusion is assumed to occur further down into the snowpack interstitial air (SIA), within which the effect of wind pumping is superimposed to the molecular diffusivity in a simplified fashion (Sect. 2.4). In the snowpack, all the condensed-phase reactants and products are assumed to be contained in the LLL on the surface of snow grains (Sect. 2.5). Also, the LLL is assumed to be connected between the neighboring snow grains across the entire depth of the snowpack, facilitating the vertical molecular diffusion of snow-trapped, aqueous-phase trace constituents although at much lower rates than gaseous molecular diffusion in the SIA (Sect. 2.6). Table 1 summarizes parameterizations adopted for calculating the vertical diffusion coefficients $\left(D_{\mathrm{g}, z}\right.$ and $\left.D_{\mathrm{a}, \mathrm{z}}\right)$ in Eqs. (1) and (2) in different model domains.

The snowpack is assumed to be made up of uniformly packed, monodisperse ice spheres with the bulk density of $0.31 \mathrm{~g} \mathrm{~cm}^{-3}$ as in the box model by Michalowski et al. (2000). By taking the ice mass density as $0.92 \mathrm{~g} \mathrm{~cm}^{-3}$, the porosity, $\phi$, is calculated to be 0.663 and the total condensed (liquid + solid) water content, $(1-\phi) / \phi$, is calculated to be $0.508 \mathrm{~cm}^{3}$ (liquid + solid) $\mathrm{cm}^{-3}$ (air). To obtain the specific surface area (SSA) consistent with measurements for Arctic snowpack during the spring (Domine et al., 2002), the diameter of snow grains is adjusted to $0.3 \mathrm{~mm}$, which leads to the SSA of $217 \mathrm{~cm}^{2} \mathrm{~g}^{-1}$ of ice. Expressed in different units, the ratio of surface area to air volume in the SIA is $101 \mathrm{~cm}^{2} \mathrm{~cm}^{-3}$ of SIA volume or $67 \mathrm{~cm}^{2} \mathrm{~cm}^{-3}$ of bulk snowpack volume.

Mass continuity equations in the atmosphere, which is assumed to contain aerosols in the liquid state, are also handled by Eqs. (1)-(3) with $\phi \sim 1$ and $f_{\mathrm{q}}=1$. The liquid water content of aerosols is thus given by $(1-\phi) / \phi$. Vertical transfer of aqueous-phase species from the atmosphere to the snowpack via dry deposition of aerosols is handled by including 
Table 1. Parameterizations used for the vertical diffusivity of gaseous and aqueous-phase (atmospheric aerosols and snowpack LLL) composition in different model domains.

\begin{tabular}{llll}
\hline & Snowpack & \multicolumn{2}{c}{ Atmosphere } \\
\cline { 3 - 4 } & & $z<Z_{\mathrm{ABL}}$ & $z \geq Z_{\mathrm{ABL}}^{\mathrm{a}}$ \\
\hline Gas-phase species, $D_{\mathrm{g}, z}$ & $D_{\mathrm{SIA}}$, Eq. (5) & $K(z)$, Eq. (10) & $D_{\mathrm{g}, \text { mol }}^{\mathrm{b}}$ \\
Aqueous-phase species, $D_{\mathrm{a}, \mathrm{z}}$ & $D_{\mathrm{LLL}}$, Eq. (9) & $K(z)$, Eq. (10) & $D_{\mathrm{B}}^{\mathrm{c}}$ \\
\hline
\end{tabular}

${ }^{\mathrm{a}} Z_{\mathrm{ABL}}$ is the depth of the turbulent ABL calculated diagnostically by Eq. (12).

${ }^{\mathrm{b}} D_{\mathrm{g}, \mathrm{mol}}$ is the molecular diffusivity of gaseous molecules in air and calculated according to Fuller et al.

$(1966,1969)$ for non-mercury species. See Toyota et al. $(2014)$ how it is calculated for mercury species.

${ }^{\mathrm{c}} D_{\mathrm{B}}$ is the Brownian diffusivity of aerosols in air and calculated according to Seinfeld and Pandis (1998).

an additional term in Eq. (2) as described in Sect. 2.8. On the other hand, no additional term is introduced for the exchange of gas-phase species between the snowpack and the atmosphere. Since compounds like $\mathrm{O}_{3}$ (actively lost via catalytic reactions involving bromine radicals) and $\mathrm{HOBr}$ (taken up quickly by saline snow grains) generally maintain lower mixing ratios in the SIA than in the surface ambient air, "apparent" dry deposition velocities for such gases are dictated by physical and chemical processes included in the model.

\subsection{Chemical mechanism}

Except for reactions involving mercury, the chemical mechanism is adapted from Toyota et al. (2004), which was designed for simulating the multiphase chemistry of the $\mathrm{O}_{\mathrm{x}}-$ $\mathrm{HO}_{\mathrm{x}}-\mathrm{NO}_{\mathrm{x}}-\operatorname{VOCs}\left(\leq \mathrm{C}_{3}\right)-$ sulfur $-\mathrm{ClO}_{\mathrm{x}}-\mathrm{BrO}_{\mathrm{x}}$ system involving sea-salt aerosols in the marine boundary layer. $\mathrm{A}$ full list of reactions included in PHANTAS can be found in the Supplement (Sect. S1). It should be noted that aerosols in the present model are solely represented by "haze" aerosols composed mainly of sulfate (see Sect. 2.8); thus, lofting of particles and aerosols from saline ice/snow surfaces (i.e., blowing/drifting snow) is not addressed here (cf. Yang et al., 2008). New additions related to mercury chemistry are described in Part 2 of this study (Toyota et al., 2014). Here we highlight major changes from Toyota et al. (2004) in the nonmercury part of the chemical mechanism.

First, Toyota et al. (2004) accounted for the photochemistry of up to $\mathrm{C}_{3}$ hydrocarbons and their impacts on halogen chemistry in detail (e.g., addition reactions of halogen-atoms to alkenes). Since many of these reactions were speculative on their actual occurrence but included for exploratory reasons, they are excluded in the present study except for reactions involving $\mathrm{CH}_{4}, \mathrm{C}_{2} \mathrm{H}_{6}, \mathrm{C}_{2} \mathrm{H}_{2}$ and their photodegradation products. Among these, $\mathrm{HCHO}, \mathrm{CH}_{3} \mathrm{CHO}$, and $\mathrm{C}_{2} \mathrm{H}_{2}$ are of prime importance for scavenging $\mathrm{Br}$-atoms via gasphase reactions. Second, changes have been made in temperature dependence for the equilibrium constant of Reaction (R6) (Sander et al., 2006) and in the products of the aqueous-phase reaction $\mathrm{Br}_{2}^{-}+\mathrm{HO}_{2}$ from $2 \mathrm{Br}^{-}+\mathrm{H}^{+}+\mathrm{O}_{2}$ to $\mathrm{Br}_{2}+\mathrm{HO}_{2}^{-}$(Matthew et al., 2003). Third, following the chemical mechanism developed by Herrmann et al. (2003) for the gas-aerosol-cloud system, we now assume that Bratoms are subject to mass transfer between gas and aqueous phases. Last, for some of the critical photolysis reactions in the aqueous phase, absorption cross sections, quantum yields and their temperature dependence have been updated based on recent experiments conducted on the ice surface, including the photolysis of $\mathrm{NO}_{3}^{-}$for the two product channels $\mathrm{NO}_{2}+\mathrm{O}^{-}$(or $\mathrm{OH}$ ) and $\mathrm{NO}_{2}^{-}+\mathrm{O}$ (Chu and Anastasio, 2003; Dubowski et al., 2002), $\mathrm{H}_{2} \mathrm{O}_{2}$ (Chu and Anastasio, 2005), $\mathrm{NO}_{2}^{-}$(Chu and Anastasio, 2007), HONO and $\mathrm{H}_{2} \mathrm{ONO}^{+}$(Anastasio and Chu, 2009). These photolytic reactions also affect halogen activation by controlling aqueousphase $\mathrm{OH}$ and gas-phase $\mathrm{NO}_{\mathrm{x}}$ concentrations in the snowpack and the overlying atmosphere.

For programming the chemical reaction component in PHANTAS, we exploited the ASAD atmospheric chemistry integration package (Carver et al., 1997), to which some adaptations have been made such as expanded arrays to deal with larger numbers of reactants and products in each of the aqueous-phase reactions than in gas-phase reactions and the use of the Livermore Solver for Ordinary Differential Equations with general Sparse Jacobian matrix (LSODES) (Hindmarsh, 1983) for numerical integration.

\subsection{Actinic flux}

Actinic flux in the atmosphere is calculated with a twostream algorithm by using the Phodis model (Kylling et al., 1995), which has been incorporated to PHANTAS for online calculations. Here we assume a clear sky on $30 \mathrm{March}$ at $71^{\circ} \mathrm{N}$ with a total column ozone of 400 Dobson units, over the snow surface with a wavelength-independent albedo of 0.9 (Warren and Wiscombe, 1980). The actinic flux also penetrates the snowpack and is attenuated with depth. The rate of the attenuation depends most strongly on the amount of absorbing impurities such as soot, dust and organic chromophores (e.g., Warren and Wiscombe, 1980); in this work, the e-folding depth is assumed to be $7.5 \mathrm{~cm}$ based on direct field measurements and radiative transfer modeling for the Arctic snowpack reported previously (King and Simpson, 2001; Peterson et al., 2002; Qiu et al., 2002; Simpson et al., 2002; Reay et al., 2012). An exception to this simple 
approximation takes place near the top of the snowpack at large solar zenith angles where significant enhancement in the actinic flux can occur relative to ambient air above the snow surface (Abbatt et al., 2012). This is not addressed in the present study. Also known from field observations but neglected here is the wavelength dependence of light absorption within the snowpack which could arise from organic chromophores (King and Simpson, 2001; Beine et al., 2011).

\subsection{Dispersion of trace gases in the snowpack interstitial air (SIA)}

Under calm weather conditions, molecular diffusion is considered to be important in controlling the exchange rate of trace gases through the SIA (Albert and Shultz, 2002). To account for the mean distance over which air molecules must diffuse within the pore space of porous media, we employ an effective molecular diffusivity, $D_{\mathrm{g}, \mathrm{em}}$, which is the intrinsic molecular diffusivity in free air, $D_{\mathrm{g}, \mathrm{mol}}$, scaled by tortuosity, $\tau_{\mathrm{g}}$ (Bear, 1972):

$D_{\mathrm{g}, \mathrm{em}}=D_{\mathrm{g}, \mathrm{mol}} / \tau_{\mathrm{g}}$.

Here, $\tau_{\mathrm{g}}=2$ is adopted to represent polar snowpack (Albert and Shultz, 2002). For gaseous species of interest in this paper (i.e., species other than mercury compounds), the values of $D_{\mathrm{g}, \mathrm{mol}}$ are calculated by using an empirical method by Fuller et al. (1966, 1969). Part 2 of this study describes how $D_{\mathrm{g}, \mathrm{mol}}$ is calculated for mercury compounds (Toyota et al., 2014).

As wind speed increases, a form drag associated with micro-topography on the snow surface develops, leading to pressure perturbations along mean streamlines on the upwind and downwind sides of the obstacles (Cunningham and Waddington, 1993; Andreas, 1995). This also creates pressure gradients within the porous snowpack and thus the ventilation of air, called "wind pumping", according to Darcy's law (Colbeck, 1989; Cunningham and Waddington, 1993; Albert, 1996). As in the previous similar model study by Thomas et al. (2011), the wind-pumping effect is superimposed as an additional, effective diffusivity ( $D_{\mathrm{g} \text {, pump }}$ ) to the effective molecular diffusivity defined in Eq. (4), but here only where the flow regime in the ambient air is diagnosed to be aerodynamically rough $\left(R_{*}>2.5\right.$, where $R_{*}$ is the roughness Reynolds number, see Sect. 2.7), viz., at high wind speeds:

$D_{\mathrm{SIA}}=\left\{\begin{array}{lr}D_{\mathrm{g}, \mathrm{em}} & \left(R_{*} \leq 2.5\right) \\ D_{\mathrm{g}, \mathrm{em}}+D_{\mathrm{g}, \text { pump }}\left(R_{*}>2.5\right) .\end{array}\right.$

The total effective diffusivity ( $\left.D_{\text {SIA }}\right)$ thus calculated is assumed to represent $D_{\mathrm{g}, z}$ in Eq. (1) within the snowpack (see Table 1).

Major factors that control the wind pumping in the SIA include the micro-topographic shape of the snow surface, wind speed and direction against the structures, and permeability dictated by microphysical properties of the snowpack (Colbeck, 1989; Cunningham and Waddington, 1993). Cunningham and Waddington (1993) derived an analytical solution for the three-dimensional (3-D) in-snow ventilation field of wind pumping, in which they made a number of assumptions for mathematical simplicity. Here we use the vertical component of their analytical solution after making a minor modification with regard to a boundary condition (see Appendix A):

$D_{\mathrm{g}, \text { pump }}=\frac{\left|\bar{V}_{z}\right| \times \Delta z}{\phi}$,

where $\bar{V}_{z}$, taken from Eq. (A1) in Appendix A, is an average volume flux of ventilated air, $\Delta z$ is a spacing between two adjacent segments of the discretized vertical layers, and $\phi$ is the snowpack porosity defined already.

\subsection{Representation of liquid-like layer (LLL) in snowpack}

Although the nature of condensed-phase reactions in/on ice is not fully understood, the layers of disordered water molecules (called "quasi-liquid layer", or "liquid-like layer", LLL) certainly exist at the ice surface down to $T \sim 200 \mathrm{~K}$ and are likely to play a critical role as a site for heterogeneous reactions (Abbatt, 2003; Domine et al., 2008). As with a model study similar to ours by Thomas et al. (2011), we assume that in-snow condensed-phase reactions occur entirely within the LLL in contact with the SIA and that chemical species do not migrate into the solid ice portion of snow grains. Thus the volume fraction $\left(f_{\mathrm{q}}\right)$ of the LLL in the total condensate relates the concentrations of aqueous-phase species in the LLL $\left(C_{\mathrm{a}}\right)$ to their bulk concentrations in the whole ice $\left(C_{\mathrm{i}}\right)$ via

$C_{\mathrm{i}}=f_{\mathrm{q}} C_{\mathrm{a}}$.

Here, the LLL is broadly defined as an fluid entity that is supposed to exist uniformly on the ice surface, where the reactivity of dissolved constituents is assumed to be identical to that in true liquids or brine (the concentrated solution of seawater) free from the effects of interfacial chemistry.

The thickness of the surface disorder is likely to increase by the presence of ionic impurities in the ice and by exposure of some gaseous contaminants to the ice surface, as indicated experimentally and theoretically (e.g., Conklin and Bales, 1993; Elbaum et al., 1993; Wettlaufer, 1999; Döppenschmidt and Butt, 2000; Bluhm et al., 2002; Voss et al., 2005; McNeill et al., 2006). Above the eutectic point of an ionic solution of salt, its presence will significantly increase $f_{\mathrm{q}}$, where the solute concentrations in the LLL can be estimated as a function of temperature and bulk concentrations of ionic impurities (Koop et al., 2000; Cho et al., 2002). Here we employ a simple thermodynamic equation from Cho et al. (2002) to calculate $f_{\mathrm{q}}$ at arbitrary temperature and bulk concentrations of 
major ions in the snow grains (see Sect. 2.10 for our scenario assumed for the present model runs).

Our present approach neglects the presence of liquid-like entities that are occluded within solid ice and are thus virtually inaccessible to gases in the SIA. However, according to experimental evidence, impurities in snow can be located in veins and pockets at grain boundaries and within grains, being isolated from rapid multiphase reactions of our present interest (Domine et al., 2013; Bartels-Rausch et al., 2014). In this regard, our model calculates upper limits for the LLL volume involved actively in multiphase photochemical reactions within the snowpack. Errors in our estimation of the LLL volume may also arise from simplified assumptions (e.g., no precipitation of solid salts, ideal solution) in the Cho et al. (2002) equation and presently neglected (but largely unknown) contributions from various natural and anthropogenic organic compounds to the ice surface properties (e.g., Bluhm et al., 2002; Douglas et al., 2012; Voisin et al., 2012).

\subsection{Vertical diffusion of dissolved constituents in snowpack}

We assume that vertical diffusion takes place of all the constituents dissolved in the LLL as a mechanism for transferring them between the snow grains. In the surface-disorder layer on ice, water molecules and dissolved ions are certainly more mobile than those "locked" inside the solid matrix (e.g., Furukawa and Nada, 1997; Carignano et al., 2007; Gladich et al., 2011). Since a snowpack consists of snow grains quite often if not always sintered or in contact with neighboring grains, it seems reasonable to assume that the surface of the snow grains is largely connected throughout the snowpack in a topological sense. Thus, if dissolved impurities are located in the LLL entirely on each snow grain as presumed in our study, they should be subject to diffusion throughout the vertical layers of the snowpack at rates of the same order of magnitude as estimated for molecules and ions in the surface-disorder layer of a single ice grain.

As a rough approximation, the self-diffusion coefficient of supercooled water is assumed to represent molecular diffusivity $\left(D_{\mathrm{aq}, \mathrm{mol}}\right)$ and its temperature dependence for all the constituents dissolved in the LLL if it is thick enough to behave like a bulk liquid. For this, we use an empirical fit to the Vogel-Fulcher-Tammann equation by Smith and Kay (1999):

$D_{\text {aq, } \text { mol }}=D_{0} \exp \left[-E /\left(T-T_{0}\right)\right]$,

where $\quad D_{0}=3.06 \times 10^{-3} \mathrm{~cm}^{2} \mathrm{~s}^{-1}, \quad E=892 \mathrm{~K} \quad$ and $T_{0}=118 \mathrm{~K}$. This equation gives $D_{\mathrm{aq}, \mathrm{mol}}=1.3-9.8 \times$ $10^{-6} \mathrm{~cm}^{2} \mathrm{~s}^{-1}$ between $233-273 \mathrm{~K}$. However, owing to a "proximity effect" imposed by the underlying wall of solid ice, molecules and ions in the LLL will likely become less mobile than those in the bulk liquid phase of the same composition (Dash et al., 1995). This may indeed be the case in our simulated scenario where the diagnosed thickness of the LLL is as shallow as $0.556 \mathrm{~nm}$, according to the diameter of each snow grain at $0.3 \mathrm{~mm}$ (see Sect. 2.1) and $f_{\mathrm{q}}=1.11 \times 10^{-5}$ prescribed by the Cho et al. (2002) equation (Sect. 2.5) with the assumed concentrations of ionic impurities (mainly $\mathrm{Na}^{+}$and $\mathrm{Cl}^{-}$, see Table 3). Hence we scale down the diffusivity of constituents in the LLL by a factor of 10 from a value inferred from Eq. (8), based upon a molecular dynamics simulation by Carignano et al. (2007) on the movement of $\mathrm{Na}^{+}$and $\mathrm{Cl}^{-}$in the surface-disorder layer of ice at the thickness of $\sim 0.8 \mathrm{~nm}$. Finally, the concept of tortuosity $\left(\tau_{\mathrm{aq}}\right)$ is also applicable for estimating the effective vertical diffusivity ( $D_{\mathrm{LLL}}$ ) through the hypothetical LLL connections:

$D_{\mathrm{LLL}}=0.1 \times D_{\mathrm{aq}, \mathrm{mol}} / \tau_{\mathrm{aq}}$,

where the likely range of $\tau_{\text {aq }}$ for natural snow/firn is 23 (Wolff and Paren, 1984; Laird et al., 1999) and here we choose $\tau_{\mathrm{aq}}=2$ (which coincidentally is identical to $\tau_{\mathrm{g}}$ ).

\subsection{Vertical diffusion in the atmospheric boundary layer (ABL)}

For simulating the vertical transport of trace gases and aerosols in the atmosphere, turbulent diffusivity, $K(z)$, in the stably stratified $\mathrm{ABL}$ is diagnosed by an empirical formula in the following form (Brost and Wyngaard, 1978):

$K(z)=\kappa z u_{*}\left(1-z / Z_{\mathrm{ABL}}\right)^{1.5} \Phi_{\mathrm{H}}(\zeta)^{-1}$,

where $\kappa$ is the von Kármán constant $(=0.4), z$ is height above the snow surface, $u_{*}$ is friction velocity, $Z_{\mathrm{ABL}}$ is the depth of the turbulent $\mathrm{ABL}$, and $\Phi_{\mathrm{H}}(\zeta)$ is a stability correction term for the surface layer profile of turbulent heat transfer. Here we assume that the turbulent diffusivity is the same for heat and chemical tracers. To accommodate the equation towards conditions with strong static stability, we use an expression taken from Cheng and Brutsaert (2005), rather than from Businger et al. (1971) adopted in Brost and Wyngaard (1978), for calculating $\Phi_{\mathrm{H}}(\zeta)$ (see Eq. (S2) in Sect. S2 of the Supplement). Here, $\zeta=z / L$ with $L$ being the Obukhov length:

$L=-\frac{\rho_{\mathrm{air}} c_{p} u_{*}^{3} T_{\mathrm{S}}}{\kappa g F_{\mathrm{SH}}}$.

In Eq. (11), $\rho_{\text {air }}$ is the mass density of air, $c_{p}$ is the specific heat capacity of air at constant pressure, $g$ is the acceleration due to gravity, $T_{\mathrm{S}}$ is the surface air temperature (i.e., $253 \mathrm{~K}$ for all the model runs, see Sect. 2.10), and $F_{\mathrm{SH}}$ is a sensible heat flux at the surface. For relating the wind speed $\left(U_{\text {ref }}\right)$ at an arbitrary-chosen reference height $\left(z_{\text {ref }}\right)$ to $u_{*}$ (see below), we adopt a stability correction term for momentum, $\Phi_{M}(\zeta)$, also from Cheng and Brutsaert (2005) (see Eq. (S1) in Sect. S2 of the Supplement). Impacts of choosing different stability functions than those from Cheng and Brutsaert (2005) on the 
diagnosed profiles of $K(z)$ are briefly discussed in the Supplement (Sect. S2).

For diagnosing $Z_{\mathrm{ABL}}$, we use a formulation taken from Zilitinkevich and Esau (2003):

$$
Z_{\mathrm{ABL}}=C_{R} \frac{u_{*}}{f}\left(1+\frac{C_{R}^{2} C_{u N}}{C_{S}{ }^{2}} \frac{N}{f} \frac{C_{R}^{2}}{C_{S}^{2}} \frac{u_{*}}{f L}\right)^{-1 / 2},
$$

where $C_{R}=0.5, C_{u N}=0.56, C_{S}=1.0, f$ is the Coriolis parameter and $N(=\sqrt{g / \theta \cdot \partial \theta / \partial z}$, where $\theta$ is potential temperature) is the Brunt-Väisälä frequency in the free atmosphere above the turbulent $\mathrm{ABL}$. The observed range of $N$ over the Beaufort Sea during the Surface Heat Budget of the Arctic Ocean Experiment (SHEBA) was 0.016-0.046 s ${ }^{-1}$ (Steeneveld et al., 2007). Here we adopt $N=0.031 \mathrm{~s}^{-1}$ as a baseline for our model runs, while testing the lower-bound and upper-bound $N$ values from Steeneveld et al. (2007) in some sensitivity runs. The value of $f$ is calculated for the latitude of $71^{\circ} \mathrm{N}$.

We calculate the profile of $K(z)$ and its diurnal variations for prescribed values of $U_{\text {ref }}$ and $T_{\mathrm{s}}$ kept constant over time and of $F_{\mathrm{SH}}$ changing diurnally. The calculation starts from seeking a numerical solution for $u_{*}$ and $z_{0}$ that will satisfy

$$
\begin{aligned}
U_{\text {ref }} & =\int_{z_{0}}^{z_{\text {ref }}} \frac{u_{*}}{\kappa z} \Phi_{\mathrm{M}}\left(\frac{z}{L}\right) \mathrm{d} z \\
& =\frac{u_{*}}{\kappa}\left[\ln \frac{z_{\text {ref }}}{z_{0}}-\Psi_{\mathrm{M}}\left(\frac{z_{\text {ref }}}{L}\right)+\Psi_{\mathrm{M}}\left(\frac{z_{0}}{L}\right)\right],
\end{aligned}
$$

where $z_{0}$ is the aerodynamic roughness length. This approach is actually inconsistent with our formulation of $K(z)$, viz., Eq. (10), in that it ignores the multiplication factor $\left(1-z / Z_{\mathrm{ABL}}\right)^{1.5}$. But it is acceptable as long as $Z_{\mathrm{ABL}}$ is sufficiently larger than $z_{\text {ref. }} \Psi_{M}$ is an integral form of $\Phi_{M}$ obtained analytically by Cheng and Brutsaert (2005) (see Eq. (S3) in Sect. S2 of the Supplement). Similarly, Cheng and Brutsaert (2005) analytically derived an integral form of $\Phi_{\mathrm{H}}$, viz., $\Psi_{\mathrm{H}}$ (see Eq. (S4) in Sect. S2 of the Supplement), which is used later in Eq. (18). The value of $z_{0}$ is calculated according to Andreas et al. (2004b):

$z_{0}=\frac{0.135 v}{u_{*}}+0.035 \frac{u_{*}^{2}}{g}\left\{F \exp \left[-\left(\frac{u_{*}-0.18}{0.1}\right)^{2}\right]+1\right\}$,

where the empirical parameter $F=1$ adopted here has been fitted to micro-meteorological data from a tower on the Beaufort Sea ice floe during the SHEBA campaign (Andreas et al., 2004a). Based on an analysis of heat flux measurements at the same meteorological tower from the SHEBA (Persson et al., 2002, see Fig. 17a), we assign a highly simplified form of diurnal variations in $F_{\mathrm{SH}}$ (in $\mathrm{W} \mathrm{m}^{-2}$ ) over local solar time (LST, $t$ ) between $0-24 \mathrm{~h}$ :

$F_{\mathrm{SH}}=-5+4 \times \cos \left[\frac{(t-12) \pi}{12}\right]$.
This approximates the average diurnal variations in March 1998 for the SHEBA tower site.

For assigning $K(z)$ from Eq. (10) to discrete vertical segments in the model, we first calculate aerodynamic resistance $\left(r_{\mathrm{a}}\right)$ between the mid-levels of neighboring atmospheric layers by numerically integrating the inverse of $K(z)$ over $z$ :

$r_{\mathrm{a}, i}=\int_{z_{i-1}}^{z_{i}} K(z)^{-1} \mathrm{~d} z$

The inverse of these $r_{\mathrm{a}, i}$ values are then multiplied by the layer size $\left(z_{i}-z_{i-1}\right)$ to obtain the vertical diffusivity $K_{i}$ for model implementation:

$K_{i}=\left(z_{i}-z_{i-1}\right) r_{\mathrm{a}, i}{ }^{-1}$.

In the lowest layer of the model atmosphere (discretized at $1 \mathrm{~cm}$, see below), we may neglect $z / Z_{\mathrm{ABL}}(\ll 1)$ in Eq. (10) so that we can integrate $1 / K(z)$ analytically from the scalar roughness length $\left(z_{\mathrm{s}}\right)$ to the mid-level of the layer $\left(z_{1}=\right.$ $0.5 \mathrm{~cm})$ :

$$
\begin{aligned}
r_{\mathrm{a}, 1} & =\int_{z_{\mathrm{s}}}^{z_{1}} K(z)^{-1} \mathrm{~d} z \\
& \approx \frac{1}{\kappa u_{*}}\left[\ln \frac{z_{1}}{z_{\mathrm{s}}}-\Psi_{\mathrm{H}}\left(\frac{z_{1}}{L}\right)+\Psi_{\mathrm{H}}\left(\frac{z_{\mathrm{s}}}{L}\right)\right] .
\end{aligned}
$$

Here, $z_{\mathrm{s}}$ changes with the ratio between kinematic viscosity (v) of air and molecular diffusivity $\left(D_{\mathrm{g}, \mathrm{mol}}\right)$ of trace gases (viz., Schmidt number, $S c=v / D_{\mathrm{g}, \mathrm{mol}}$ ) and characteristics of turbulence dissipation in the interfacial sublayer (viz., roughness Reynolds number, $\left.R_{*}=u_{*} z_{0} / v\right)$ on the snow surface. Semi-empirical equations derived by Brutsaert (1975) for aerodynamically smooth $\left(R_{*} \leq 0.135\right)$ and $\operatorname{rough}\left(R_{*} \geq 2.5\right)$ surfaces are employed here to calculate $z_{\mathrm{s}}$ :

$z_{\mathrm{s}}=$

$\left\{\begin{array}{l}z_{0} \exp \left[-\kappa a_{\mathrm{v}}\left(13.6 S c^{2 / 3}-13.5 a_{\mathrm{v}}{ }^{-1}\right)\right]\left(R_{*} \leq 0.135\right) \\ z_{0} \exp \left[-\kappa a_{\mathrm{v}}\left(7.3 R_{*}{ }^{1 / 4} S c^{1 / 2}-5 a_{\mathrm{v}}{ }^{-1}\right)\right]\left(R_{*} \geq 2.5\right),\end{array}\right.$

where ${a_{\mathrm{v}}}^{-1}(=1)$ is the turbulent Schmidt number (the ratio between eddy viscosity and eddy diffusivity) under a statically neutral condition. To fill in the gap between $0.135 \leq$ $R_{*} \leq 2.5, z_{\mathrm{s}} / z_{0}$ is fitted to an empirical log-log function of $R_{*}$ in the same fashion as Andreas (1987):

$\ln \left(z_{\mathrm{s}} / z_{0}\right)=b_{0}+b_{1} \ln \left(R_{*}\right)$,

where

$$
\begin{aligned}
& b_{0}=-\kappa a_{\mathrm{v}}\left(4.27 S c^{2 / 3}+6.3 S c^{1 / 2}-7.67 a_{\mathrm{v}}^{-1}\right) \\
& b_{1}=\kappa a_{\mathrm{v}}\left(4.66 S c^{2 / 3}-3.14 S c^{1 / 2}-2.91 a_{\mathrm{v}}^{-1}\right) .
\end{aligned}
$$



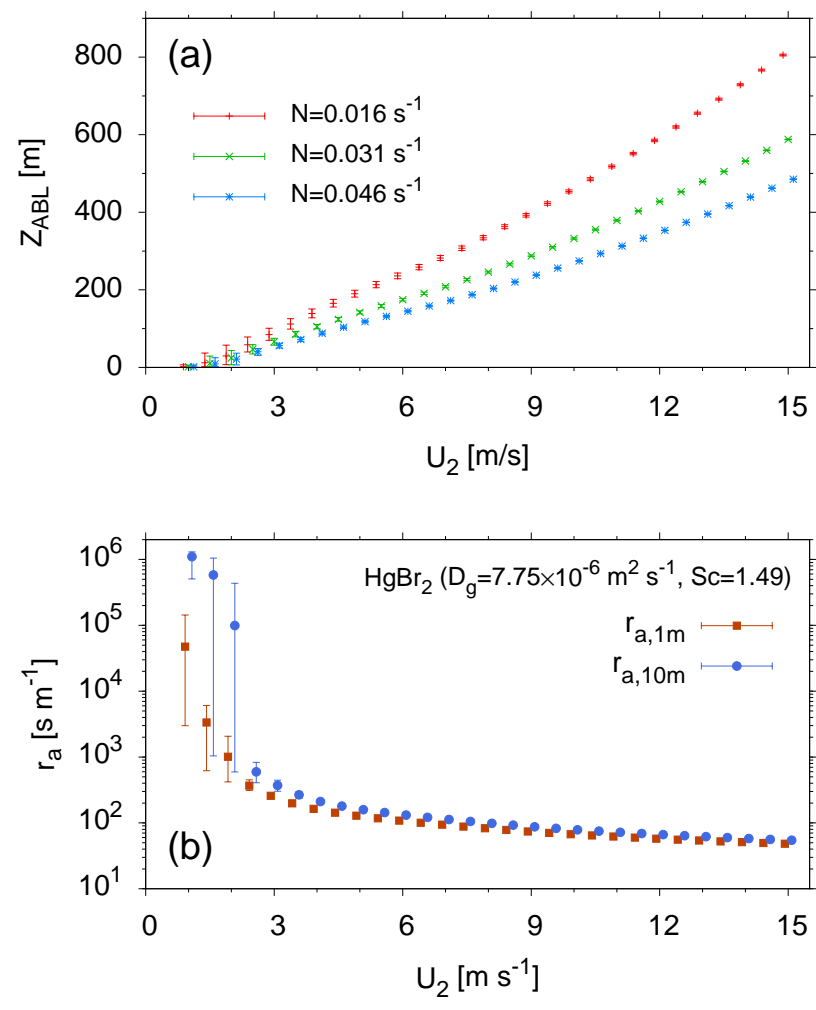

Fig. 2. (a) Changes in the diagnosed height of the turbulent atmospheric boundary layer $\left(Z_{\mathrm{ABL}}\right)$ with surface wind speeds $\left(U_{2}\right)$ between 1 and $15 \mathrm{~ms}^{-1}$ and Brunt-Väisälä frequencies in the free troposphere $(N)$ between 0.016 and $0.046 \mathrm{~s}^{-1}$. Cross marks denote daily mean values while bars indicate the range of diurnal variations; (b) aerodynamic resistance for $\mathrm{HgBr}_{2}$ from the snow surface to the height of either $1 \mathrm{~m}$ or $10 \mathrm{~m}$ in ambient air for $U_{2}=1-15 \mathrm{~m} \mathrm{~s}^{-1}$ at $N=0.031 \mathrm{~s}^{-1}$ as calculated in the present model. Filled squares and circles denote daily mean values while bars indicate the range of diurnal variations.

Aerodynamic resistance as estimated above already contains a contribution from quasi-laminar layer resistance (e.g., Garratt, 1992, Chap. 3.3.3), which is usually denoted as $r_{\mathrm{b}}$ and formulated independently from $r_{\mathrm{a}}$ when calculating dry deposition velocities of trace constituents. Figure $2 \mathrm{a}$ and $\mathrm{b}$ illustrate changes in $Z_{\mathrm{ABL}}$ and $r_{\mathrm{a}}$ (for $\mathrm{HgBr}_{2}$ at $1 \mathrm{~m}$ and $10 \mathrm{~m}$ above the snow surface), respectively, with different choices of $U_{\text {ref }}$ and $N$ in our algorithm. Since our model runs include cases where $Z_{\mathrm{ABL}}$ becomes lower than $10 \mathrm{~m}$ (but higher than $2 \mathrm{~m}$ ), $2 \mathrm{~m}$ is selected as our reference height, $z_{\text {ref. }}$

The model atmosphere is divided into 33 vertical layers with varying spacings: $1 \mathrm{~cm}$ (first layer), $9 \mathrm{~cm}$ (second layer), $90 \mathrm{~cm}$ (third layer) and then $1 \mathrm{~m}$ each up to a height of $10 \mathrm{~m}$ above the snow surface. The remaining 21 layers above $10 \mathrm{~m}$ height are evenly spaced, while the spacing is adjusted so that the top of the ABL at noon is located at the second highest model layer or below. Above $Z_{\mathrm{ABL}}$, vertical diffu- sivity is assumed to be controlled by molecular diffusion for gases and by Brownian diffusion for aerosols. We note that the diffusivity of chemical tracers in the real atmosphere will always be significantly greater than these theoretical lower bounds. This is because wind shear and the breaking of internal waves act as ubiquitous sources of turbulence even above the ABL (e.g., Blackadar, 1962; Mahrt, 2011). As a preliminary test, we conducted a sensitivity study in which the vertical diffusivity of gaseous and aerosol constituents $\left(D_{\mathrm{g}, z}\right.$ and $\left.D_{\mathrm{a}, \mathrm{z}}\right)$ were both raised to arbitrary values $\left(10^{-4}\right.$ $10^{0} \mathrm{~m}^{2} \mathrm{~s}^{-1}$ ) above the height of $Z_{\mathrm{ABL}}$. Its impact on simulated mixing ratios of ozone in the ABL became noticeable for $D_{\mathrm{g}, z}=D_{\mathrm{a}, \mathrm{z}} \geq 10^{-2} \mathrm{~m}^{2} \mathrm{~s}^{-1}$ above $Z_{\mathrm{ABL}}$ (not shown). Interestingly, Lagrangian models of plume chemistry and dispersion have indicated that the vertical diffusivity should be in the range of $0 \sim 1 \mathrm{~m}^{2} \mathrm{~s}^{-1}$ in the mid- to upper troposphere, albeit not in the context of chemistry in the lower troposphere of the polar region (Schumann et al., 1995; Pisso et al., 2009; Real et al., 2010). This certainly implies a possibility that our model results are affected by the diffusivity above the ABL under some circumstances, but the issue is beyond the scope of the present study.

For the derivation of $K(z)$ for each trace gas across the bottom atmospheric layer and the top snowpack layer, we add a contribution from aerodynamic resistance on the snowpack side $\left(=0.5 \Delta z / D_{\text {SIA }}\right)$ to Eq. (18). In order to describe the rates of air-snow exchange correctly across the discretized vertical layers for gases (e.g., $\mathrm{HOBr}$ ) subject to rapid heterogeneous reactions on the snow grains, the segment of the snowpack top layer has to be sufficiently small. In this study, $\Delta z=10^{-4} \mathrm{~m}$ is chosen for the topmost layer of snowpack and thus the extra aerodynamic resistance added to Eq. (18) is on the order of $10 \mathrm{~s} \mathrm{~m}^{-1}$ for each trace gas.

\subsection{Atmospheric aerosols}

Multiphase reactions involving aerosols can play a critical role in activating bromine chemistry by converting relatively stable $\mathrm{HBr}$ to photolabile $\mathrm{Br}_{2}$ in the atmosphere. In the springtime Arctic, "haze" aerosols of anthropogenic origin and made up mainly of sulfate in the sub- $\mu \mathrm{m}$ size range (e.g., Quinn et al., 2007) facilitate such reactions persistently in the ABL (Fan and Jacob, 1992). We neglect contributions from other types of aerosols, especially sea-salt aerosols, whose concentration can exceed that of the sulfate aerosols but only occasionally (Staebler et al., 1994; Yang et al., 2008). By this choice, we focus on situations in the Arctic ABL, rather than in the Antarctic ABL where "haze" aerosols essentially do not exist. As discussed in Part 2 of this study, aerosol chemistry also influences the gas-aerosol partitioning of oxidized mercury (Toyota et al., 2014).

Hygroscopic growth of aerosols that are composed of mixed $\mathrm{H}_{2} \mathrm{SO}_{4}-\mathrm{NH}_{4} \mathrm{HSO}_{4}$ solution is diagnosed by the Zdanovskii-Stokes-Robinson method (Zdanovskii, 1948; Stokes and Robinson, 1966), for which experimental data for 
the hygroscopic growth of single-electrolyte solutions (i.e., $\mathrm{H}_{2} \mathrm{SO}_{4}-\mathrm{H}_{2} \mathrm{O}$ and $\mathrm{NH}_{4} \mathrm{HSO}_{4}-\mathrm{H}_{2} \mathrm{O}$ ) at room temperature are taken from Tang and Munkelwitz (1994) and Tang (1996). For these calculations, we need to use relative humidity over liquid water, which is different from that over ice and is calculated here by the Goff (1957) equation (Murphy and Koop, 2005). For example, the relative humidity of $98 \%$ over ice (as assumed in our model runs) at $253 \mathrm{~K}$ and $1013.25 \mathrm{hPa}$ is translated to the relative humidity of $80.46 \%$ over liquid water. The density of the $\mathrm{H}_{2} \mathrm{SO}_{4}-\mathrm{NH}_{4} \mathrm{HSO}_{4}-\mathrm{H}_{2} \mathrm{O}$ mixture, used for the calculation of dry deposition velocity for aerosols, is obtained by a method described in Tang (1997).

At the beginning of each model run, aerosols are composed of $12 \mathrm{nmolm}^{-3}$ (STP) of $\mathrm{HSO}_{4}^{-}$and $\mathrm{SO}_{4}^{2-}$ and $9.6 \mathrm{nmol} \mathrm{m}^{-3}$ (STP) of $\mathrm{NH}_{4}^{+}$, typical concentrations in the Arctic lower troposphere during spring (e.g., Fisher et al., 2011). Under the temperature and humidity conditions stated above, the initial $\mathrm{pH}$ of aerosols is calculated to be -0.09 , in reasonable agreement with estimations from field observations in the Arctic boundary layer (Li, 1994; Staebler et al., 1999). The aerosols are then subject to compositional changes via chemical interactions with gas-phase species and irreversible loss from the atmosphere via dry deposition to the snow surface. For this purpose, we assume monodisperse aerosols with dry diameter of $0.25 \mu \mathrm{m}$, which is consistent with the geometric mean diameter of accumulation mode aerosols measured at Ny Ålesund in Spitsbergen during the spring of 1996 (Staebler et al., 1999). On the basis of a parameterization by Petroff and Zhang (2010), dry deposition velocities of sub- $\mu \mathrm{m}$ sulfate aerosols are calculated to be $\sim 0.02 \mathrm{~cm} \mathrm{~s}^{-1}$, determined primarily by poorly characterized phoretic effects on the snow surface.

One can distribute the deposited amount of aerosol composition among the top layers of the snowpack as simulated by Cunningham and Waddington (1993). They expanded a filter collection theory, which is normally used for estimating the ability of aerosol sampling techniques, to the calculation of in-snow filtration of aerosols along the streamlines of wind-pumping flow in the SIA. However, as noted by Harder et al. (1996), existing empirical formulas for the filtration efficiency (including the one employed by Cunningham and Waddington (1993)) only account for Brownian diffusion, impaction and interception of aerosols, whereas the phoretic effects, speculated as a major contributor to the dry deposition of aerosols on the snow by Petroff and Zhang (2010), are not incorporated into the formulations. Hence we choose to place the composition of deposited aerosols in the topmost layer of the snowpack as aqueous-phase species, which are then subject to vertical diffusion through (hypothetical) connections of the LLL across the snowpack layers (see Sect. 2.5). By this choice, the numerical implementation of mass transfer terms associated with the aerosol deposition is made much easier, as they fit in tri-diagonal matrices employed for diffusion terms (solved by an implicit Eu- ler method) and can thus be integrated altogether in a single solver (see Sect. 2.9).

\subsection{Operator splitting with a linear coupling between chemistry and transport terms}

The numerical integration of our governing equations, Eqs. (1)-(3), where diffusion and chemistry are acting simultaneously, is performed by using operator splitting. However, the nature of the problem addressed in this study poses a significant challenge. As mentioned in Sect. 2.7, the layer spacing at the top of the snowpack must be small enough to calculate aerodynamic resistance for gases correctly across the bottom layer of the atmosphere and the top layer of the snowpack. This constraint is particularly relevant to those gases which enter from the atmosphere and then interact rapidly with the snowpack LLL. For example, $\mathrm{Br}_{2}$ is produced via reactive uptake onto the LLL of gaseous $\mathrm{HOBr}$, which can either be transported via diffusion from the atmosphere or produced via gas-phase Reaction (R4) in the SIA. To avoid the overshooting of $\mathrm{HOBr}$ from the atmosphere into the SIA while accounting for its chemical source (such as Reaction R4) and sink (such as Reaction R1) with sufficient accuracy, one may use a very short time step for the numerical integration. However, to handle the stiffness of differential equations for multiphase chemistry, our chemical solver is integrated by the LSODES, which is computationally too demanding to be executed many times at short time steps.

As a partial solution to this problem, we adapt each of the chemistry and diffusion solvers by loosely coupling between the two in a linearized fashion; the zeroth-order rates of chemical sources (as calculated in the chemistry solver) and diffusional gains (as calculated in the diffusion solver) and the first-order rate constants of chemical sinks (as calculated in the chemistry solver) and diffusional losses (as calculated in the diffusion solver) are passed along from one solver and taken into account as additional effects in another solver while the two solvers are executed sequentially via operator splitting (see Fig. S6 in the Supplement for a flow chart of our procedure). At each time step ( $\Delta t=15 \mathrm{~s}$ in our model runs), the numerical integration begins with the execution of the adapted diffusion solver, which accounts for information carried over from the previous execution of the adapted chemistry solver, viz., the zeroth-order rates for gross chemical production (including empirically parameterized in-snow emissions, $S_{g}$, in the cases of $\mathrm{HCHO}$ and $\mathrm{CH}_{3} \mathrm{CHO}$ ) and the first-order rate constants for gross chemical loss, in all the vertical layers for each constituent. The loss of aerosol particles from the atmosphere via dry deposition, which transfers their constituents to the snowpack, is also taken account in the adapted diffusion solver (see below). This is followed by the execution of the adapted chemistry solver, which accounts for information carried over from the adapted diffusion solver, viz., the zeroth-order rates and the first-order rate constants of transport-related gain and loss, respectively, for 
Table 2. Summary of meteorological and geographic conditions used in the model runs.

\begin{tabular}{lll}
\hline Parameter & Values & Reference \\
\hline Latitude & $71^{\circ} \mathrm{N}$ & \\
$\begin{array}{l}\text { Date } \\
\text { Total column ozone }\end{array}$ & $30 \mathrm{March}$ & \\
Temperature & $400 \mathrm{Dobson}$ unit & \\
$\begin{array}{l}\text { Pressure } \\
\text { Relative humidity with respect to ice }\end{array}$ & $253 \mathrm{~K}$ & \\
$\begin{array}{l}\text { Reference-height wind speed }\left(U_{2}\right) \\
\text { Sensible heat flux at the bottom of }\end{array}$ & $2,4.5,8.5{\mathrm{or} 12 \mathrm{~m} \mathrm{~s}^{-1}}^{\mathrm{a}}$ & Andreas et al. (2002) \\
the atmosphere $\left(F_{\mathrm{SH}}\right)$ & $-5 \pm 4 \mathrm{~W} \mathrm{~m}^{-2 \mathrm{~b}}$ & Persson et al. (2002) \\
$\begin{array}{l}\text { Brunt-Väisälä frequency in the free } \\
\text { atmosphere }(N)\end{array}$ & $0.031 \mathrm{~s}^{-1 \mathrm{c}}$ & Steeneveld et al. (2007) \\
\hline
\end{tabular}

a At $T=253 \mathrm{~K}$ and $p=1013.25 \mathrm{hPa}$, it is equivalent to relative humidity with respect to water at $80.46 \%$ (see Sect. 2.8).

$\mathrm{b}$ A sinusoidal function to represent diurnal variations is assigned by the present authors (see Eq. (15) in Sect. 2.7).

${ }^{\mathrm{c}}$ In Sect. 3.5, sensitivity runs are also performed by using the high and low ends $\left(0.046 \mathrm{~s}^{-1}\right.$ and $0.016 \mathrm{~s}^{-1}$, respectively) of the $N$ values inferred by Steeneveld et al. (2007).

all the constituents in each vertical layer. This sequence is iterated up to 200 times unless numerical solutions for all the tracer concentrations $\left(C_{\mathrm{g}}\right.$ and $\left.C_{\mathrm{a}}\right)$ from the two solvers converge within given criteria, for which the relative tolerance of $10^{-3}$ is chosen in our model runs. However, as described in the Supplement (see Sect. S3 and Fig. S7), this threshold is occasionally (about $0.1-1 \%$ of the time depending on model runs) not attained owing to computational compromises we made in coupling between the chemistry and diffusion solvers; nonetheless, a relaxed criterion with the relative tolerance of $10^{-2}$ is generally achieved. Also, mass conservation is not necessarily strict in our solver-coupling method (see Sect. S3 in the Supplement).

In the adapted diffusion solver, vertical diffusion equations coupled with linearized chemical source/sink terms are solved for gas-phase and aqueous-phase species by an implicit Euler method. It employs an inversion of tri-diagonal matrices associated with diffusion and linearized chemical sink terms by LU decomposition (Press et al., 1992). As noted in Sect. 2.8, aerosol particles transferred from the atmosphere via dry deposition are allocated to the LLL in the topmost segment of the snowpack layers. This represents a one-way mass transfer between two adjacent layers and thus can be incorporated into the tri-diagonal matrices of the solver. Consequently, in the adapted diffusion solver, vertical mass transfer via diffusion and aerosol dry deposition, linearized effects of chemical production and loss, and empirical in-snow emissions are taken in account simultaneously.

\subsection{Simulation scenarios}

In this study, we first examine the impact of changing reference-height wind speeds $\left(U_{2}=2,4.5,8.5\right.$ and $\left.12 \mathrm{~ms}^{-1}\right)$ on the buildup rate of bromine in the ABL through changes in the profiles of turbulent diffusivity (Sect. 3.1). To simplify the simulation of chemical processes and the interpre- tation of results, temperature, relative humidity, and pressure are all assumed to be constant with height. In all the model runs, we use the same temperature, $253 \mathrm{~K}$, at which key ionic species of our present interest such as $\mathrm{Cl}^{-}, \mathrm{Br}^{-}$ and $\mathrm{NO}_{3}^{-}$will remain dissolved in the liquid-like portion of snow grains rather than precipitate as solid salts (e.g., Koop et al., 2000; Dubowski et al., 2002; Chu and Anastasio, 2003). Also, at this temperature, the saline snowpack in the polar environment likely retains properties that lead to the active release of gaseous bromine to the atmosphere, although the reasons are not clearly understood (e.g., Tarasick and Bottenheim, 2002; Pöhler et al., 2010). The same is true for the snowpack in our model under conditions specified below but, of course, the behavior of the model can be characterized firmly. By neglecting changes in the relative humidity with height, the occurrence of cloud droplets and its consequences on halogen chemistry are also disregarded (cf. Piot and von Glasow, 2008). Table 2 summarizes meteorological and geographic conditions used in our model runs.

Table 3 gives an initial condition for condensed-phase chemistry in the snowpack. There are several ways by which the snowpack on sea ice retains seawater composition (Abbatt et al., 2012, and references therein). Here we simply adopt our initial concentration of $\mathrm{Cl}^{-}$from a rough estimation by Cho et al. (2002) for the purpose of their theoretical calculation of brine volume in saline snowpack; it is certainly not very different (within a factor of $\sim 3$ ) from median levels of concentrations measured in the uppermost snowpack layers from Arctic nearshore and coastal regions including snowpack on multi-year sea ice (Domine et al., 2004; Simpson et al., 2005; Jacobi et al., 2012; Krnavek et al., 2012), while being factors of $\sim 30$ and $\sim 170$ lower than median $\mathrm{Cl}^{-}$concentrations measured in a top few centimeters of snowpack on thick first-year sea ice and on refrozen leads, respectively, near Barrow, Alaska (Krnavek 
Table 3. Initial conditions for condensed-phase chemistry in the snowpack.

\begin{tabular}{|c|c|c|}
\hline Parameter & Initial value & Reference \\
\hline Bulk concentration of $\mathrm{Cl}^{-}$ & $70 \mu \mathrm{molL}^{-1}$ & Cho et al. (2002) \\
\hline Bulk concentration of $\mathrm{Br}^{-}$ & $\begin{array}{l}0.108 \mu \mathrm{molL}^{-1} \\
\left(=1 / 650 \times\left[\mathrm{Cl}^{-}\right]\right)\end{array}$ & see note ${ }^{\mathrm{a}}$ \\
\hline Bulk concentration of $\mathrm{NO}_{3}^{-}$ & $2 \mu \mathrm{molL}^{-1}$ & Grannas et al. (2007) \\
\hline Bulk concentration of $\mathrm{HCO}_{3}^{-}$(alkalinity) & 0 & see note ${ }^{b}$ \\
\hline Bulk concentration of $\mathrm{Na}^{+}$ & $72 \mu \mathrm{molL}^{-1}$ & \\
\hline $\mathrm{pH}$ in LLL & 4 & \\
\hline Volume fraction of LLL $\left(f_{\mathrm{q}}\right)$ & $1.11 \times 10^{-5}$ & see note ${ }^{c}$ \\
\hline
\end{tabular}

et al., 2012). Basically, we assume vertically uniform concentrations of dissolved in-snow constituents in the initial state of model runs. By this choice, we ignore much higher salinity often observed near the snowpack bottom on top of brine-covered, first-year sea ice (Eicken et al., 1994; Massom et al., 1998; Domine et al., 2004; Obbard et al., 2009). The initial concentration ratio between $\mathrm{Cl}^{-}$and $\mathrm{Br}^{-}$is set to the same as the ratio in seawater, although field observations suggest that deviation from this assumption takes place very often in the snowpack (Domine et al., 2004; Simpson et al., 2005; Jacobi et al., 2012; Krnavek et al., 2012). A sensitivity study is also performed in which the initial $\mathrm{Br}^{-}$ concentration is raised 10-fold within the top $1 \mathrm{~mm}$ of snowpack to explore the impact of bromine deposited back from the atmosphere during previous ODEs (Sect. 3.2). The initial $\mathrm{NO}_{3}^{-}$concentration is $2 \mu \mathrm{molL}{ }^{-1}$, which is again about the median of observed ranges in the Arctic snowpack (Grannas et al., 2007). According to the $\mathrm{Cl}^{-}$concentration as specified above, alkalinity originally contained in seawater should be $\sim 0.3 \mu \mathrm{molL}^{-1}$ and thus should have been titrated by $\mathrm{NO}_{3}^{-}$. Bulk solutions melted from Arctic snowfall and snowpack are moderately acidic in most cases during the springtime (Gjessing, 1977; Semb et al., 1984; Toom-Sauntry and Barrie, 2002; Douglas and Sturm, 2004). Hence the value of $\mathrm{pH}$ in the LLL is initially set to four; however, it evolves by chemical processing of the snowpack in the course of our 8-day model runs (Sect. 3.3).

Table 4 lists the initial mixing ratios (or concentrations) of key trace gases and aerosol composition. By referring to data compiled from previous field observations (e.g., Evans et al., 2003; Sander and Bottenheim, 2012), we have selected values that are deemed to be representative of air masses in the springtime Arctic lower troposphere under non-ODE conditions. These initial concentrations are also used as an upper boundary condition to maintain the concentrations of trace constituents in the free troposphere under the non-ODE conditions. The initial concentrations of aerosol $\mathrm{Br}^{-}$is set to zero in order to highlight the role of gaseous bromine release from the snowpack. The mixing ratio of $\mathrm{CHBr}_{3}$ is fixed constant at $3.5 \mathrm{pmol} \mathrm{mol}^{-1}$ in the atmosphere and the SIA (e.g., Yokouchi et al., 1994). However, in contrast to a box model run by Tang and McConnell (1996), a contribution from the photolysis of $\mathrm{CHBr}_{3}$ is negligible even as a trigger to overall bromine activation in our model runs. Among the chemical species interacting strongly with bromine in the gas phase, $\mathrm{NO}_{\mathrm{x}}$ originates primarily from the photolysis of $\mathrm{NO}_{3}^{-}$in the model snowpack. Photochemical production of $\mathrm{HCHO}$ and $\mathrm{CH}_{3} \mathrm{CHO}$ (key scavengers of Br-atom) occurs via poorly understood condensed-phase reactions in the snowpack (e.g., Grannas et al., 2004), hence this process is empirically represented by an external source term, viz., $S_{g}$ in Eq. (1), at the rates changing vertically and diurnally within the SIA (Table 5).

Starting at 00:00 LST, all the model runs are continued for 8 days with the same diurnal variations in actinic fluxes and vertical diffusivity profiles. Chemical interactions of mercury with bromine and a few other reactants are also simulated in the present model runs (Toyota et al., 2014, see Sect. 2.3), but mercury species are not abundant enough to provide a notable feedback to the chemistry of bromine and ozone simulated here.

\section{Results and discussion}

\subsection{Impact of changing top height and turbulent diffusivity in the $\mathrm{ABL}$}

Since turbulent diffusivity in the ABL is constrained by the same values of diurnally varying sensible heat flux, the reference-height wind speed is a primary parameter that gives changes in the vertical extent of simulated buildup of reactive bromine and resultant ozone depletion between our model runs. Figure 3 shows the profiles of vertical diffusivity in the atmosphere from model runs at $U_{2}=2 \mathrm{~ms}^{-1}$, 
Table 4. Initial and upper boundary conditions for key trace gases (in both the atmosphere and the SIA) and aerosol composition.

\begin{tabular}{|c|c|}
\hline \multicolumn{2}{|c|}{ Gas-phase species ${ }^{\mathrm{a}}$} \\
\hline Species & Mixing ratio \\
\hline $\mathrm{O}_{3}$ & $40 \mathrm{nmolmol}^{-1}$ \\
\hline $\mathrm{H}_{2} \mathrm{O}_{2}$ & $250 \mathrm{pmol} \mathrm{mol}^{-1}$ \\
\hline $\mathrm{NO}_{2}$ & $15 \mathrm{pmol} \mathrm{mol}^{-1}$ \\
\hline $\mathrm{HNO}_{3}$ & $100 \mathrm{pmol} \mathrm{mol}^{-1}$ \\
\hline PAN & $200 \mathrm{pmol} \mathrm{mol}^{-1}$ \\
\hline $\mathrm{CH}_{4}$ & $1.85 \mu \mathrm{mol} \mathrm{mol}^{-1}$ \\
\hline $\mathrm{C}_{2} \mathrm{H}_{6}$ & $1.7 \mathrm{nmol} \mathrm{mol}^{-1}$ \\
\hline $\mathrm{C}_{2} \mathrm{H}_{2}$ & $400 \mathrm{pmol} \mathrm{mol}^{-1}$ \\
\hline $\mathrm{CO}$ & $150 \mathrm{nmolmol}^{-1}$ \\
\hline $\mathrm{HCHO}$ & $150 \mathrm{pmol} \mathrm{mol}^{-1 \mathrm{~b}}$ \\
\hline $\mathrm{CH}_{3} \mathrm{CHO}$ & $50 \mathrm{pmol} \mathrm{mol}^{-1 \mathrm{~b}}$ \\
\hline $\mathrm{CH}_{3} \mathrm{OOH}$ & $250 \mathrm{pmol} \mathrm{mol}^{-1}$ \\
\hline $\mathrm{CHBr}_{3}$ & $3.5 \mathrm{pmol} \mathrm{mol}^{-1}$ (fixed) \\
\hline $\mathrm{HCl}$ & $100 \mathrm{pmol} \mathrm{mol}^{-1}$ \\
\hline $\mathrm{SO}_{2}$ & $100 \mathrm{pmol} \mathrm{mol}^{-1}$ \\
\hline $\mathrm{CO}_{2}$ & $380 \mu \mathrm{mol} \mathrm{mol}^{-1}$ (fixed) \\
\hline \multicolumn{2}{|c|}{ Aerosol composition ${ }^{c}$} \\
\hline Species & Concentration \\
\hline $\mathrm{HSO}_{4}^{-}+\mathrm{SO}_{4}^{2-}$ & $12 \mathrm{nmol} \mathrm{m}^{-3}(\mathrm{STP})$ \\
\hline $\mathrm{NH}_{4}^{+}$ & $9.6 \mathrm{nmol} \mathrm{m}^{-3}(\mathrm{STP})$ \\
\hline $\mathrm{Cl}^{-}{ }^{4}$ & 0 \\
\hline $\mathrm{Br}^{-}$ & 0 \\
\hline $\mathrm{pH}$ & $\sim-0.09$ \\
\hline
\end{tabular}

a Initial mixing ratios for gas-phase species are selected on the basis of observational data compilations (Evans et al., 2003; Sander and Bottenheim, 2012, and references therein).

b To start model runs with the concentrations of $\mathrm{HCHO}$ and $\mathrm{CH}_{3} \mathrm{CHO}$ closer to their near-steady-state conditions constrained strongly by empirical in-snow emissions, their initial concentrations in the SIA are raised by a factor of two. Furthermore, the initial concentrations of their dissolved forms (including hydrate) in the LLL are set in thermodynamic equilibria with the concentrations of respective gases in the SIA.

${ }^{c}$ See Sect. 2.8 for details on initial sulfate and ammonium concentrations and aerosol $\mathrm{pH}$.

Table 5. Empirical in-snow emissions for $\mathrm{HCHO}$ and $\mathrm{CH}_{3} \mathrm{CHO}$.

\begin{tabular}{lll}
\hline Species & Emission rate $^{\mathrm{a}}$ & Reference \\
\hline $\mathrm{HCHO}$ & $4.8 \times 10^{8}$ molecule $\mathrm{cm}^{-2} \mathrm{~s}^{-1}$ & Grannas et al. (2002) \\
$\mathrm{CH}_{3} \mathrm{CHO}$ & $4.25 \times 10^{8}$ molecule $\mathrm{cm}^{-2} \mathrm{~s}^{-1}$ & Guimbaud et al. (2002)
\end{tabular}

${ }^{a}$ Vertically integrated and diurnally averaged in-snow emission rates are given here. During model runs, the emission rates are scaled in time and in space according to $J$ values for $\mathrm{O}_{3}+h v \rightarrow \mathrm{O}\left({ }^{1} \mathrm{D}\right)+\mathrm{O}_{2}$.

$4.5 \mathrm{~m} \mathrm{~s}^{-1}$ and $8.5 \mathrm{~ms}^{-1}$. In all cases, the prescribed values of the diffusivity maximizes at local noon because of the smallest cooling rate at the surface $\left(F_{\mathrm{SH}}=-1 \mathrm{~W} \mathrm{~m}^{-2}\right)$, while the maximum values in the middle of the turbulent ABL change by more than an order of magnitude between the model runs.
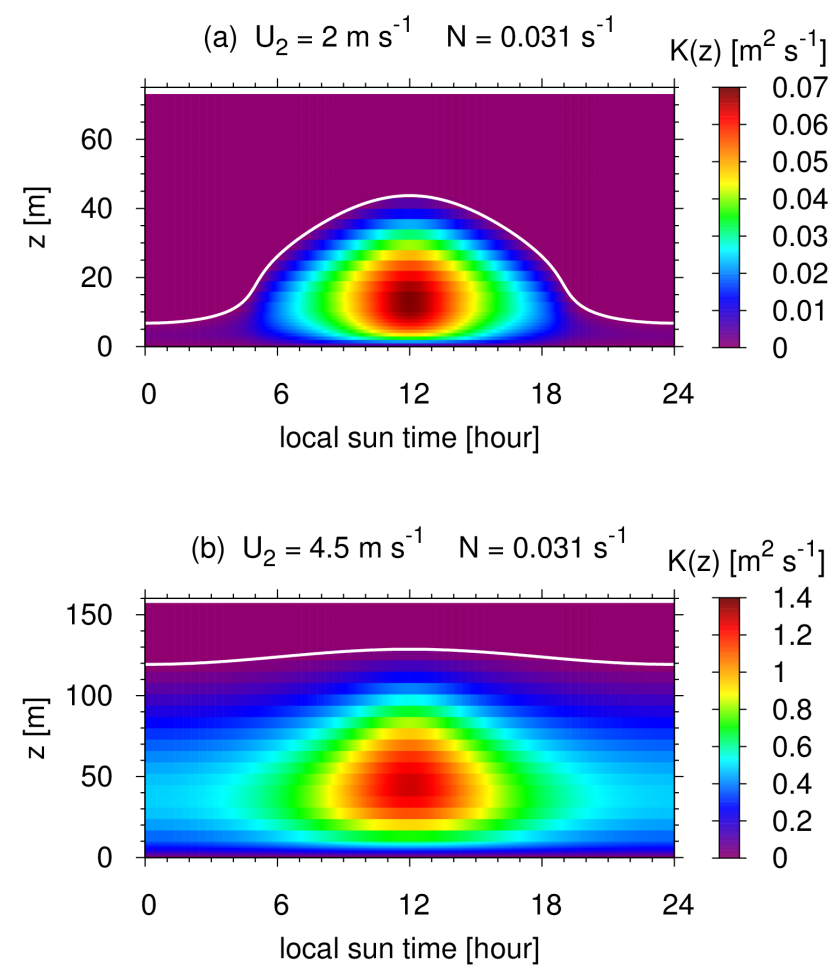

(c) $\mathrm{U}_{2}=8.5 \mathrm{~m} \mathrm{~s}^{-1} \quad \mathrm{~N}=0.031 \mathrm{~s}^{-1} \quad \mathrm{~K}(\mathrm{z})\left[\mathrm{m}^{2} \mathrm{~s}^{-1}\right]$

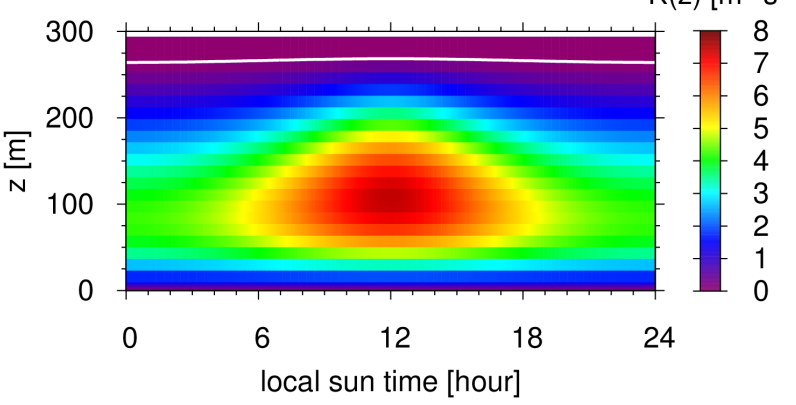

Fig. 3. Profiles and their diurnal variations of vertical diffusivity in the atmosphere prescribed by assuming $N=0.031 \mathrm{~s}^{-1}$ and $U_{2}=2 \mathrm{~ms}^{-1}$ (a), $4.5 \mathrm{~ms}^{-1}$ (b) and $8.5 \mathrm{~ms}^{-1}$ (c). The white line in each graph indicates the level of $Z_{\mathrm{ABL}}$, above which the vertical diffusion is assumed to be controlled by molecular diffusion for gases or by Brownian diffusion for aerosols.

Also, the top height of the turbulent ABL changes significantly between day and night during calm weather conditions at $U_{2}=2 \mathrm{~m} \mathrm{~s}^{-1}$, whereas it does not at $U_{2}=4.5 \mathrm{~m} \mathrm{~s}^{-1}$ and $8.5 \mathrm{~m} \mathrm{~s}^{-1}$. Most importantly, noontime maximum for the top height of the ABL increases from $44 \mathrm{~m}$ at $U_{2}=2 \mathrm{~m} \mathrm{~s}^{-1}$ to $268 \mathrm{~m}$ at $U_{2}=8.5 \mathrm{~m} \mathrm{~s}^{-1}$.

As shown in Fig. $4 \mathrm{a}-\mathrm{c}$, the buildup of reactive bromine and thus the ozone depletion in the ABL takes place more swiftly as the reference-height wind speed decreases. At $U_{2}=2 \mathrm{~ms}^{-1}$, it takes only 2 days to decrease the ozone mixing ratio (initially $40 \mathrm{nmol} \mathrm{mol}^{-1}$ ) below $20 \mathrm{nmol} \mathrm{mol}^{-1}$, 
whereas, at $U_{2}=4.5 \mathrm{~m} \mathrm{~s}^{-1}$ and $8.5 \mathrm{~m} \mathrm{~s}^{-1}$, it takes more than 3 days and 4 days, respectively. This trend in timescale results from changes in the depth of the turbulent ABL. The shallower ABL accumulates snow-released material more rapidly. On the other hand, the decrease in the ABL depth comes with an increase in aerodynamic resistance in the nearsurface ambient air, thereby counteracting the trend of increasing buildup rate of reactive bromine with decreasing ABL depth. As indicated from Fig. 2b, the aerodynamic resistance of ambient air to the top of the snowpack is greater at $U_{2}=2 \mathrm{~m} \mathrm{~s}^{-1}$ by an order of magnitude (or more) than at $U_{2}=4.5 \mathrm{~m} \mathrm{~s}^{-1}$ and $8.5 \mathrm{~m} \mathrm{~s}^{-1}$. The magnitude of changes in the aerodynamic resistance thus exceeds that of the 6 -fold changes in the ABL depth noted above. This appears to be one of the major factors for the relatively small difference in the simulated timescale for the buildup of atmospheric bromine between model runs as compared to the changes in the ABL depth.

The accumulation of snow-sourced aldehydes, $\mathrm{HCHO}$ and $\mathrm{CH}_{3} \mathrm{CHO}$, is another important factor. These compounds are known to have a strong potential to terminate the recycling of bromine radicals by converting $\mathrm{Br}$-atom to $\mathrm{HBr}$ (Barrie et al., 1988; Bottenheim et al., 1990; Sander et al., 1997; Toyota et al., 2004):

$\mathrm{Br}+\mathrm{RCHO} \rightarrow \mathrm{HBr}+\mathrm{RCO}$,

where $\mathrm{R}=\mathrm{H}$ or $\mathrm{CH}_{3}$. Several mechanisms (physical adsorption/desorption on ice surface, hydrocarbon oxidation initiated by $\mathrm{Cl}$-atom, etc.) have been suggested to control the variability of aldehyde concentrations in the polar boundary layer, but the photochemical degradation of dissolved organics in the snow is definitely an important source (Grannas et al., 2007, and references therein). In our model runs, empirically adjusted in-snow emissions of $\mathrm{HCHO}$ and $\mathrm{CH}_{3} \mathrm{CHO}$ (see Sect. 2.10) are the predominant sources of these compounds in the entire model domain. Solid lines in Fig. 5a and $b$ show time series in the simulated mixing ratios of $\mathrm{HCHO}$ and $\mathrm{CH}_{3} \mathrm{CHO}$ and their changes with $U_{2}$ in ambient air at $1.5 \mathrm{~m}$ above the snowpack. At $U_{2}=2 \mathrm{~m} \mathrm{~s}^{-1}$, simulated mixing ratios for $\mathrm{HCHO}$ and $\mathrm{CH}_{3} \mathrm{CHO}$ in the ambient air reach over $300 \mathrm{pmol} \mathrm{mol}^{-1}$ and $200 \mathrm{pmol} \mathrm{mol}^{-1}$, respectively, more than a factor of two greater than the mixing ratios for respective species at $U_{2}=4.5 \mathrm{~m} \mathrm{~s}^{-1}$ and $8.5 \mathrm{~m} \mathrm{~s}^{-1}$. By impeding the bromine explosion across the ambient air and the snowpack (see Sect. 3.2), the higher levels of aldehydes simulated at lower wind speeds not only decelerate the buildup rates of reactive bromine in the ABL (albeit not as much as overriding the faster accumulation of snow-sourced bromine in the shallower ABL, see Fig. 5c) but also raise the steady-state mixing ratios of ozone after the maturity of ODEs (Fig. 5e). At $U_{2}=2 \mathrm{~m} \mathrm{~s}^{-1}$, decrease in the ozone mixing ratio stops at $\sim 10 \mathrm{nmolmol}^{-1}$, whereas, at higher wind speeds, it can continue until ozone levels drop below $5 \mathrm{nmol} \mathrm{mol}^{-1}$.
Simulated maxima for the atmospheric mixing ratio of HCHO shown in Fig. 5a are all within the range of field measurements in the springtime Arctic, but the mixing ratios of $\mathrm{CH}_{3} \mathrm{CHO}$ as high as $500 \mathrm{pmol} \mathrm{mol}^{-1}$ simulated at $U_{2}=2 \mathrm{~m} \mathrm{~s}^{-1}$ after ozone is depleted (see Fig. 5b) well exceed reported maxima $\left(\sim 300 \mathrm{pmol} \mathrm{mol}^{-1}\right)$ of field data (e.g., Boudries et al., 2002; Grannas et al., 2002; Guimbaud et al., 2002). If those field measurements were free from instrumental artifacts and also if the data sampled a sufficiently broad range of environmental conditions, then there should be an important sink for $\mathrm{CH}_{3} \mathrm{CHO}$ missing in our chemical scheme (e.g., Domine et al., 2010) or perhaps our choice for the in-snow emission rate of $\mathrm{CH}_{3} \mathrm{CHO}$ may have been too high. Hence, by decreasing this ad hoc parameter 5fold to $8.5 \times 10^{7}$ molecule $\mathrm{cm}^{-2} \mathrm{~s}^{-1}$, we looked at a sensitivity of simulated results to the $\mathrm{CH}_{3} \mathrm{CHO}$ levels (dotted lines in Fig. 5a-e). In this case, the model does not simulate higher than $100 \mathrm{pmol} \mathrm{mol}^{-1}$ for the atmospheric mixing ratio of $\mathrm{CH}_{3} \mathrm{CHO}$ in any runs (Fig. 5b). Consequently, reactive bromine species accumulate at faster rates in the atmosphere and also reach higher levels in the course of their buildup (Fig. 5c). At $U_{2}=2 \mathrm{~m} \mathrm{~s}^{-1}$, the ozone mixing ratio drops from the initial level of $40 \mathrm{nmol} \mathrm{mol}^{-1}$ to lower than $20 \mathrm{nmol} \mathrm{mol}^{-1}$ in a day and half $(\sim 1$ day shorter than in the model run with the default rate of in-snow $\mathrm{CH}_{3} \mathrm{CHO}$ emissions). Also, the minimum mixing ratios of ozone reached on the maturity of ODEs become lower by using the lower rate of in-snow $\mathrm{CH}_{3} \mathrm{CHO}$ emissions, as is particularly evident at $U_{2}=2 \mathrm{~ms}^{-1}$ (Fig. 5e).

$\mathrm{NO}_{\mathrm{x}}\left(=\mathrm{NO}+\mathrm{NO}_{2}\right)$, being supplied from the in-snow source originating from $\mathrm{NO}_{3}^{-}$photolysis, is simulated to drop its mixing ratios significantly during the buildup of reactive bromine in the $\mathrm{ABL}$ where high $\mathrm{BrO}$ mixing ratios are maintained (Fig. $5 \mathrm{c}$ and d). This results from a formation of $\mathrm{BrONO}_{2}$ followed mostly by its hydrolysis on aerosols (e.g., Evans et al., 2003):

$$
\begin{aligned}
& \mathrm{BrO}+\mathrm{NO}_{2}+\mathrm{M} \rightarrow \mathrm{BrONO}_{2}+\mathrm{M} \\
& \mathrm{BrONO}_{2}+\mathrm{H}_{2} \mathrm{O}_{\mathrm{aq}} \rightarrow \mathrm{HOBr}+\mathrm{HNO}_{3} .
\end{aligned}
$$

Once ozone is depleted from the atmosphere, the mixing ratios of $\mathrm{BrO}$ drop significantly as it makes up a negligible fraction in the partitioning of inorganic bromine without an adequate supply via Reaction (R3). At that point, $\mathrm{NO}_{\mathrm{x}}$ levels in the ABL start to recover towards their new steadystate mixing ratios of about 10 to $60 \mathrm{pmol} \mathrm{mol}^{-1}$. In model runs with the lower rate of in-snow $\mathrm{CH}_{3} \mathrm{CHO}$ emissions at $8.5 \times 10^{7}$ molecule $\mathrm{cm}^{-2} \mathrm{~s}^{-1}$, it is evident that $\mathrm{NO}_{\mathrm{x}}$ being sourced from the snowpack reaches higher mixing ratios in the near-surface ambient air under less turbulent conditions at lower wind speeds. This trend is not obvious as much in model runs with the default rate of in-snow $\mathrm{CH}_{3} \mathrm{CHO}$ emissions, because, in this case, there is a trade-off arising from a formation of peroxyacetyl nitrate $\left(\mathrm{PAN}, \mathrm{CH}_{3} \mathrm{C}(\mathrm{O}) \mathrm{O}_{2} \mathrm{NO}_{2}\right.$ ) to scavenge $\mathrm{NO}_{2}$ from the ABL under more stable conditions with higher $\mathrm{CH}_{3} \mathrm{CHO}$ levels. Scrutinizing the simulated 
(a) $\mathrm{U}_{2}=2 \mathrm{~m} \mathrm{~s}^{-1}$
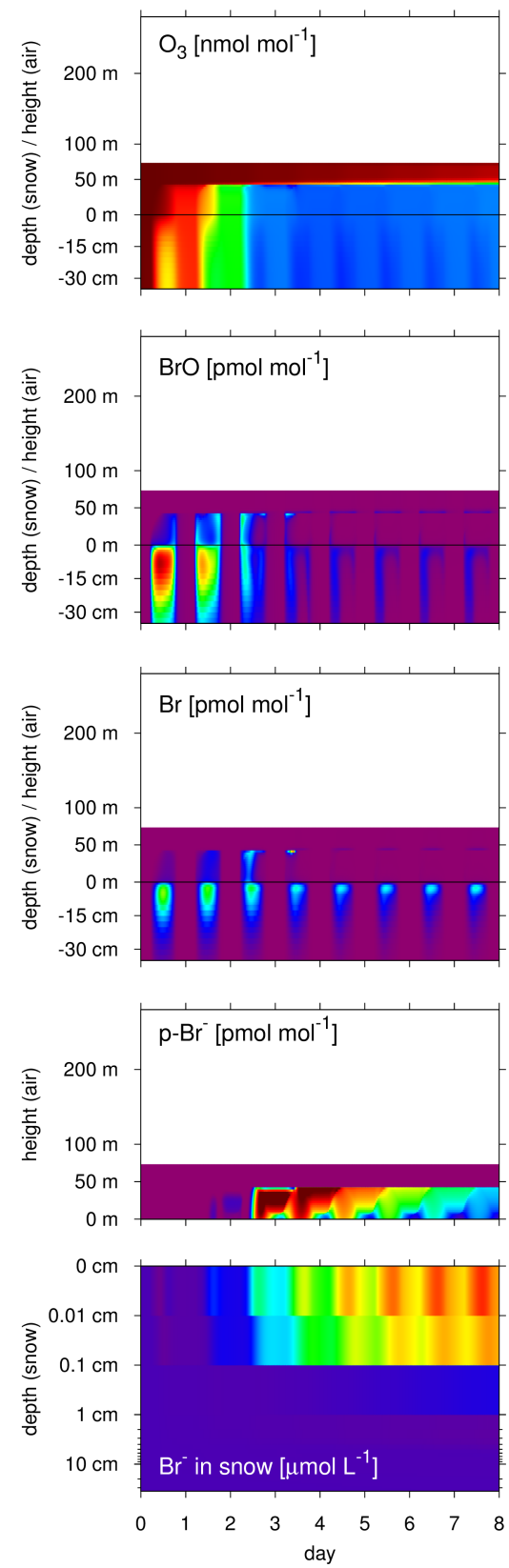

(b) $\mathrm{U}_{2}=4.5 \mathrm{~m} \mathrm{~s}^{-1}$
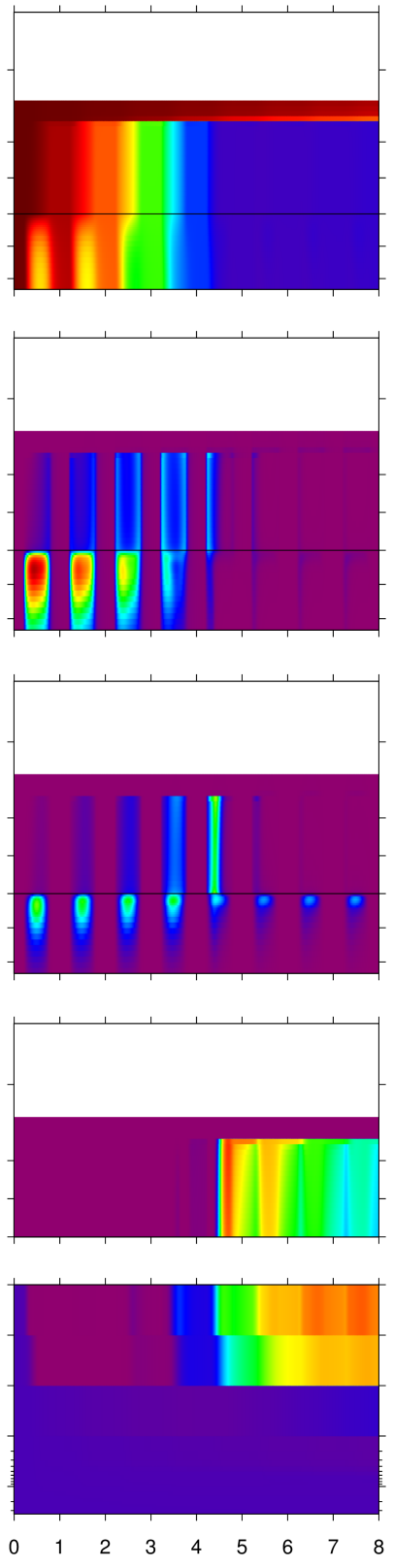

(c) $\mathrm{U}_{2}=8.5 \mathrm{~m} \mathrm{~s}^{-1}$
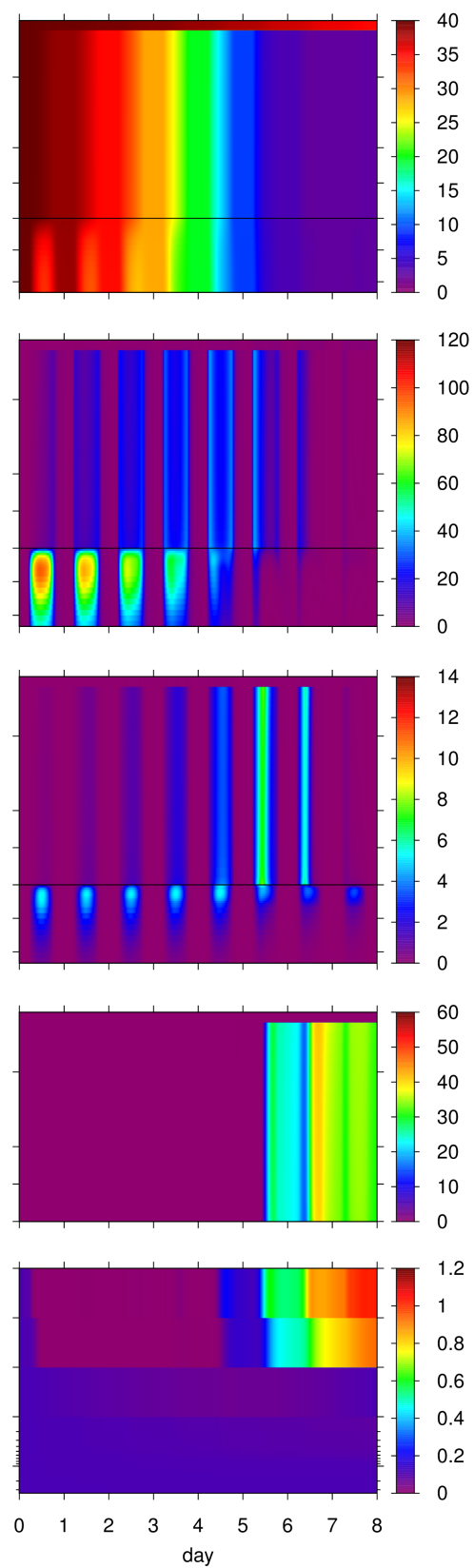

Fig. 4. Time-height cross sections for the mixing ratios of $\mathrm{O}_{3}$ (top row), $\mathrm{BrO}$ (second row), $\mathrm{Br}$-atom (third row), and aerosol bromide (p-Br ${ }^{-}$, fourth row), and for the bulk concentrations of bromide in snowpack grains (bottom row) from model runs with $U_{2}=2 \mathrm{~m} \mathrm{~s}^{-1}$ (a), $4.5 \mathrm{~ms} \mathrm{~s}^{-1}$ (b), and $8.5 \mathrm{~ms}^{-1}$ (c). $N=0.031 \mathrm{~s}^{-1}$ for all the model runs.

behavior of PAN against that of $\mathrm{NO}_{\mathrm{x}}$ could provide an indirect means to evaluate whether the correct range of source strengths is assigned for $\mathrm{CH}_{3} \mathrm{CHO}$ in the model (e.g., Evans et al., 2003), but this is beyond our present scope. Owing to relatively high $\mathrm{NO}_{\mathrm{x}}$ mixing ratios simulated after the maturity of ODEs, the model run at $U_{2}=2 \mathrm{~ms}^{-1}$ and with the lower rate of in-snow $\mathrm{CH}_{3} \mathrm{CHO}$ emissions exhibits a notable recovery of ozone by its net photochemical produc- tion via $\mathrm{NO}_{\mathrm{x}}$ chemistry after reaching the minimum level of $\sim 1 \mathrm{nmol} \mathrm{mol}^{-1}$ on day 3 to $\sim 7 \mathrm{nmol} \mathrm{mol}^{-1}$ near the end of day 8 (Fig. 5e).

To summarize the sensitivity experiments presented in this subsection, in the statically stable ABL prevalent in the springtime Arctic, the likelihood is expected to become higher at lower wind speeds for air masses to experience ozone mixing ratios below $10 \mathrm{nmol} \mathrm{mol}^{-1}$ persistently. 

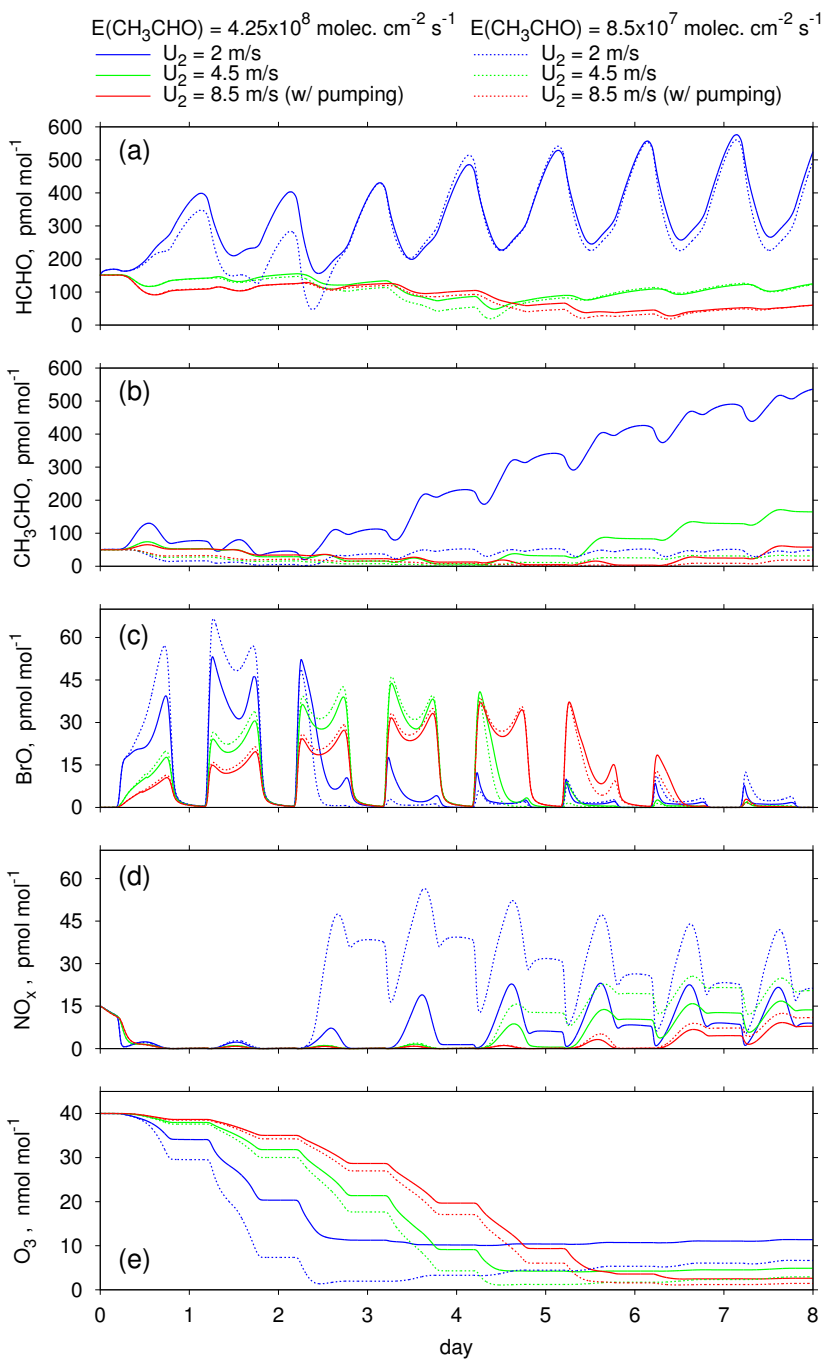

Fig. 5. Simulated mixing ratios of (a) $\mathrm{HCHO}$, (b) $\mathrm{CH}_{3} \mathrm{CHO}$, (c) $\mathrm{BrO}$, (d) $\mathrm{NO}_{\mathrm{x}}\left(=\mathrm{NO}+\mathrm{NO}_{2}\right.$ ), and (e) $\mathrm{O}_{3}$ at $z=1.5 \mathrm{~m}$ (ambient air) from model runs with snowpack emissions of $\mathrm{CH}_{3} \mathrm{CHO}$ at "standard" (solid lines) and "low" (dotted lines) rates and with $U_{2}$ assigned at either $2 \mathrm{~m} \mathrm{~s}^{-1}$ (blue), $4.5 \mathrm{~m} \mathrm{~s}^{-1}$ (green), or $8.5 \mathrm{~m} \mathrm{~s}^{-1}$ (red).

Surface ozone measurements at a coastal site, Barrow $\left(71^{\circ} \mathrm{N}\right)$ in Alaska, showed the occurrence of ODEs mainly in air masses from the ice-covered ocean and locally at low wind speed conditions (Johnson et al., 2008; Helmig et al., 2012), in line with our finding from model simulations. On the other hand, from the analyses of surface ozone data obtained over the frozen Arctic Ocean, some studies highlighted the role of ozone supply, occurring especially under windy conditions, by the transport of air masses not in recent contact with sea ice in raising otherwise very low ozone levels (e.g., Bottenheim et al., 2009; Jacobi et al., 2010; Moore et al., 2014). Here we stress that calm weather conditions should not only decrease chances for such an ozone supply but also facilitate the buildup of reactive bromine, leading to more rapid and persistent depletion of ozone especially in the Arctic ABL, where "haze" aerosols continuously mediate the heterogeneous recycling of inorganic bromine species unlike in the Antarctic ABL. The present study corroborates findings from earlier studies employing much simpler modeling frameworks in regard to the relationships between timescale to accumulate snow-sourced bromine involved in ODEs and turbulence in the ABL (Lehrer et al., 2004; Jones et al., 2009). However, by using a more comprehensive modeling approach, we also find a few trade-off factors associated with correlations in turbulence strength and the depth of the ABL and with photochemical interactions between bromine, aldehydes and nitrogen oxides that are all released from the snowpack. The photochemical trade-off is expected to become particularly important under calm weather conditions, warranting continued efforts to understand what controls the behaviors of aldehydes and nitrogen oxides on the snow for a better characterization of bromine chemistry in the polar boundary layer. Although not addressed in this study, low-molecular weight alkenes, formed presumably via condensed-phase photochemistry along with aldehydes and released from the polar snowpack (e.g., Bottenheim et al., 2002), may also warrant a close look, as they are likely to impede the bromine explosion by converting $\mathrm{Br}$-atoms into brominated organic intermediates (e.g., Sander et al., 1997; Toyota et al., 2004; Keil and Shepson, 2006).

\subsection{Bromine explosion in the coupled atmosphere-snowpack system}

As shown in Fig. 4a-c by a stark contrast in the simulated mixing ratios of $\mathrm{BrO}$ and $\mathrm{Br}$-atom between SIA and the overlying ambient air, bromine radical chemistry is substantially more active in the SIA. Thus, ozone loss occurs more rapidly in the SIA via catalytic reactions involving Reactions (R3) and (R11):

$\mathrm{BrO}+\mathrm{BrO} \rightarrow 2 \mathrm{Br}+\mathrm{O}_{2}$,

leading to notably lower (up to $\sim 10 \mathrm{nmol} \mathrm{mol}^{-1}$ ) ozone mixing ratio in the SIA during sunlit hours. Figure $6 \mathrm{a}$ and $\mathrm{b}$ show a contrast in the partitioning of bromine species between the ambient air ( $1.5 \mathrm{~m}$ above the snow) and the SIA ( $3.5 \mathrm{~cm}$ below the top of the snowpack). $\mathrm{BrNO}_{2}$ and $\mathrm{BrONO}_{2}$ are simulated to maintain relatively low mixing ratios $\left(<2 \mathrm{pmol} \mathrm{mol}^{-1}\right)$ and are therefore omitted from these plots. In the ambient air, $\mathrm{BrO}$ is the most abundant bromine species during the daytime, reaching as high as $40 \mathrm{pmol} \mathrm{mol}^{-1}$ as has been measured in the field (e.g., Pöhler et al., 2010; Liao et al., 2011), until the ozone mixing ratio drops below $\sim 10 \mathrm{nmol} \mathrm{mol}^{-1}$ on day 5 . Before the depletion of ozone, daytime gas-phase chemistry actively produces $\mathrm{HOBr}$ and $\mathrm{HBr}$, which are then taken up onto sulfate aerosols to give $\mathrm{Br}_{2}$ via Reaction (R1). $\mathrm{Br}_{2}$ is rapidly photolyzed via Reaction (R2) and thus makes an important contribution to raising the bromine radical concentrations (Fan and Jacob, 

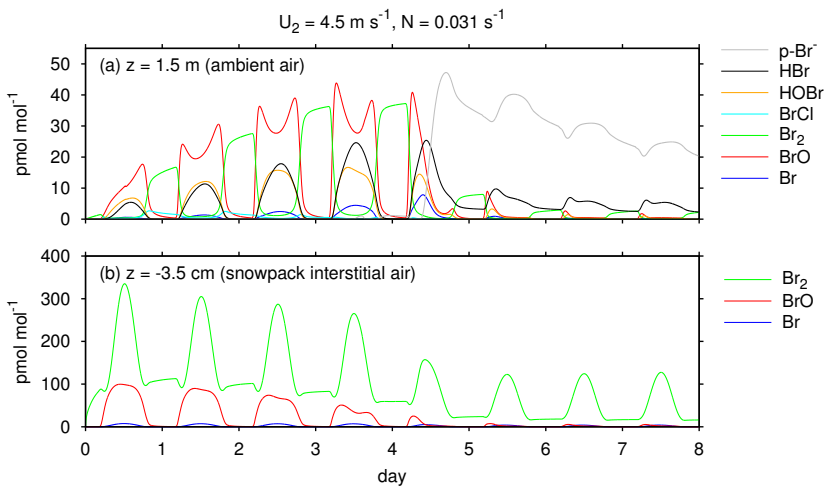

Fig. 6. Temporal evolution of major bromine species at the height of (a) $z=1.5 \mathrm{~m}$ (ambient air) and (b) $z=-3.5 \mathrm{~cm}$ (snowpack interstitial air) from a model run with $U_{2}=4.5 \mathrm{~m} \mathrm{~s}^{-1}$ and $N=0.031 \mathrm{~s}^{-1}$.

1992). In contrast, $\mathrm{Br}_{2}$ simply accumulates at night in the ambient air and constitutes a predominant fraction among the inorganic bromine species. These partitioning patterns change as ozone is depleted with time. The daytime mixing ratios of $\mathrm{Br}$-atom increase with decreasing ozone mixing ratios, reaching $\sim 7 \mathrm{pmol} \mathrm{mol}^{-1}$ on day 5 . This trend in the $\mathrm{Br}$-atom concentrations against changes in the ozone concentrations (see also results from other runs in the third row of Fig. $4 \mathrm{a}$ and c) is consistent with that inferred from hydrocarbon concentration ratios in the springtime Arctic (Ramacher et al., 1999; Boudries and Bottenheim, 2000). On day 5, soon after the ozone mixing ratio drops below $4 \mathrm{nmol} \mathrm{mol}^{-1}, \mathrm{HBr}$ takes over $\mathrm{BrO}$ as the most abundant bromine species in the gas phase. Also, $\mathrm{HBr}$ is taken up by sulfate aerosols and remains as particulate $\mathrm{Br}^{-}\left(\mathrm{p}-\mathrm{Br}^{-}\right)$without producing $\mathrm{Br}_{2}$. Afterwards, the nighttime buildup of $\mathrm{Br}_{2}$ at $\sim 2-3 \mathrm{pmol} \mathrm{mol}^{-1}$ arises from its release from the snowpack.

The partitioning of gaseous bromine is vastly different in the SIA. $\mathrm{HOBr}, \mathrm{HBr}$ and $\mathrm{BrONO}_{2}$ are produced via gasphase chemistry in the SIA, while they are rapidly taken up by the LLL. Therefore these species never constitute major fractions in the gaseous bromine partitioning in the SIA. Under the conditions specified in our study, $\mathrm{Br}_{2}$ is formed efficiently via the uptake of $\mathrm{HOBr}$ and $\mathrm{BrONO}_{2}$ onto the LLL. Despite the fast photolysis of $\mathrm{Br}_{2}$, its mixing ratio in the SIA increases sharply during the day, reaching as high as $300 \mathrm{pmol} \mathrm{mol}^{-1}$. Along with $\mathrm{BrO}$ formed via Reactions (R2)-(R3) to reach $\sim 100 \mathrm{pmol} \mathrm{mol}^{-1}$ during the day, $\mathrm{Br}_{2}$ predominates the partitioning of gaseous bromine species in the SIA. The steady-state mixing ratios of $\mathrm{Br}_{2}$ at night in the SIA are created by a balance between the oxidation of $\mathrm{Br}^{-}$by $\mathrm{O}_{3}$ in the LLL (Haag and Hoigné, 1983; Oldridge and Abbatt, 2011) and the evasion of $\mathrm{Br}_{2}$ to the atmosphere. Interestingly, even after the maturity of ODEs in the ambient air, $\mathrm{Br}_{2}$ in the SIA builds up to mixing ratios higher than $100 \mathrm{pmol} \mathrm{mol}^{-1}$. This underlines a notable contribution to the $\mathrm{Br}_{2}$ production from aqueous-phase radi- cal chemistry initiated by the formation of $\mathrm{OH}$ via photolysis of $\mathrm{NO}_{3}^{-}$and $\mathrm{H}_{2} \mathrm{O}_{2}$ in the LLL (Abbatt et al., 2010; Thomas et al., 2011). Overall, however, the "bromine explosion", viz., Reactions (R1)-(R4), is a major contributor to the buildup of reactive bromine in the SIA, as indicated from higher insnow mixing ratios of $\mathrm{Br}_{2}$ by more than a factor of two before ozone is depleted at the beginning of the model run.

Here we arrive at an important question: what is the share of $\mathrm{HOBr}$ deposition from the atmosphere in the outflux of $\mathrm{Br}_{2}$ from the snowpack? Vertical fluxes of individual bromine species across the top $1 \mathrm{~mm}$ of the snowpack indicate that $\mathrm{HOBr}$ and $\mathrm{HBr}$ entering from the atmosphere are both taken up almost completely within this very thin layer (Fig. 7a-c). The reactive uptake of $\mathrm{HOBr}$ onto LLL leads to a significant addition to the $\mathrm{Br}_{2}$ outflux within this top $1 \mathrm{~mm}$ layer of the snowpack. However, this results largely from the simultaneous uptake of $\mathrm{HBr}$ entering from the atmosphere. Therefore, the net flux of bromine does not change as much (see black dotted lines in Fig. 7a-c). As shown in Fig. 8a, the net flux of inorganic gaseous bromine accumulates over some distance across the snowpack layers, including this thin top layer but particularly within the top 5 to $10 \mathrm{~cm}$. During the first couple of days, entire layers from the top of the snowpack down to $\sim 25 \mathrm{~cm}$ depth serve as a net source of gaseous bromine, whereas, after ozone is depleted, the top $1 \mathrm{~mm}$ layer of the snowpack serves as a net sink for gaseous bromine most of the time (Fig. 8b). In other words, the "bromine explosion", by which $\mathrm{Br}_{2}$ is released from the snowpack in return for the atmospheric deposition of $\mathrm{HOBr}$ as set out by Lehrer et al. (2004), is a minor contributor to the atmospheric buildup of reactive bromine in this case. Also, the assumption that entire snowpack on sea ice is exposed to $\mathrm{HOBr}$ deposited from the atmosphere (Tang and McConnell, 1996; Michalowski et al., 2000) seems unrealistic even in the presence of ventilation due to wind pumping. Below the topmost layers (whose thickness is $\sim 1 \mathrm{~mm}$ in our model runs), in-snow bromine activation is probably controlled by a chemical environment in the snowpack itself where ozone imported from the atmosphere and aqueousphase radical sources (such as $\mathrm{NO}_{3}^{-}$) play critical roles.

Actually, a swift depletion of $\mathrm{Br}^{-}$in the top $1 \mathrm{~mm}$ of the snowpack explains why the deposition of $\mathrm{HOBr}$ from the atmosphere does not contribute much to the net release of reactive bromine from the snowpack in the model run discussed above. By noon on day 1 , the concentrations of $\mathrm{Br}^{-}$in the top $1 \mathrm{~mm}$ of snowpack drop more than 100 -fold from the initial concentration of $0.108 \mu \mathrm{molL}^{-1}$ (Fig. 4b, bottom panel, and Fig. S8c in the Supplement). Up to that point, the top $1 \mathrm{~mm}$ layer of snowpack has contributed more than $20 \%$ to the net release of bromine to the atmosphere (Fig. 8a). Afterwards, the reactive uptake of $\mathrm{HOBr}$ on this layer of snowpack forms $\mathrm{Cl}_{2}$, instead of $\mathrm{Br}_{2}$, via Reactions (R5), (R12) and (R13):

$\mathrm{BrCl}_{\mathrm{aq}}+\mathrm{Cl}_{\mathrm{aq}}^{-} \rightleftarrows \mathrm{BrCl}_{2 \mathrm{aq}}^{-}$
$\mathrm{BrCl}_{2 \mathrm{aq}}^{-} \rightleftarrows \mathrm{Cl}_{2 \mathrm{aq}}+\mathrm{Br}_{\mathrm{aq}}^{-}$ 

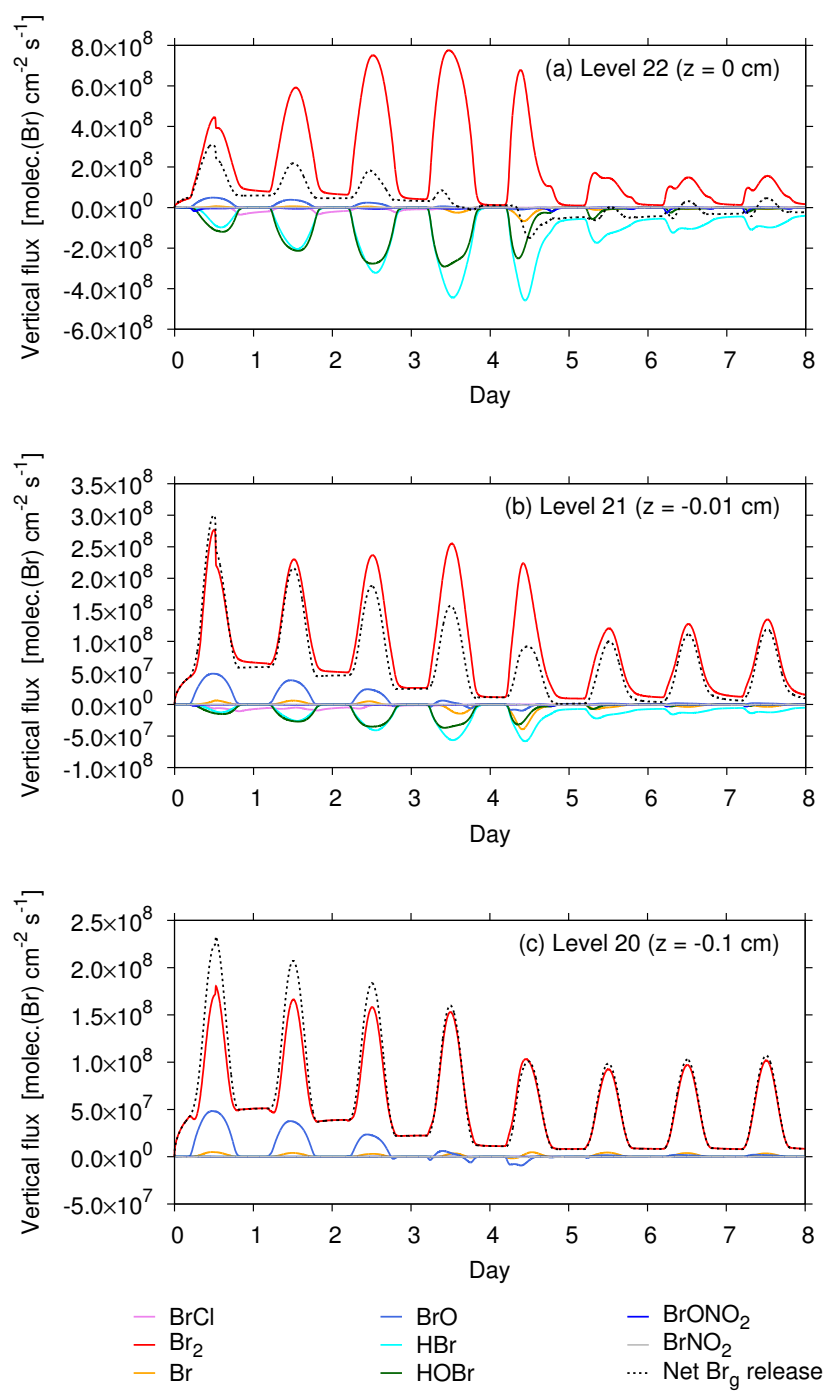

Fig. 7. Vertical fluxes of major inorganic bromine species in the top $1 \mathrm{~mm}$ of the snowpack as simulated at $U_{2}=4.5 \mathrm{~ms}^{-1}$ and $N=0.031 \mathrm{~s}^{-1}$ : (a) $z=0 \mathrm{~cm}$ (the top of the snowpack), (b) $z=$ $-0.01 \mathrm{~cm}$, and (c) $z=-0.1 \mathrm{~cm}$.

followed by the release of $\mathrm{Cl}_{2}$ to the gas phase. We note, however, that this mechanism accounts for only a minor portion of gaseous chlorine fluxes in our model. $\mathrm{HCl}$ evasion from the top $1 \mathrm{~mm}$ of snowpack (to be discussed in Sect. 3.3) always dominates over the second most important contribution from $\mathrm{Cl}_{2}$ evasion (Fig. S8a in the Supplement). A major source of reactive chlorine species in our model atmosphere is provided by the reactive uptake of $\mathrm{HOBr}$ and $\mathrm{HCl}$ on sulfate aerosols to give $\mathrm{BrCl}$ (Fig. S9a in the Supplement). Also, the atmospheric mixing ratios of $\mathrm{Cl}_{2}$ simulated in our model are no more than 2 pmol mol $^{-1}$ (Fig. S9a in the Supplement) and thus cannot explain a strong source suggested from very high mixing ratios (up to $400 \mathrm{pmol} \mathrm{mol}^{-1}$ ) measured in surface air at Barrow in the spring of 2009 (Liao et al., 2014). Once ozone is depleted significantly, the de-
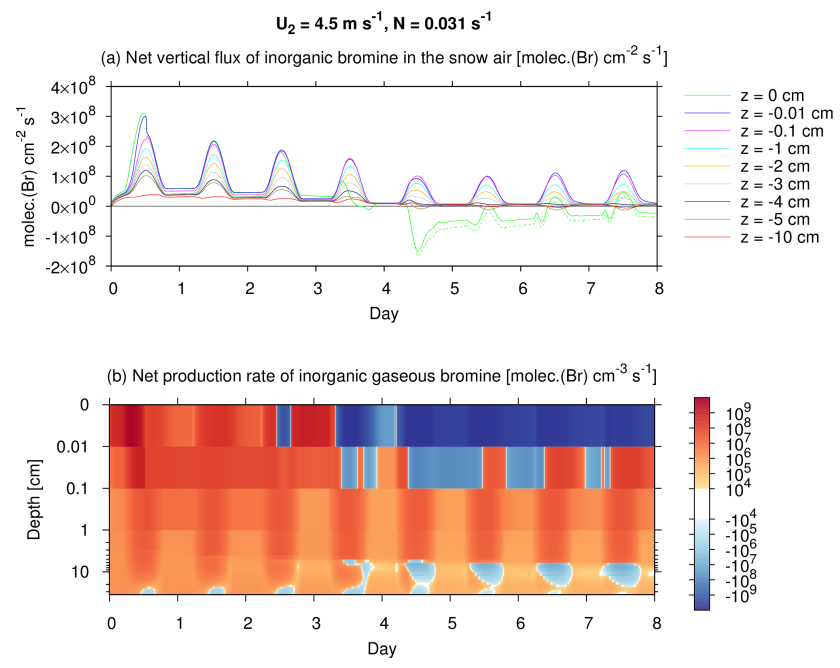

Fig. 8. Budget analyses of inorganic gaseous bromine in the snowpack as simulated in the model run with $U_{2}=4.5 \mathrm{~m} \mathrm{~s}^{-1}$ and $N=$ $0.031 \mathrm{~s}^{-1}$ : (a) vertical fluxes at selected depth levels (solid lines) and the sum of the vertical fluxes of inorganic gaseous bromine and aerosol bromide at the top of the snowpack (green dotted line), and (b) net production (mostly via condensed-phase chemistry on the snow grain surface and subsequent release of products to the interstitial air).

position of gaseous $\mathrm{HBr}$ and aerosol $\mathrm{Br}^{-}$returns bromine, which has been released mainly from deeper layers of the snowpack, back to the top $1 \mathrm{~mm}$ of snowpack where the $\mathrm{Br}^{-}$concentrations reach $\sim 1 \mu \mathrm{molL}^{-1}$ by the end of each 8-day model run at $U_{2}=2-8.5 \mathrm{~m} \mathrm{~s}^{-1}$ (Fig. $4 \mathrm{a}-\mathrm{c}$, bottom panels). Such a great range of variations in the concentration of $\mathrm{Br}^{-}$(relative to those of $\mathrm{Cl}^{-}$and $\mathrm{Na}^{+}$) has been noted previously in the field measurements of polar snowpack chemistry (Ariya et al., 1999; Simpson et al., 2005; Jacobi et al., 2012; Krnavek et al., 2012).

Hence, in the real environment, the release of gaseous bromine from the snowpack may often recur after the redistribution of snowpack $\mathrm{Br}^{-}$during previous ODEs. To investigate what might happen in this situation, we have conducted sensitivity runs in which the initial concentration of $\mathrm{Br}^{-}$is raised by a factor of 10 to $1.08 \mu \mathrm{molL}^{-1}$ in the top $1 \mathrm{~mm}$ of snowpack. Unlike model runs starting from the same molar ratio between $\mathrm{Br}^{-}$and $\mathrm{Cl}^{-}$as in seawater throughout the snowpack, the $\mathrm{Br}^{-} / \mathrm{Cl}^{-}$molar ratio is simulated to remain higher than the seawater ratio in the top $1 \mathrm{~mm}$ of snowpack (Fig. S8c in the Supplement). As shown in Fig. 9a-b, the production of gaseous bromine resulting from the atmospheric deposition of $\mathrm{HOBr}$ remains substantial for the first couple of days and accounts for up to $\sim 40 \%$ of the net vertical flux of bromine out of the snowpack in this case at $U_{2}=4.5 \mathrm{~m} \mathrm{~s}^{-1}$. For model runs at $U_{2}=4.5 \mathrm{~m} \mathrm{~s}^{-1}$ and $8.5 \mathrm{~m} \mathrm{~s}^{-1}$, the buildup of reactive bromine and the resultant depletion of ozone in the $\mathrm{ABL}$ accelerate notably by using this adapted scenario 

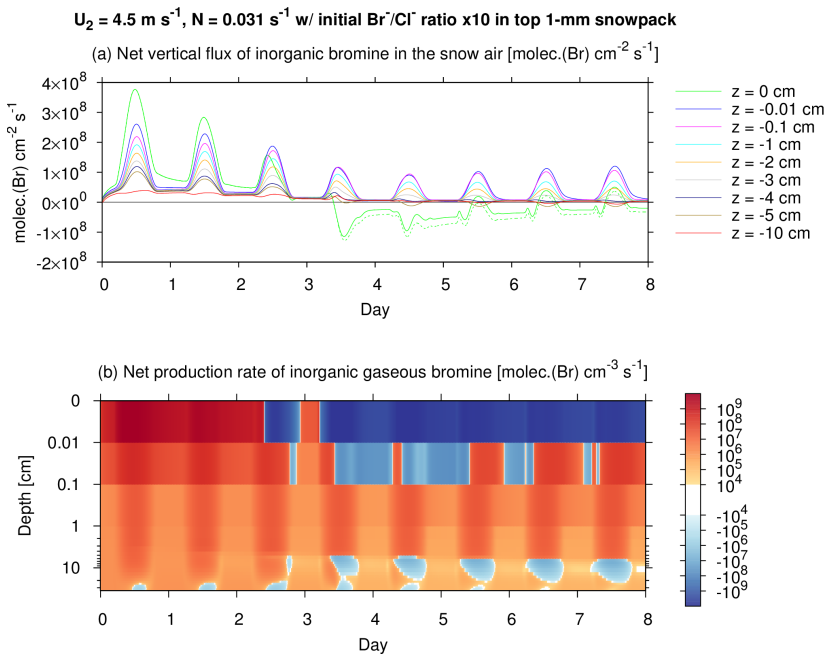

Fig. 9. The same as Fig. 8 but from a model run in which the initial concentration of $\mathrm{Br}^{-}$is increased by a factor of 10 in the top $1 \mathrm{~mm}$ of the snowpack.

with a 10-fold increase in the initial concentration of $\mathrm{Br}^{-}$in the top $1 \mathrm{~mm}$ of snowpack (Fig. 10).

The amount of in-snow measurements conducted to date in the field is not abundant enough to evaluate confidently how realistic our simulations are in terms of reactive bromine levels in the SIA. First of all, measuring the mixing ratios of reactive gases in the SIA poses a challenge, because the pumping of air for the sampling purpose can be a significant source of artifact by drawing ambient air down into the SIA (Albert et al., 2002). The only in-snow measurements that we know for gaseous reactive bromine are those performed by Foster et al. (2001) at Alert $\left(82^{\circ} \mathrm{N}\right)$ in early March. Gaseous $\mathrm{Br}_{2}$ mixing ratios in the top $5 \mathrm{~cm}$ of the snowpack were found to be enhanced to $\sim 2 \mathrm{pmol} \mathrm{mol}^{-1}$ as compared to $\sim 1 \mathrm{pmol} \mathrm{mol}^{-1}$ in the ambient air, which does not necessarily support our results with up to $\sim 300 \mathrm{pmol} \mathrm{mol}^{-1}$ of $\mathrm{Br}_{2}$ simulated in the SIA. On the other hand, from insitu measurements in SIA at Summit, Greenland, during the summer, Peterson and Honrath (2001) found diurnal variations in ozone mixing ratio similar to our simulations. From the amplitude of daytime ozone decrease, these authors deduced higher than $160 \mathrm{pmol} \mathrm{mol}^{-1}$ of $\mathrm{BrO}$ to exist in the SIA. However, such a high mixing ratio of $\mathrm{BrO}$ was not simulated by Thomas et al. (2011), who obtained only about $15 \mathrm{pmol} \mathrm{mol}^{-1}$ of $\mathrm{BrO}$ in the SIA, with a 1-D model similar to ours but configured for the study of reactive bromine and nitrogen chemistry in the snowpack and its impacts on chemistry in the overlying ambient air at Summit. Neither did their simulation obtain daytime ozone decline in the SIA as large as the observation by Peterson and Honrath (2001). While we have not been successful in carrying out model runs to address this issue (see Sect. S4 in the Supplement), we speculate that the difference in halide concentrations in the LLL

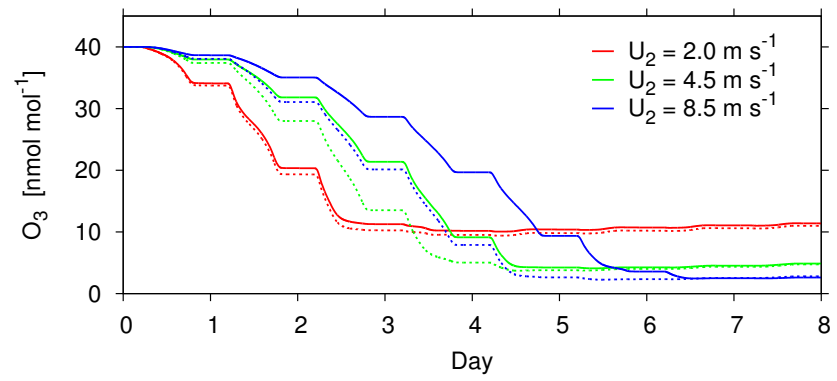

Fig. 10. Simulated sensitivity of the timescale of ozone depletion in the air (at the height of $1.5 \mathrm{~m}$ ) at $U_{2}=2.0 \mathrm{~m} \mathrm{~s}^{-1}$ (red lines), $4.5 \mathrm{~m} \mathrm{~s}^{-1}$ (green lines) and $8.5 \mathrm{~m} \mathrm{~s}^{-1}$ (blue lines) on the initial concentration of $\mathrm{Br}^{-}$in the top $1 \mathrm{~mm}$ of snowpack. Solid lines denote results from our baseline scenario with initial $\mathrm{Br}^{-} / \mathrm{Cl}^{-}$molar ratio at $1 / 650$ in the entire snowpack, whereas dotted lines denote results from sensitivity runs in which initial $\mathrm{Br}^{-}$concentration in the snowpack is raised by a factor of 10 between $0-1 \mathrm{~mm}$ in depth (i.e., top two layers in the model snowpack).

between our model and the Thomas et al. (2011) model can at least partly explain quite different levels of in-snow bromine activation simulated by the two models. Recurring, large daytime declines in the in-snow ozone mixing ratios similar to Peterson and Honrath (2001) were observed later again at Summit (Helmig et al., 2007a). At Arctic coastal sites, Alert and Barrow, ozone has been found to be depleted (by more than $10 \mathrm{nmol} \mathrm{mol}^{-1}$ ) persistently in SIA relative to overlying ambient air, but with no apparent diurnal variations in the mixing ratios unlike our simulations (Albert et al., 2002; Helmig et al., 2012). For the in-snow ozone data by Albert et al. (2002), the lack of diurnal variations may however be attributable to the $24 \mathrm{~h}$ exposure to sunlight in April at Alert.

\subsection{The role of acidity for bromine activation in snowpack}

By adopting snowpack salinity lower than that often found on first-year sea ice and refrozen leads (cf. Krnavek et al., 2012) in our model runs, we could assume that alkalinity of seawater origin had been titrated sufficiently by acidity carried in with nitrate at a level typically found in Arctic snowpack (Sect. 2.10). Hence our model runs start with the initial $\mathrm{pH}$ of 4 in the LLL on snow grains. Figure 11a-c show the evolution of major ionic composition and $\mathrm{pH}$ in the LLL and gaseous $\mathrm{HCl}$ as simulated in model runs at $U_{2}=2.0 \mathrm{~m} \mathrm{~s}^{-1}$, $4.5 \mathrm{~m} \mathrm{~s}^{-1}$, and $8.5 \mathrm{~ms}^{-1}$, respectively. Values of $\mathrm{pH}$ in the LLL evolve during the course of model runs in response to further deposition of nitrate gases and sulfate aerosols from the atmosphere; the $\mathrm{pH}$ in the LLL remains in the range of $3-5$ below the depth of $4-9 \mathrm{~cm}$ (depending on model runs) in the snowpack while being lowered further towards $\sim 2$ in the top snowpack layers primarily via dry deposition of sulfate aerosols. We note that our model neglects the precipitation of mirabilite $\left(\mathrm{Na}_{2} \mathrm{SO}_{4} \cdot 10 \mathrm{H}_{2} \mathrm{O}\right)$, which most likely takes 
(a) $\mathrm{U}_{2}=2 \mathrm{~m} \mathrm{~s}^{-1}$
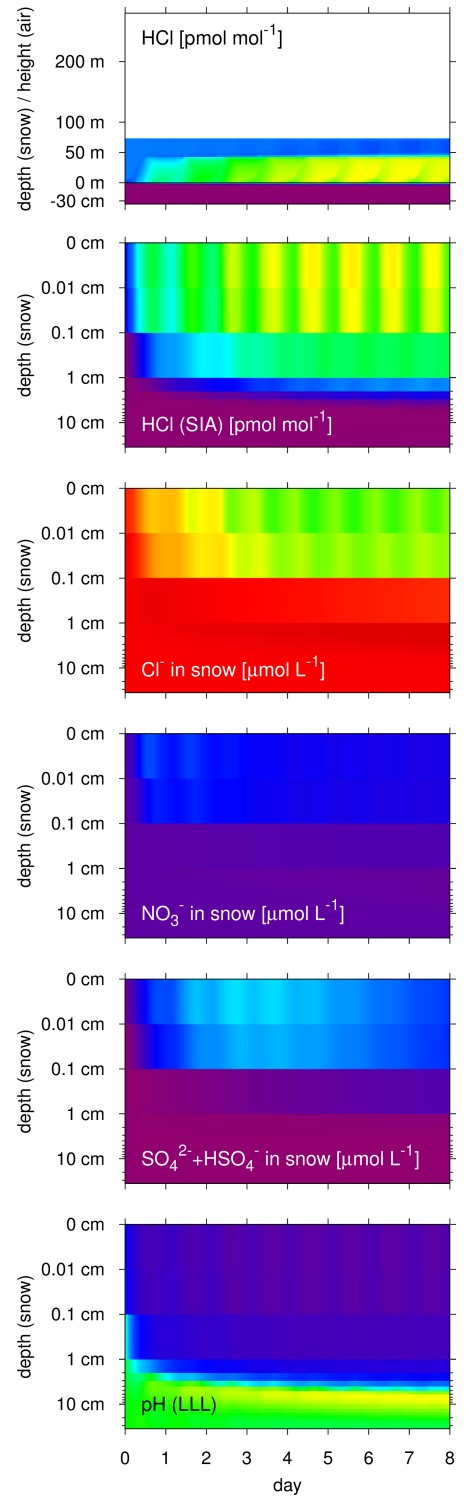

(b) $\mathrm{U}_{2}=4.5 \mathrm{~m} \mathrm{~s}^{-1}$
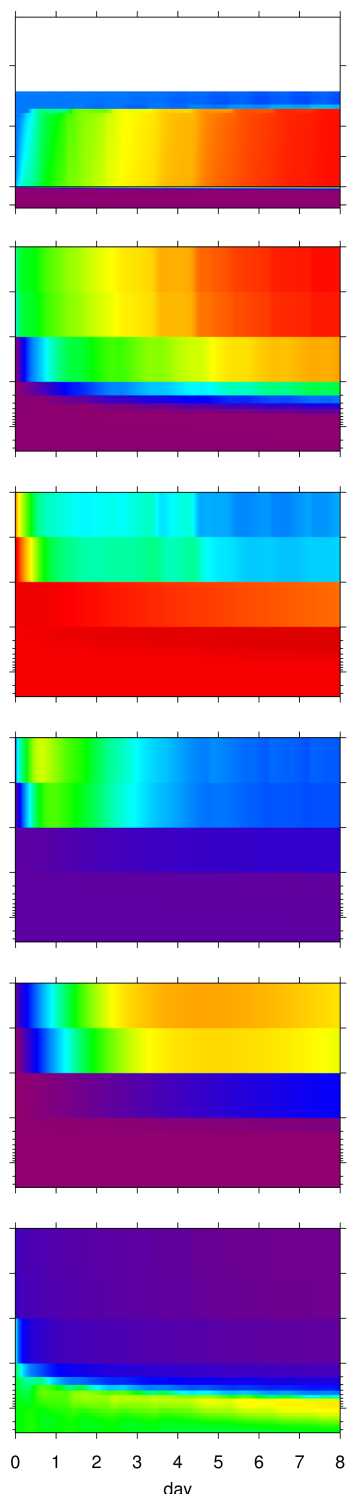

(c) $\mathrm{U}_{2}=8.5 \mathrm{~m} \mathrm{~s}^{-1}$
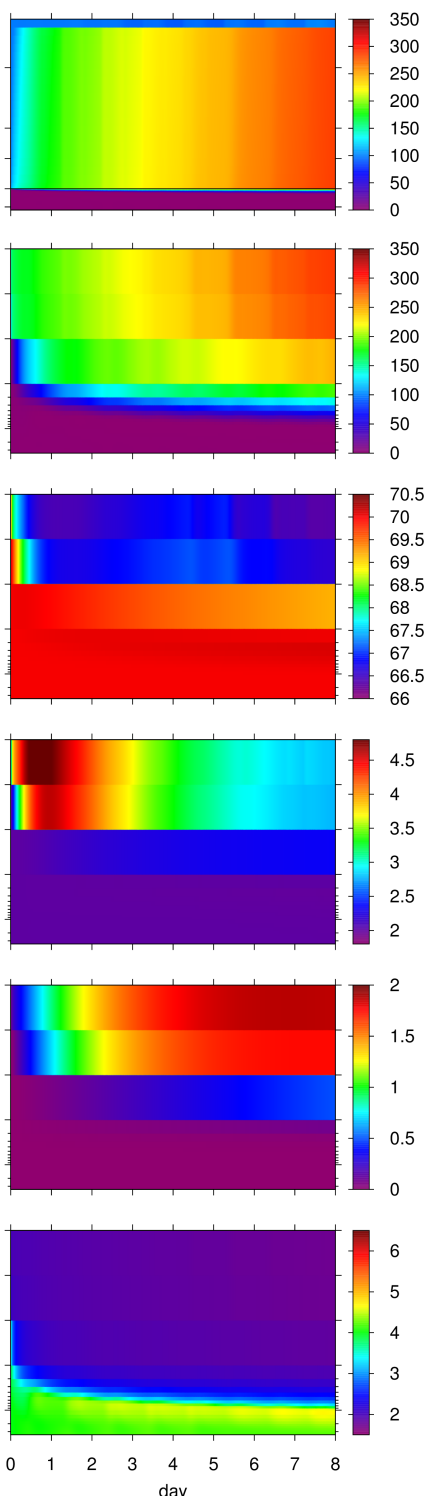

Fig. 11. Time-height cross sections for the mixing ratios of $\mathrm{HCl}$ (top row for the entire model domain from the bottom of the SIA and to the top of the atmosphere and second row for the SIA only), bulk concentrations of chloride $\left(\mathrm{Cl}^{-}\right.$, third row), nitrate ( $\mathrm{NO}_{3}^{-}$, fourth row) and sulfate $\left(\mathrm{SO}_{4}^{2-}+\mathrm{HSO}_{4}^{-}\right.$, fifth row) in snowpack grains, and $\mathrm{pH}$ in the LLL on the surface of snowpack grains (bottom row) from model runs with $U_{2}=2.0 \mathrm{~m} \mathrm{~s}^{-1}$ (a), $4.5 \mathrm{~m} \mathrm{~s}^{-1}$ (b), and $8.5 \mathrm{~m} \mathrm{~s}^{-1}$ (c).

place when sulfate aerosols enter the LLL with sufficiently high sodium content at the temperature of $253 \mathrm{~K}$ as assumed here (e.g., Weeks and Hibler III, 2010, see Chap. 6). However, this should not pose a major problem for our prediction of the LLL acidity, because the formation of mirabilite will simply leave behind $\mathrm{H}^{+}$that has entered the snowpack LLL via dry deposition of $\mathrm{HSO}_{4}^{-}$and $\mathrm{H}_{2} \mathrm{SO}_{4}$ in the aerosols (see Sect. S6 in the Supplement). In our model framework, the multiphase transfer of $\mathrm{HCl}$ between SIA and LLL also plays a critical role in buffering the $\mathrm{pH}$ in the LLL. The buffer ef- fect operates in that acidity input to the LLL via dry deposition of acidic nitrate gases and sulfate aerosols induces the release of $\mathrm{HCl}$ from the LLL to the SIA and then the evasion of $\mathrm{HCl}$ to the ABL. The same type of mechanism that involves $\mathrm{HCl}$ is known to buffer the level of $\mathrm{pH}$ in deliquesced sea-salt aerosols across super- $\mu \mathrm{m}$ size fractions in the marine boundary layer (Keene et al., 2002).

We use this dependence of simulated $\mathrm{pH}$ in the LLL on gaseous $\mathrm{HCl}$ levels as a tool for studying the sensitivity of snowpack bromine activation to $\mathrm{pH}$ in the LLL. By fixing 
(a) $\mathrm{HCl}(\mathrm{SIA})=100 \mathrm{pmol} \mathrm{mol}^{-1}$

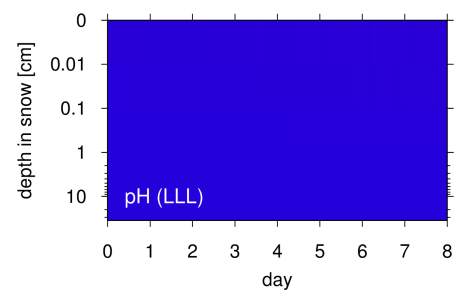

(b) $\mathrm{HCl}(\mathrm{SIA})=1 \mathrm{pmol} \mathrm{mol}^{-1}$

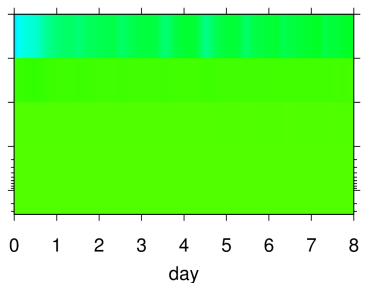

(c) $\mathrm{HCl}(\mathrm{SIA})=10^{-2} \mathrm{pmol} \mathrm{mol}^{-1}$

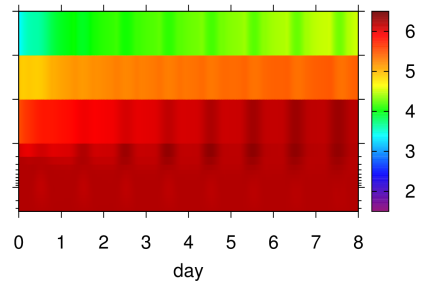

Fig. 12. Time-height cross sections for simulated $\mathrm{pH}$ in the LLL on the surface of snowpack grains from model runs in which gas-phase $\mathrm{HCl}$ mixing ratio in the SIA is fixed deliberately at $100 \mathrm{pmol} \mathrm{mol}^{-1}$ (a), $1 \mathrm{pmol} \mathrm{mol}^{-1}$ (b), and $0.01 \mathrm{pmol} \mathrm{mol}^{-1}$ (c), while in the ambient air it is fixed at $100 \mathrm{pmol} \mathrm{mol}^{-1}$ for all the cases.

the mixing ratio of $\mathrm{HCl}$ to an arbitrary value in the SIA and, in other model runs, increasing or decreasing this value by a factor of 100 , we deliberately change the LLL acidity by a factor of $\sim 4$ in $\mathrm{pH}$ scale between the model runs (Fig. 12a-c). In the first sensitivity run, we fix the mixing ratio of $\mathrm{HCl}$ at $1 \mathrm{pmol} \mathrm{mol}^{-1}$ in the SIA. In this case, the model maintains the pH level close to 4 in the LLL of the entire snowpack. The simulated rates of reactive bromine release from the snowpack and of resultant ozone loss in the ABL (Fig. S12b in the Supplement) do not change very much from those simulated in the model run discussed in preceding subsections (Fig. 4b) without deliberate $\mathrm{HCl}$ adjustment where $\mathrm{pH}$ stays $3-5$ below the depth of $4 \mathrm{~cm}$ and goes down to $\sim 2$ in the top $1 \mathrm{~mm}$ of snowpack (Fig. 11b). In other two cases where much lower $(\sim 2)$ and higher $(\sim 6) \mathrm{pH}$ levels are deliberately produced in the LLL, the model simulates much stronger and weaker levels of in-snow bromine activation, respectively (Fig. S12a and c in the Supplement). Net vertical fluxes of gaseous bromine out of the snowpack change by an order of magnitude between these three model runs (Fig. 13). If the $\mathrm{HCl}$ level is fixed in the SIA at $0.01 \mathrm{pmol} \mathrm{mol}^{-1}$, the $\mathrm{pH}$ in the LLL approaches $\sim 6.5$ below the $1 \mathrm{~mm}$ depth of the snowpack (Fig. 12c), rendering these layers of the snowpack a net sink for gaseous bromine during both daytime and nighttime after day 5 , even though ozone mixing ratios remain relatively high at $\sim 20-30 \mathrm{pmol} \mathrm{mol}^{-1}$ (Fig. $14 \mathrm{c}$ and Fig. S12c in the Supplement). This is in marked contrast to results from model runs with lower $\mathrm{pH}$ values in the LLL where the net production rate of gaseous bromine stays positive below the $1 \mathrm{~mm}$ depth of the snowpack even after the depletion of ozone (Fig. 14a-b and Fig. S12a-c in the Supplement).

In order to address the issue of how the levels of the $\mathrm{pH}$ evolve in the LLL of the snowpack, we should employ a more sophisticated approach than currently adopted in PHANTAS, perhaps by properly formulating processes such as the nonideal solution behavior of brine, the precipitation of salts from freezing brine, and the partitioning of solutes in the solid ice matrix (e.g., Marion and Farren, 1999; Kuo et al., 2011). This will be a subject of further studies using PHANTAS.

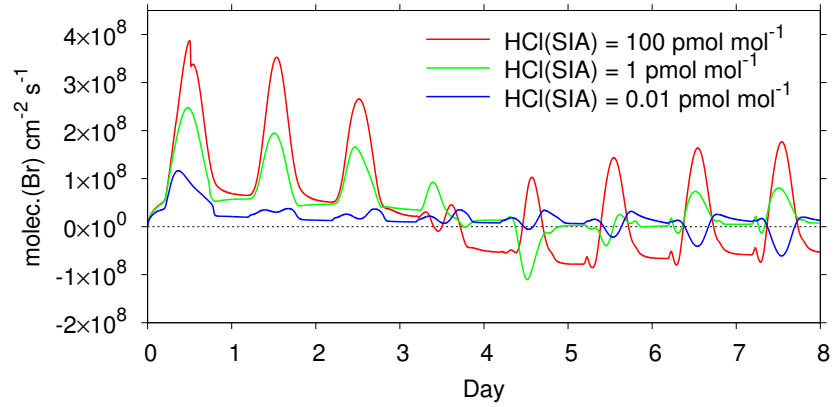

Fig. 13. Net vertical fluxes of inorganic bromine gases at the interface between the snowpack and the atmosphere as simulated in the same model runs presented in Fig. 12a-c, i.e., using the fixed mixing ratios of $\mathrm{HCl}$ in the SIA at $100 \mathrm{pmol} \mathrm{mol}^{-1}$ (red line), $1 \mathrm{pmol} \mathrm{mol}^{-1}$ (green line), and $0.01 \mathrm{pmol} \mathrm{mol}^{-1}$ (blue line), while in the ambient air they are fixed at $100 \mathrm{pmol} \mathrm{mol}^{-1}$ for all the cases.

\subsection{Air-snow fluxes of ozone}

Ozone is known to undergo dry deposition to various surfaces, including the snow surface (Helmig et al., 2007b). In essence, dry deposition velocity $\left(v_{\mathrm{d}}\right)$ at an arbitrary height can be expressed by the inverse of the sum of aerodynamic resistance $\left(r_{\mathrm{a}}\right)$, quasi-laminar layer resistance $\left(r_{\mathrm{b}}\right)$ and surface resistance $\left(r_{\mathrm{s}}\right)$ :

$v_{\mathrm{d}}=\left(r_{\mathrm{a}}+r_{\mathrm{b}}+r_{\mathrm{s}}\right)^{-1}$,

where $r_{\mathrm{a}}$ and $r_{\mathrm{b}}$ are determined by turbulent and molecular diffusivity in the atmosphere and $r_{\mathrm{s}}$ by solubility and reactivity of a depositing gas in/on the substrate (Wesely, 1989). The vertical fluxes of gases $\left(F_{\mathrm{g}}\right)$ at the height where $v_{\mathrm{d}}$ is determined can then be related to their concentrations $\left(\chi_{\mathrm{g}}\right)$ :

$F_{\mathrm{g}}=-v_{\mathrm{d}} \cdot \chi_{\mathrm{g}}$.

By combining the two equations above, we obtain

$r_{\mathrm{s}}=-\left(\chi_{\mathrm{g}} / F_{\mathrm{g}}+r_{\mathrm{a}}+r_{\mathrm{b}}\right)$,

where $\chi_{\mathrm{g}}, F_{\mathrm{g}}$ and $r_{\mathrm{a}}+r_{\mathrm{b}}$ are all known quantities in our model. Since this model is elaborated in the parameterization 

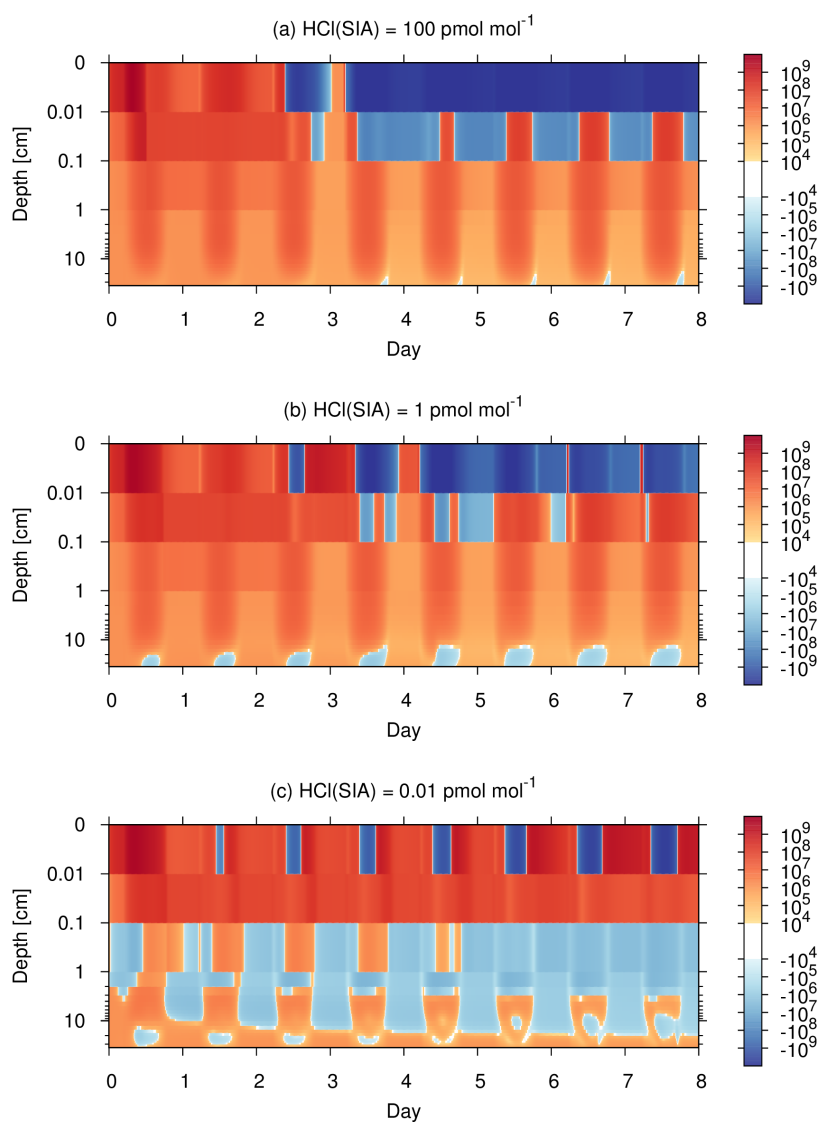

Fig. 14. Time-height cross sections for the simulated net production rates of inorganic bromine gases in the SIA (unit: molecule $(\mathrm{Br}) \mathrm{cm}^{-3} \mathrm{~s}^{-1}$ ) from the same model runs presented in Fig. $12 \mathrm{a}-\mathrm{c}$, i.e., using the fixed mixing ratios of $\mathrm{HCl}$ in the SIA at $100 \mathrm{pmol} \mathrm{mol}^{-1}$ (a), $1 \mathrm{pmol} \mathrm{mol}^{-1}$ (b), and $0.01 \mathrm{pmol} \mathrm{mol}^{-1}$ (c), while in the ambient air it is fixed at $100 \mathrm{pmol} \mathrm{mol}^{-1}$ for all the cases.

of $r_{\mathrm{a}}$ and $r_{\mathrm{b}}$ (see Sect. 2.7) as well as in-snow chemical processes that are linked to $r_{\mathrm{s}}$, a comparison between the $r_{\mathrm{s}}$ values derived from the simulation by using Eq. (25) and from ozone flux measurements in the field gives useful insights into whether or not the in-snow ozone loss simulated in our model is realistic.

Top panels in Fig. 15a-c show apparent dry deposition velocities $\left(v_{\mathrm{d}}^{*}=-\chi_{\mathrm{g}} / F_{\mathrm{g}}\right)$ for ozone at four different height levels in ambient air above the snow surface as simulated at $U_{2}=2.0 \mathrm{~m} \mathrm{~s}^{-1}, 4.5 \mathrm{~m} \mathrm{~s}^{-1}$ and $8.5 \mathrm{~m} \mathrm{~s}^{-1}$, respectively. At the lowest height level $(z=0.5 \mathrm{~cm})$, the $v_{\mathrm{d}}^{*}$ values reach $\sim 10^{-3} \mathrm{~cm} \mathrm{~s}^{-1}$ during daytime as a result of catalytic ozone loss via bromine radical chemistry, which is more active in the SIA than in the ambient air as discussed already. By simply taking an inverse of $v_{\mathrm{d}}^{*}$, the minimum value of $r_{\mathrm{s}}$ for ozone on the snow surface in our model is inferred to be on the order of $10^{5} \mathrm{~s} \mathrm{~m}^{-1}$, as the values of $r_{\mathrm{a}}$ and $r_{\mathrm{b}}$ at $z=0.5 \mathrm{~cm}$ are much smaller. Interestingly, $v_{\mathrm{d}}^{*}$ can be more than doubled within the lowest several meters of the atmosphere, because bromine chemistry across this layer augments the downward flux of ozone from above as much as the in-snow bromine chemistry sets it out at the bottom of the atmosphere. After the maturity of ODEs, negative dry deposition velocities for ozone become evident for model runs at $U_{2}=4.5 \mathrm{~m} \mathrm{~s}^{-1}$ and $8.5 \mathrm{~m} \mathrm{~s}^{-1}$. This reflects the evasion of ozone out of the SIA to the atmosphere, as the net photochemical production of ozone involving $\mathrm{NO}_{\mathrm{x}}$ leads to higher concentrations of ozone in the SIA. However, as can be seen in Fig. 5e from changes in ozone mixing ratios in ambient air, this in-snow source of ozone after the maturity of ODEs does not contribute much to the recovery of ozone levels in the ABL at $U_{2}=4.5 \mathrm{~m} \mathrm{~s}^{-1}$ and $8.5 \mathrm{~m} \mathrm{~s}^{-1}$.

The reported range of the $v_{\mathrm{d}}^{*}$ values for ozone over the polar snow surface is much broader than derived here from our model runs. Recently, by using ozone flux measurements at a meteorological tower, the $v_{\mathrm{d}}^{*}$ values were derived to be on the order of $0.01 \mathrm{~cm} \mathrm{~s}^{-1}$ (hence on the order of $10^{4} \mathrm{~s} \mathrm{~m}^{-1}$ in terms of $r_{\mathrm{s}}$ ) over the snow surface at Barrow during the spring (Helmig et al., 2012). From a comparison of surface ozone mixing ratios simulated by a 3-D chemical transport model with observations across polar regions, Helmig et al. (2007a) concluded that the typical $v_{\mathrm{d}}^{*}$ value for ozone on the polar snow should also be on the order of $0.01 \mathrm{~cm} \mathrm{~s}^{-1}$ during the winter. Over sea ice in Hudson Bay during early spring, the values of $v_{\mathrm{d}}^{*}$ derived from ozone flux measurements varied between -1.5 and $+0.5 \mathrm{~mm} \mathrm{~s}^{-1}$ (Muller et al., 2012), encompassing more than an order of magnitude greater range than our simulated values. It thus seems that a sink (and a source occasionally) of ozone in the polar snow in nature is much stronger than simulated by our model, unless those field measurements of ozone fluxes were subject to significant artifacts.

Finally, we have plotted the $v_{\mathrm{d}}^{*}$ values for $\mathrm{HOBr}$ and $\mathrm{HBr}$ in the middle and bottom panels of Fig. 15a-c. As expected for compounds highly reactive on the ice surface, we obtain high values of $v_{\mathrm{d}}^{*}$ around $1 \mathrm{~cm} \mathrm{~s}^{-1}$ and thus $r_{\mathrm{s}}$ on the order of $10^{2} \mathrm{~s} \mathrm{~m}^{-1}$. In this case, increases in $v_{\mathrm{d}}^{*}$ with height and with wind speed are both controlled essentially by changes in $r_{\mathrm{a}}$. As noted in Sect. 3.1, this effect poses one of the important factors for modulating the buildup rate of reactive bromine in the ABL. We also stress that we had to adopt a numerical procedure of linearly coupled iteration between the chemistry and transport solvers in order to simulate the $v_{\mathrm{d}}^{*}$ values correctly for these species (see Sect. 2.9).

\subsection{BrO column amounts in the $\mathrm{ABL}$}

As mentioned in the introduction, satellite measurements of $\mathrm{BrO}$ column amounts provide strong evidence for the prevalence of high $\mathrm{BrO}$ levels in the springtime polar boundary layer. On the other hand, while analyzing air mass origins for prolonged ODEs observed during shipboard surface ozone measurements in the middle of Arctic sea ice, 


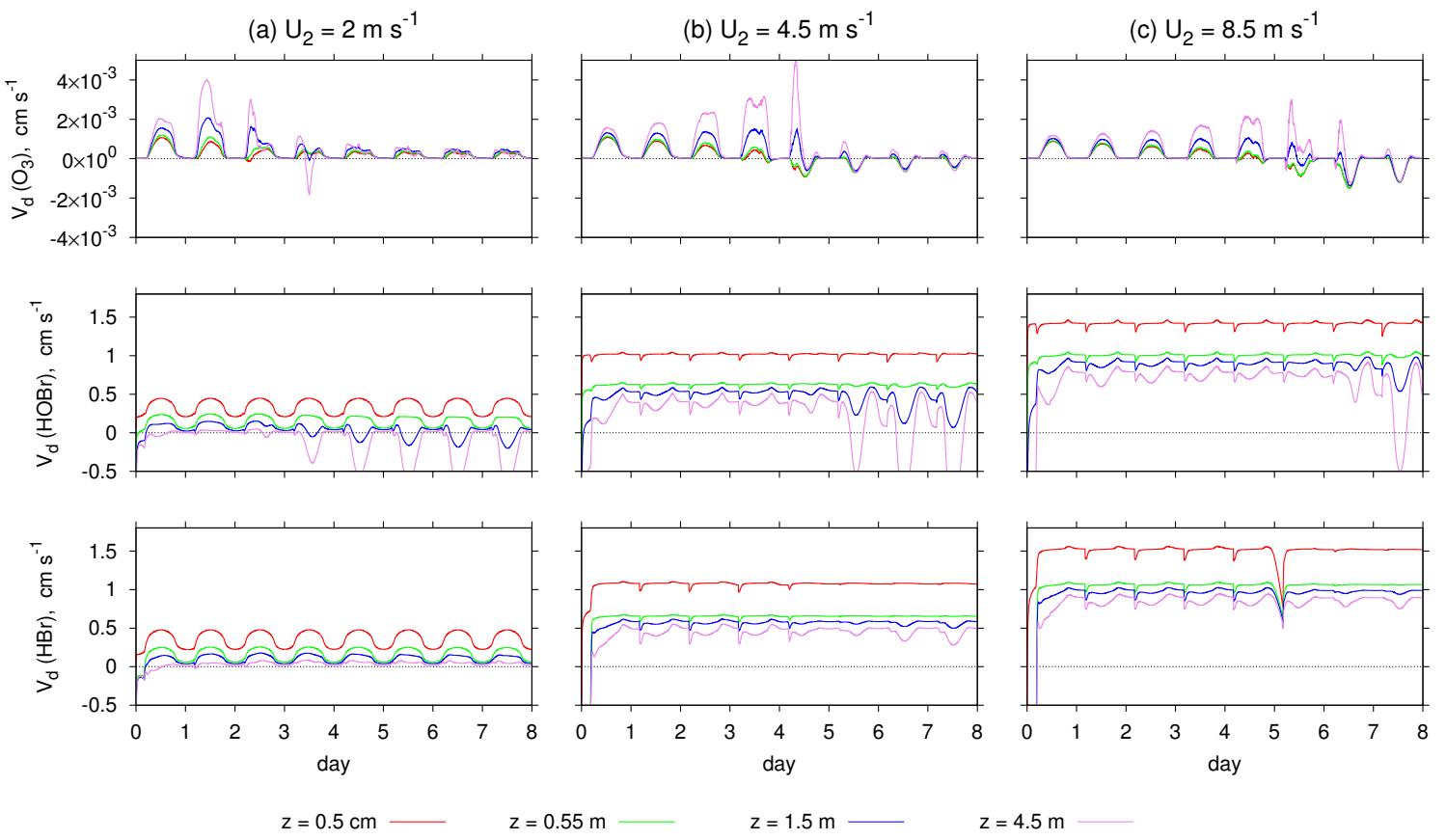

Fig. 15. Apparent dry deposition velocities (at $0.5 \mathrm{~cm}, 55 \mathrm{~cm}, 1.5 \mathrm{~m}$, and $4.5 \mathrm{~m}$ above the snow surface) of $\mathrm{O}_{3}$ (top row), $\mathrm{HOBr}$ (middle row) and $\mathrm{HBr}$ (bottom row) from model runs with $U_{2}=2.0 \mathrm{~m} \mathrm{~s}^{-1}$ (a), $4.5 \mathrm{~m} \mathrm{~s}^{-1}$ (b) and $8.5 \mathrm{~m} \mathrm{~s}^{-1}$ (c).

Bottenheim et al. (2009) found that satellite BrO column data were not of much help to make a clear attribution of locations where the air masses may have undergone active ozone loss via bromine chemistry. A similar problem was noted from Antarctic ODEs associated with low inversion height $(<100 \mathrm{~m})$ over sea ice common to low wind speed conditions (Jones et al., 2010).

The present simulations reconfirm the assertion by Jones et al. (2010). Figure 16a-d show the simulated $\mathrm{BrO}$ columns in the atmosphere at $U_{2}=2,4.5,8.5$ and $12 \mathrm{~ms}^{-1}$, respectively. Contributions from in-snow $\mathrm{BrO}$ columns are negligible as compared to the total column amounts in the atmosphere. Here we also include model runs with higher and lower stability (or $N$ ) assumed in the free atmosphere to investigate the problem for a broader range of the ABL depth $\left(Z_{\mathrm{ABL}}\right.$, see Fig. $\left.2 \mathrm{a}\right)$. At $U_{2}=2.0 \mathrm{~m} \mathrm{~s}^{-1}$ $\left(Z_{\mathrm{ABL}}<58 \mathrm{~m}\right)$, the simulated $\mathrm{BrO}$ column amounts do not exceed $1 \times 10^{13}$ molecule $\mathrm{cm}^{-2} \mathrm{~s}^{-1}$, which would hardly be discerned from variability in $\mathrm{BrO}$ columns above the $\mathrm{ABL}$ and error bars in satellite data retrieval itself. At $U_{2}=4.5 \mathrm{~m} \mathrm{~s}^{-1}\left(Z_{\mathrm{ABL}}=100-175 \mathrm{~m}\right)$, simulated $\mathrm{BrO}$ columns reach $1.5-2 \times 10^{13}$ molecule $\mathrm{cm}^{-2} \mathrm{~s}^{-1}$, which are detectable from satellite probably with fair confidence (e.g., Theys et al., 2011). The maximum column amounts of BrO (3-5 $\times 10^{13}$ molecule $\mathrm{cm}^{-2} \mathrm{~s}^{-1}$ ) simulated at $U_{2}=8.5 \mathrm{~m} \mathrm{~s}^{-1}$ and $12 \mathrm{~m} \mathrm{~s}^{-1}\left(Z_{\mathrm{ABL}}=219-368 \mathrm{~m}\right.$ and $352-588 \mathrm{~m}$, respectively) imply that "BrO clouds" associated with such windy events will likely be identified unambiguously from satellite unless covered under optically thick clouds.
Hence, the "BrO clouds" with particularly high $\mathrm{BrO}$ column densities, as can be seen from satellites, are not necessarily a good indicator to locate the origins of ODEs (and AMDEs), since they are observed at the ground level more often under calm weather than under stormy/gusty weather. Whether or not they lead to prominent ODEs and AMDEs, such "BrO clouds" would indicate bromine activation in the deeper ABL associated with strong surface winds and/or in air masses elevated by low-pressure systems (Jones et al., 2010; Choi et al., 2012), if not concealed by phenomena above the $\mathrm{ABL}$ such as increased $\mathrm{BrO}$ columns near the tropopause driven by atmospheric dynamics in the UTLS (Salawitch et al., 2010).

\section{Conclusions}

For a better understanding of what drives the release of reactive bromine from the snowpack on sea ice, we have developed a 1-D model that describes multiphase chemistry and transport of trace constituents from the porous snowpack through the ABL as a unified system. A common set of multiphase, viz., gaseous and aqueous, chemical mechanisms is employed in the atmosphere containing "haze" aerosols and in the snowpack hosting SIA between snow gains coated by the LLL. The formulation of vertical diffusivity and the configuration of vertical layer spacings are designed such that the model can realistically capture chemical interactions taking place between vastly different chemical environments across the interface of snowpack and overlying ambient air. 

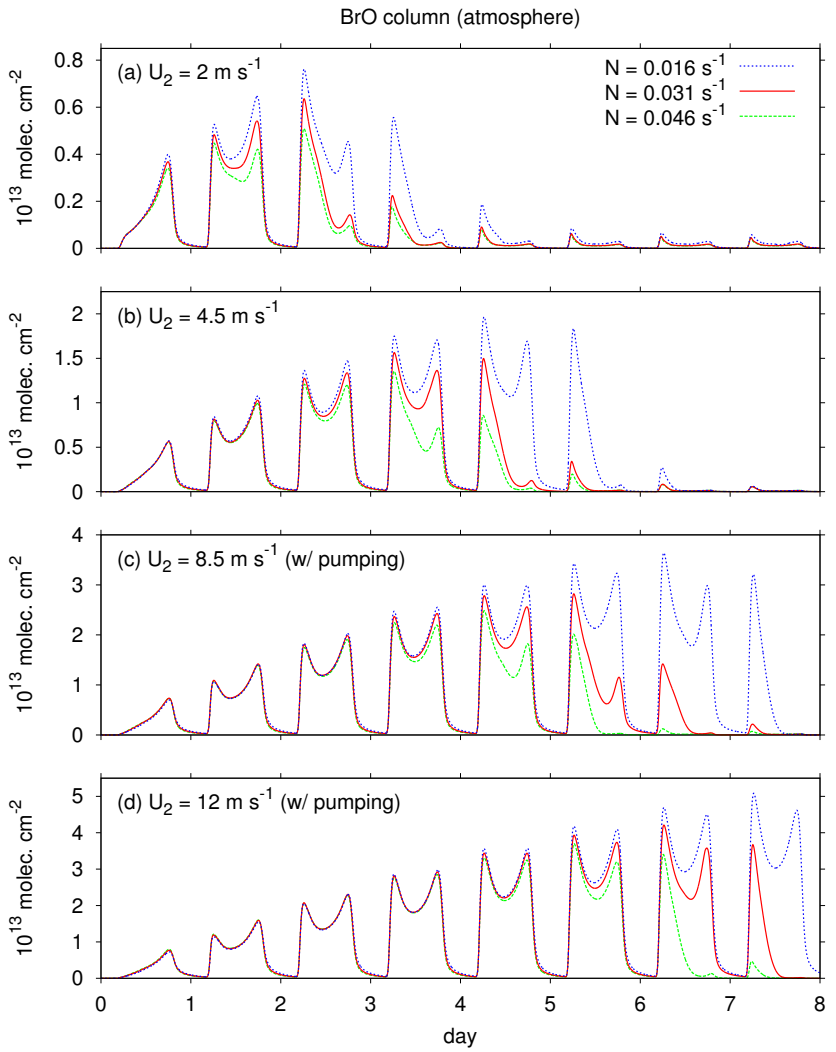

Fig. 16. Simulated column amounts of $\mathrm{BrO}$ in the atmosphere with $U_{2}$ assigned at (a) $2 \mathrm{~m} \mathrm{~s}^{-1}$, (b) $4.5 \mathrm{~m} \mathrm{~s}^{-1}$, (c) $8.5 \mathrm{~m} \mathrm{~s}^{-1}$, and (d) $12 \mathrm{~m} \mathrm{~s}^{-1}$. A sensitivity of the simulated $\mathrm{BrO}$ columns to the choice of $N\left(0.016 \mathrm{~s}^{-1}\right.$, dotted blue lines; $0.031 \mathrm{~s}^{-1}$, solid red lines; and $0.046 \mathrm{~s}^{-1}$, broken green lines) is also tested.

The profile of turbulent diffusivity in the atmosphere is diagnosed by solving a set of micro-meteorological equations applicable to the stable boundary layer. The effect of wind pumping in the SIA is superimposed on molecular diffusivity in a simplified fashion and only when the surface air flow is diagnosed to be aerodynamically rough.

By elaborating both the physics and chemistry of the atmosphere-snowpack system, the present model was able to show the significance of chemical interactions that have been largely unrecognized. Bromine release from the top $1 \mathrm{~mm}$ of the snowpack is driven by the "bromine explosion" in a conventional sense, that is, $\mathrm{HOBr}$ deposited from the atmosphere oxidizes $\mathrm{Br}^{-}$on the snow grains to release $\mathrm{Br}_{2}$, whereas, below this top layer, aqueous-phase radical chemistry and an insnow "bromine explosion" both play an important role. Both of these top- and deeper-layer processes contribute significantly to the $\mathrm{Br}_{2}$ release to the atmosphere, while the deeperlayer production is generally more important for the net outflux of gaseous bromine to build up in the ABL. Ozone is among the key species that control the rates of both conventional and in-snow bromine explosions. The aqueous-phase radical chemistry can keep operating as an efficient source of $\mathrm{Br}_{2}$ in the snowpack even after ozone is depleted, but, without assistance from the in-snow bromine explosion, the buildup of $\mathrm{Br}_{2}$ and its subsequent release to the atmosphere will diminish significantly. Within the framework of our multiphase chemical scheme, acidity of the LLL in the snowpack was also found to be a key element for controlling the activation of bromine chemistry. We also found that multiphase recycling of $\mathrm{HCl}$ could be important for buffering the acidity of the LLL. The results of our modeling study reinforce recent findings from field measurements (Pratt et al., 2013) and from laboratory experiments (Wren et al., 2013) on the roles of snow-grain acidity and "ozone enhancement" in reactive bromine release from the snowpack. As a result of the insnow bromine explosion, ozone is destroyed via bromine radical chemistry more actively in the SIA than in the ambient air, giving rise to apparent dry deposition velocities from the air to the snow on the order of $10^{-3} \mathrm{~cm} \mathrm{~s}^{-1}$ during daytime. Field studies in an attempt to determine this quantity have reported much greater values over the coastal snow cover in the springtime Arctic (Helmig et al., 2012; Muller et al., 2012), indicating either that our model is much too conservative in simulating the activity of bromine radical chemistry in the snowpack or that rapid ozone loss in/on the snow implied from those field studies was controlled by other mechanisms than simulated here.

In this study, the physical and chemical characteristics of the snowpack were assumed to be uniform over the entire depth in its initial state, although photochemical processing during model runs creates some degree of vertical profiles in the chemical composition of the model snowpack. A single exception to this assumption was a sensitivity study in which we increased the initial concentration of $\mathrm{Br}^{-} 10$ fold in the top $1 \mathrm{~mm}$ of snowpack to account for the deposition of bromine back from the atmosphere at the maturity of previous ODEs. Such a surface enhancement of snowpack $\mathrm{Br}^{-}$content was found to accelerate the net release rate of gaseous bromine from the snowpack. Here, we note that our scenario for snowpack composition assigned the initial concentrations of halide anions most likely lower by an order of magnitude or two than typically observed in snowpack on first-year sea ice and refrozen leads. Had we adopted a different snowpack composition based on these latter observations, higher loading of seawater composition in the snowpack would have increased initial $\mathrm{Br}^{-}$content on one hand, while on the other hand it would have increased alkalinity that must be titrated before gaseous bromine could be released from the snowpack efficiently, as indicated from a field study by Pratt et al. (2013). Also, stratigraphic variations in snowpack salinity are commonly observed on sea ice (Massom et al., 1998; Domine et al., 2004; Abbatt et al., 2012), evoking the same type of problem for the trade-off between bromide content and alkalinity across the vertical layers of the snowpack.

On the physical side, the snowpack normally exhibits distinct stratigraphic features in its microphysical structure 
(such as coarse-grained depth hoar, hard windpack, relatively fine-grained recent snow, and surface hoar) as a result of intermittent wind storms and post-depositional metamorphosis. Such inhomogeneity in the physical properties will certainly influence chemical processes addressed in this study by changing the permeability of air against wind pumping, the rate of reactive uptake of gases on the snow grains, and so on (Domine et al., 2008). From the exploratory nature of this study, we have chosen not to pursue these complex problems, but they should certainly be addressed in the future towards a more realistic representation of in-snow photochemical processes.

Another area of great uncertainty in our present approach relates to a question of how realistic it is to assume that impurities exist uniformly (at the scale of each snow grain) and exclusively in the LLL on the grain surface in contact with SIA to mediate multiphase reactions as well as vertical mass transfer of condensed-phase species within the snowpack. It may actually be more appropriate to represent the ice grains of natural snowpack by a heterogeneous mixture (or co-existence) of solute-rich regions, such as veins at the groves of grain boundaries and pockets inside ice matrix, and solute-less (or almost "pure") ice surfaces (e.g., Domine et al., 2013). That would call for some fundamental changes in the design of a snowpack model from our present implementation in PHANTAS.

By introducing a simplified scheme of air-snowpack chemical interaction of bromine in their 3-D model of Arctic bromine and ozone chemistry, Toyota et al. (2011) simulated the occurrence of "BrO clouds" and ODEs with reasonable success across the Arctic in April 2001. It was speculated that the success of the Toyota et al. (2011) model originated in its empirical parameterization by which a majority of bromine release on sea ice was associated with the dry deposition of ozone. This is qualitatively consistent with our finding in the present study employing much more detailed chemistry and physics in the snowpack, as we also find here that a major part of net bromine release to the atmosphere was associated with in-snow chemical processes mediated by ozone. It therefore seems useful to pursue the feasibility of incorporating key processes in the snowpack physics and chemistry from this 1-D model into large-scale 3-D models numerically in a much less demanding manner.

Finally, although it was beyond the scope of this study, wind-blown snow has been argued to be critical to the occurrence of high $\mathrm{BrO}$ levels in the polar boundary layer (e.g., Yang et al., 2008; Jones et al., 2009; Frieß et al., 2011; Buys et al., 2013). We note, however, that ODEs are observed in the $\mathrm{ABL}$ at lower wind speeds more often than at higher wind speeds. Although it is possible to explain such observations by assuming blowing/drifting snow events that could have occurred back in time of the air mass history, the present simulations indicate an efficient bromine release from snowpack even without the wind-blown snow at least in the springtime Arctic. As surmised by Jones et al. (2009), direct bromine re- lease from the surface snowpack could be a dominant source of bromine at low wind speeds, whereas the wind-blown snow could be far more effective as a bromine source at high wind speeds. Physical frameworks adopted (albeit quite differently to each other) in the models by Yang et al. (2008) and Jones et al. (2009) were highly elaborated in describing the physical processes of blowing/drifting snow, but they did not come with the same level of sophistication in the description of chemistry. For a better understanding of this problem, it is worthwhile to investigate the chemistry of wind-blown snow and its link to ODEs by using a model of multiphase chemistry as detailed as in this study for snowpack.

\section{Supplementary material related to this article is available online at http://www.atmos-chem-phys.net/14/ 4101/2014/acp-14-4101-2014-supplement.pdf.}

Acknowledgements. We thank H.-W. Jacobi, two other reviewers and the editor for their valuable comments to the manuscript. This study was supported by funding from CFCAS, OME, CFI, OIT and NSERC to York University and from the Clean Air Regulatory Agenda (CARA) at Environment Canada (EC). We also thank L. Zhang for providing a FORTRAN program to calculate dry deposition velocities of aerosols and A. Kallaur for setting up and maintaining a computing environment for KT at EC. John C. "Jack" McConnell, who had motivated and long supported this study, passed away shortly after the acceptance of the manuscript for ACPD. True to his character, he remarkably contributed to the manuscript despite his deteriorating health in the last months of his life.

Edited by: J. W. Bottenheim

\section{References}

Abbatt, J. P. D.: Interactions of atmospheric trace gases with ice surfaces: adsorption and reaction, Chem. Rev., 103, 4783-4800, 2003.

Abbatt, J., Oldridge, N., Symington, A., Chukalovskiy, V., McWhinney, R. D., Sjostedt, S., and Cox, R. A.: Release of gasphase halogens by photolytic generation of $\mathrm{OH}$ in frozen halidenitrate solutions: an active halogen formation mechanism?, J. Phys. Chem. A, 114, 6527-6533, 2010.

Abbatt, J. P. D., Thomas, J. L., Abrahamsson, K., Boxe, C., Granfors, A., Jones, A. E., King, M. D., Saiz-Lopez, A., Shepson, P. B., Sodeau, J., Toohey, D. W., Toubin, C., von Glasow, R., Wren, S. N., and Yang, X.: Halogen activation via interactions with environmental ice and snow in the polar lower troposphere and other regions, Atmos. Chem. Phys., 12, 6237-6271, doi:10.5194/acp-12-6237-2012, 2012.

Adams, J. W., Holmes, N. S., and Crowley, J. N.: Uptake and reaction of $\mathrm{HOBr}$ on frozen and dry $\mathrm{NaCl} / \mathrm{NaBr}$ surfaces between 253 and 233 K, Atmos. Chem. Phys., 2, 79-91, doi:10.5194/acp2-79-2002, 2002. 
Albert, M. R.: Modeling heat, mass, and species transport in polar firn, Ann. Glaciol., 23, 138-143, 1996.

Albert, M. R. and Shultz, E. F.: Snow and firn properties and airsnow transport processes at Summit, Greenland, Atmos. Environ., 36, 2789-2797, 2002.

Albert, M. R., Grannas, A. M., Bottenheim, J., Shepson, P. B., and Perron, F. E.: Processes and properties of snow-air transfer in the high Arctic with application to interstitial ozone at Alert, Canada, Atmos. Environ., 36, 2779-2787, 2002.

Anastasio, C. and Chu, L.: Photochemistry of nitrous acid (HONO) and nitrous acidium ion $\left(\mathrm{H}_{2} \mathrm{ONO}^{+}\right)$in aqueous solution and ice, Environ. Sci. Technol., 43, 1108-1114, 2009.

Andreas, E. L.: A theory for the scalar roughness and the scalar transfer coefficients over snow and sea ice, Bound.-Lay. Meteorol., 38, 159-184, 1987.

Andreas, E. L.: Air-ice drag coefficients in the western Weddell Sea 2. A model based on form drag and drifting snow, J. Geophys. Res., 100, 4833-4843, 1995.

Andreas, E. L., Guest, P. S., Persson, P. O. G., Fairall, C. W., Horst, T. W., Moritz, R. E., and Semmer, S. R.: Near-surface water vapor over polar sea ice is always near ice saturation, J. Geophys. Res., 107, 8033, doi:10.1029/2000JC000411, 2002.

Andreas, E. L., Jordan, R. E., Guest, P. S., Persson, P. O. G., Grachev, A. A., and Fairall, C. W.: Roughness length over snow, in: Reprints, 18th Conf. on Hydrology, 11-15 January 2004, Seattle, WA, CD-ROM, JP4.31, Amer. Meteor. Soc., 2004a.

Andreas, E. L., Jordan, R. E., and Makshtas, A. P.: Simulations of snow, ice, and near-surface atmospheric processes on Ice Station Weddell, J. Hydrometeorol., 5, 611-624, 2004b.

Ariya, P. A., Hopper, J. F., and Harris, G. W.: $\mathrm{C}_{2}-\mathrm{C}_{7}$ hydrocarbon concentrations in Arctic snowpack interstitial air: Potential presence of active Br within the snowpack, J. Atmos. Chem., 34, 5564, 1999.

Barrie, L. A., Bottenheim, J. W., Schnell, R. C., Crutzen, P. J., and Rasmussen, R. A.: Ozone destruction and photochemical reactions at polar sunrise in the lower Arctic troposphere, Nature, 334, 138-141, 1988.

Bartels-Rausch, T., Jacobi, H.-W., Kahan, T. F., Thomas, J. L., Thomson, E. S., Abbatt, J. P. D., Ammann, M., Blackford, J. R., Bluhm, H., Boxe, C., Domine, F., Frey, M. M., Gladich, I., Guzmán, M. I., Heger, D., Huthwelker, Th., Klán, P., Kuhs, W. F., Kuo, M. H., Maus, S., Moussa, S. G., McNeill, V. F., Newberg, J. T., Pettersson, J. B. C., Roeselová, M., and Sodeau, J. R.: A review of air-ice chemical and physical interactions (AICI): liquids, quasi-liquids, and solids in snow, Atmos. Chem. Phys., 14, 1587-1633, doi:10.5194/acp-14-1587-2014, 2014.

Bear, J.: Dynamics of Fluids in Porous Media, American Elsevier Publishing Co., New York, 1972.

Beine, H., Anastasio, C., Esposito, G., Patten, K., Wilkening, E., Domine, F., Voisin, D., Barret, M., Houdier, S., and Hall, S.: Soluble, light-absorbing species in snow at Barrow, Alaska, J. Geophys. Res., 116, D00R05, doi:10.1029/2011JD016181, 2011.

Blackadar, A. K.: The vertical distribution of wind and turbulent exchange in a neutral atmosphere, J. Geophys. Res., 67, 30953102, 1962.

Bluhm, H., Ogletree, D. F., Fadley, C. S., Hussain, Z., and Salmeron, M.: The premelting of ice studied with photoelectron spectroscopy, J. Phys.: Condens. Matter, 14, L227-L233, doi:10.1088/0953-8984/14/8/108, 2002.
Bottenheim, J. W., Gallant, A. G., and Brice, K. A.: Measurements of $\mathrm{NO}_{\mathrm{y}}$ species and $\mathrm{O}_{3}$ at $82^{\circ} \mathrm{N}$ latitude, Geophys. Res. Lett., 13, 113-116, 1986.

Bottenheim, J. W., Barrie, L. A., Atlas, E., Heidt, L. E., Niki, H., Rasmussen, R. A., and Shepson, P. B.: Depletion of lower tropospheric ozone during Arctic spring: the Polar Sunrise Experiment 1988, J. Geophys. Res., 95, 18555-18568, 1990.

Bottenheim, J. W., Boudries, H., Brickell, P. C., and Atlas, E.: Alkenes in the Arctic boundary layer at Alert, Nunavut, Canada, Atmos. Environ., 36, 2585-2594, 2002.

Bottenheim, J. W. and Chan, E.: A trajectory study into the origin of spring time Arctic boundary layer ozone depletion, J. Geophys. Res., 111, D19301, doi:10.1029/2006JD007055, 2006.

Bottenheim, J. W., Netcheva, S., Morin, S., and Nghiem, S. V.: Ozone in the boundary layer air over the Arctic Ocean: measurements during the TARA transpolar drift 2006-2008, Atmos. Chem. Phys., 9, 4545-4557, doi:10.5194/acp-9-4545-2009, 2009.

Boudries, H. and Bottenheim, J. W.: $\mathrm{Cl}$ and $\mathrm{Br}$ atom concentrations during a surface boundary layer ozone depletion event in the Canadian High Arctic, Geophys. Res. Lett., 27, 517-520, 2000.

Boudries, H., Bottenheim, J. W., Guimbaud, C., Grannas, A. M., Shepson, P. B., Houdier, S., Perrier, S., and Domine, F.: Distribution and trends of oxygenated hydrocarbons in the high Arctic derived from measurements in the atmospheric boundary layer and interstitial snow air during the ALERT2000 field campaign, Atmos. Environ., 36, 2573-2583, 2002.

Brost, R. A. and Wyngaard, J. C.: A model study of the stably stratified planetary boundary layer, J. Atmos. Sci., 35, 1427-1440, 1978.

Brutsaert, W.: The roughness length for water vapor, sensible heat, and other scalars, J. Atmos. Sci., 32, 2028-2031, 1975.

Businger, J. A., Wyngaard, J. C., Izumi, Y., and Bradley, E. F.: Fluxprofile relationships in the atmospheric surface layer, J. Atmos. Sci., 28, 181-189, 1971.

Buys, Z., Brough, N., Huey, L. G., Tanner, D. J., von Glasow, R., and Jones, A. E.: High temporal resolution $\mathrm{Br}_{2}, \mathrm{BrCl}$ and $\mathrm{BrO}$ observations in coastal Antarctica, Atmos. Chem. Phys., 13, 1329-1343, doi:10.5194/acp-13-1329-2013, 2013.

Calvert, J. G. and Lindberg, S. E.: The potential influence of iodinecontaining compounds on the chemistry of the troposphere in the polar spring, II. Mercury depletion, Atmos. Environ., 38, 51055116, 2004.

Carignano, M. A., Shepson, P. B., and Szleifer, I.: Ions at the ice/vapor interface, Chem. Phys. Lett., 436, 99-103, 2007.

Carver, G. D., Brown, P. D., and Wild, O.: The ASAD atmospheric chemistry integration package and chemical reaction database, Comp. Phys. Comm., 105, 197-215, 1997.

Chance, K.: Analysis of BrO measurements from the Global Ozone Monitoring Experiment, Geophys. Res. Lett., 25, 3335-3338, 1998.

Cheng, Y. and Brutsaert, W.: Flux-profile relationships for wind speed and temperature in the stable atmospheric boundary layer, Bound.-Lay. Meteorol., 114, 519-538, 2005.

Cho, H., Shepson, P. B., Barrie, L. A., Cowin, J. P., and Zaveri, R.: NMR investigation of the quasi-brine layer in ice/brine mixtures, J. Phys. Chem. B, 106, 11226-11232, 2002.

Choi, S., Wang, Y., Salawitch, R. J., Canty, T., Joiner, J., Zeng, T., Kurosu, T. P., Chance, K., Richter, A., Huey, L. G., Liao, J., 
Neuman, J. A., Nowak, J. B., Dibb, J. E., Weinheimer, A. J., Diskin, G., Ryerson, T. B., da Silva, A., Curry, J., Kinnison, D., Tilmes, S., and Levelt, P. F.: Analysis of satellite-derived Arctic tropospheric $\mathrm{BrO}$ columns in conjunction with aircraft measurements during ARCTAS and ARCPAC, Atmos. Chem. Phys., 12, 1255-1285, doi:10.5194/acp-12-1255-2012, 2012.

Chu, L. and Anastasio, C.: Quantum yields of hydroxyl radical and nitrogen dioxide from the photolysis of nitrate on ice, J. Phys. Chem. A, 107, 9594-9602, 2003.

Chu, L. and Anastasio, C.: Formation of hydroxyl radical from the photolysis of frozen hydrogen peroxide, J. Phys. Chem. A, 109, 6264-6271, 2005.

Chu, L. and Anastasio, C.: Temperature and wavelength dependence of nitrite photolysis in frozen and aqueous solutions, Environ. Sci. Technol., 41, 3626-3632, 2007.

Colbeck, S. C.: Air movement in snow due to windpumping, J. Glaciol., 35, 209-213, 1989.

Conklin, M. H. and Bales, R. C.: $\mathrm{SO}_{2}$ uptake on ice spheres: liquid nature of the ice-air interface, J. Geophys. Res., 98, 1685116855, 1993.

Cunningham, J. and Waddington, E. D.: Air flow and dry deposition of non-sea salt sulfate in polar firn: paleoclimatic implications, Atmos. Environ., 27, 2943-2956, 1993.

Dash, J. G., Fu, H., and Wettlaufer, J. S.: The premelting of ice and its environmental consequences, Rep. Prog. Phys., 58, 115-167, 1995.

Domine, F., Cabanes, A., and Legagneux, L.: Structure, microphysics, and surface area of the Arctic snowpack near Alert during the ALERT2000 campaign, Atmos. Environ., 36, 2753-2765, 2002.

Domine, F., Sparapani, R., Ianniello, A., and Beine, H. J.: The origin of sea salt in snow on Arctic sea ice and in coastal regions, Atmos. Chem. Phys., 4, 2259-2271, doi:10.5194/acp-4-2259-2004, 2004.

Domine, F., Albert, M., Huthwelker, T., Jacobi, H.-W., Kokhanovsky, A. A., Lehning, M., Picard, G., and Simpson, W. R.: Snow physics as relevant to snow photochemistry, Atmos. Chem. Phys., 8, 171-208, doi:10.5194/acp-8-171-2008, 2008.

Domine, F., Houdier, S., Taillandier, A.-S., and Simpson, W. R.: Acetaldehyde in the Alaskan subarctic snowpack, Atmos. Chem. Phys., 10, 919-929, doi:10.5194/acp-10-919-2010, 2010.

Domine, F., Bock, J., Voisin, D., and Donaldson, D. J.: Can we model snow photochemistry? Problems with the current approaches, J. Phys. Chem. A, 117, 4733-4749, 2013.

Döppenschmidt, A. and Butt, H.-J.: Measuring thickness of the liquid-like layer on ice surfaces with atomic force microscopy, Langmuir, 16, 6709-6714, 2000.

Douglas, T. A. and Sturm, M.: Arctic haze, mercury and the chemical composition of snow across northwestern Alaska, Atmos. Environ., 38, 805-820, 2004.

Douglas, T. A., Domine, F., Barret, M., Anastasio, C., Beine, H. J., Bottenheim, J., Grannas, A., Houdier, S., Netcheva, S., Rowland, G., Staebler, R., and Steffen, A.: Frost flowers growing in the Arctic ocean-atmosphere-sea ice-snow interface: 1. chemical composition, J. Geophys. Res., 117, D00R09, doi:10.1029/2011JD016460, 2012.

Dubowski, Y., Colussi, A. J., Boxe, C., and Hoffmann, M. R.: Monotonic increase of nitrite yields in the photolysis of nitrate in ice and water between 238 and 294 K, J. Phys. Chem. A, 106 , 6967-6971, 2002.

Ebinghaus, R., Kock, H. H., Temme, C., Einax, J. W., Lowe, A. G., Richter, A., Burrows, J. P., and Schroeder, W. H.: Antarctic springtime depletion of atmospheric mercury, Environ. Sci. Technol., 36, 1238-1244, 2002.

Eicken, H., Lange, M. A., and Wadhams, P.: Characteristics and distribution patterns of snow and meteoric ice in the Weddell Sea and their contribution to the mass balance of sea ice, Ann. Geophys., 12, 80-93, doi:10.1007/s00585-994-0080-x, 1994.

Elbaum, M., Lipson, S. G., and Dash, J. G.: Optical study of surface melting on ice, J. Crystal Growth, 129, 491-505, 1993.

Evans, M. J., Jacob, D. J., Atlas, E., Cantrell, C. A., Eisele, F., Flocke, F., Fried, A., Mauldin, R. L., Ridley, B. A., Wert, B., Talbot, R., Blake, D., Heikes, B., Snow, J., Walega, J., Weinheimer, A. J., and Dibb, J.: Coupled evolution of $\mathrm{BrO}_{\mathrm{x}}-\mathrm{ClO}_{\mathrm{x}}{ }^{-}$ $\mathrm{HO}_{\mathrm{x}}-\mathrm{NO}_{\mathrm{x}}$ chemistry during bromine-catalyzed ozone depletion events in the arctic boundary layer, J. Geophys. Res., 108, 8368, doi:10.1029/2002JD002732, 2003.

Fan, S.-M. and Jacob, D. J.: Surface ozone depletion in Arctic spring sustained by bromine reactions on aerosols, Nature, 359, 522-524, 1992.

Fickert, S., Adams, J. W., and Crowley, J. N.: Activation of $\mathrm{Br}_{2}$ and $\mathrm{BrCl}$ via uptake of $\mathrm{HOBr}$ onto aqueous salt solutions, J. Geophys. Res., 104, 23719-23727, 1999.

Fisher, J. A., Jacob, D. J., Wang, Q., Bahreini, R., Carouge, C. C., Cubison, M. J., Dibb, J. E., Diehl, T., Jimenez, J. L., Leibensperger, E. M., Lu, Z., Meinders, M. B., Pye, H. O., Quinn, P. K., Sharma, S., Streets, D. G., van Donkelaar, A., and Yantosca, R. M.: Sources, distribution, and acidity of sulfateammonium aerosol in the Arctic in winter-spring, Atmos. Environ., 45, 7301-7318, 2011.

Foster, K. L., Plastridge, R. A., Bottenheim, J. W., Shepson, P. B., Finlayson-Pitts, B. J., and Spicer, C. W.: The role of $\mathrm{Br}_{2}$ and $\mathrm{BrCl}$ in surface ozone destruction at polar sunrise, Science, 291, 471-474, 2001.

Frieß, U., Wagner, T., Pundt, I., Pfeilsticker, K., and Platt, U.: Spectroscopic measurements of tropospheric iodine oxide at Neumayer Station, Antarctica, Geophys. Res. Lett., 28, 1941-1944, 2001.

Frieß, U., Hollwedel, J., Koönig-Langlo, G., Wagner, T., and Platt, U.: Dynamics and chemistry of tropospheric bromine explosion events in the Antarctic coastal region, J. Geophys. Res. 109, D06305, doi:10.1029/2003JD004133, 2004.

Frieß, U., Sihler, H., Sander, R., Pöhler, D., Yilmaz, S., and Platt, U.: The vertical distribution of $\mathrm{BrO}$ and aerosols in the Arctic: measurements by active and passive differential optical absorption spectroscopy, J. Geophys. Res., 116, D00R04, doi:10.1029/2011JD015938, 2011.

Furukawa, Y. and Nada, H.: Anisotropic surface melting of an ice crystal and its relationship to growth forms, J. Phys. Chem. B, 101, 6167-6170, 1997.

Fuller, E. N., Schettle, P. D., and Giddings, J. C.: A new method for prediction of binary gas-phase diffusion coefficients, Ind. Eng. Chem., 58, 19-27, 1966.

Fuller, E. N., Ensley, K., and Giddings, J. C.: Diffusion of halogenated hydrocarbons in helium, effect of structure on collision cross sections, J. Phys. Chem., 73, 3679-3685, 1969. 
Garratt, J. R.: The Atmospheric Boundary Layer, Cambridge Univ. Press, Cambridge, UK, 1992.

Gjessing, Y. T.: Episodic variations of snow contamination of an Arctic snowfield, Atmos. Environ., 11, 643-647, 1977.

Gladich, I., Pfalzgraff, W., Maršálek, O., Jungwirth, P., Roselová, M., and Neshyba, S.: Arrhenius analysis of anisotropic surface self-diffusion on the prismatic facet of ice, Phys. Chem. Chem. Phys., 13, 19960-19969, 2011.

Goff, J. A.: Saturation pressure of water on the new Kelvin scale, Transactions of the American Society of Heating and AirConditioning Engineers, 63, 347-354, 1957.

Grannas, A. M., Shepson, P. B., Guimbaud, C., Sumner, A. L., Albert, M., Simpson, W., Dominé, F., Boudries, H., Bottenheim, J., Beine, H. J., Honrath, R., and Zhou, X.: A study of photochemical and physical processes affecting carbonyl compounds in the Arctic atmospheric boundary layer, Atmos. Environ., 36, 27332742, 2002.

Grannas, A. M., Shepson, P. B., and Filley, T. R.: Photochemistry and nature of organic matter in Arctic and Antarctic snow, Global Biogeochem. Cy., 18, GB1006, doi:10.1029/2003GB002133, 2004.

Grannas, A. M., Jones, A. E., Dibb, J., Ammann, M., Anastasio, C., Beine, H. J., Bergin, M., Bottenheim, J., Boxe, C. S., Carver, G., Chen, G., Crawford, J. H., Dominé, F., Frey, M. M., Guzmán, M. I., Heard, D. E., Helmig, D., Hoffmann, M. R., Honrath, R. E., Huey, L. G., Hutterli, M., Jacobi, H. W., Klán, P., Lefer, B., McConnell, J., Plane, J., Sander, R., Savarino, J., Shepson, P. B., Simpson, W. R., Sodeau, J. R., von Glasow, R., Weller, R., Wolff, E. W., and Zhu, T.: An overview of snow photochemistry: evidence, mechanisms and impacts, Atmos. Chem. Phys., 7, 4329-4373, doi:10.5194/acp-7-4329-2007, 2007.

Guimbaud, C., Grannas, A. M., Shepson, P. B., Fuentes, J. D., Boudries, H., Bottenheim, J. W., Dominé, F., Houdier, S., Perrier, S., Biesenthal, T. B., and Splawn, B. G.: Snowpack processing of acetaldehyde and acetone in the Arctic atmospheric boundary layer, Atmos. Environ., 36, 2743-2752, 2002.

Haag, W. R. and Hoigné, J.: Ozonation of bromide-containing waters: kinetics of formation of hypobromous acid and bromate, Environ. Sci. Technol., 17, 261-267, 1983.

Harder, S. L., Warren, S. G., Charlson, R. J., and Covert, D. S.: Filtering of air through snow as a mechanism for aerosol deposition to the Antarctic ice sheet, J. Geophys. Res., 101, 18729-18743, doi:10.1029/96JD01174, 1996.

Hausmann, M. and Platt, U.: Spectroscopic measurement of bromine oxide and ozone in the high Arctic during Polar Sunrise Experiment 1992, J. Geophys. Res., 99, 25399-25413, 1994.

Helmig, D., Bocquet, F., Cohen, L., and Oltmans, S. J.: Ozone uptake to the polar snowpack at Summit, Greenland, Atmos. Environ., 41, 5061-5076, 2007a.

Helmig, D., Ganzeveld, L., Butler, T., and Oltmans, S. J.: The role of ozone atmosphere-snow gas exchange on polar, boundary-layer tropospheric ozone - a review and sensitivity analysis, Atmos. Chem. Phys., 7, 15-30, doi:10.5194/acp-7-15-2007, 2007b.

Helmig, D., Boylan, P., Johnson, B., Oltmans, S., Fairall, C., Staebler, R., Weinheimer, A., Orlando, J., Knapp, D. J., Montzka, D. D., Flocke, F., Frieß, U., Sihler, H., and Shepson, P. B.: Ozone dynamics and snow-atmosphere exchanges during ozone depletion events at Barrow, Alaska, J. Geophys. Res., 117, D20303, doi:10.1029/2012JD017531, 2012.
Herrmann, H., Majdik, Z., Ervens, B., and Weise, D.: Halogen production from aqueous tropospheric particles, Chemosphere, 52, 485-502, 2003.

Hindmarsh, A. C.: ODEPACK, a systematized collection of ode solvers, in: Scientific Computing, edited by: Stepleman, R. S., Carver, M., Peskin, R., Ames, W. F., and Vichnevetsky, W. F., North-Holland, Amsterdam, 55-64, 1983.

Hirdman, D., Aspmo, K., Burkhart, J. F., Eckhardt, S., Sodemann, H., and Stohl, A.: Transport of mercury in the Arctic atmosphere: evidence for a spring-time net sink and summer-time source, Geophys. Res. Lett., 36, L12814, doi:10.1029/2009GL038345, 2009.

Hopper, J. F. and Hart, W.: Meteorological aspects of the 1992 Polar Sunrise Experiment, J. Geophys. Res., 99, 25315-25328, 1994.

Hopper, J. F., Barrie, L. A., Silis, A., Hart, W., Gallant, A. J., and Dryfhout, H.: Ozone and meteorology during the 1994 Polar Sunrise Experiment, J. Geophys. Res., 103, 1481-1492, 1998.

Huff, A. K. and Abbatt, J. P. D.: Kinetics and product yields in the heterogeneous reactions of $\mathrm{HOBr}$ with ice surfaces containing $\mathrm{NaBr}$ and $\mathrm{NaCl}$, J. Phys. Chem. A, 106, 5279-5287, 2002.

Jacobi, H.-W., Kaleschke, L., Richter, A., Rozanov, A., and Burrows, J. P.: Observation of a fast ozone loss in the marginal ice zone of the Arctic Ocean, J. Geophys. Res., 111, D15309, doi:10.1029/2005JD006715, 2006.

Jacobi, H.-W., Morin, S., and Bottenheim, J. W.: Observation of widespread depletion of ozone in the springtime boundary layer of the central Arctic linked to mesoscale synoptic conditions, J. Geophys. Res., 115, D17302, doi:10.1029/2010JD013940, 2010.

Jacobi, H. W., Voisin, D., Jaffrezo, J. L., Cozic, J., and Douglas, T. A.: Chemical composition of the snowpack during the OASIS spring campaign 2009 at Barrow, Alaska, J. Geophys. Res., 117, D00R13, doi:10.1029/2011JD016654, 2012.

Jobson, B. T., Niki, H., Yokouchi, Y., Bottenheim, J., Hopper, F., and Leaitch, R.: Measurements of $\mathrm{C}_{2}-\mathrm{C}_{6}$ hydrocarbons during the Polar Sunrise 1992 Experiment: evidence for $\mathrm{Cl}$ atom and $\mathrm{Br}$ atom chemistry, J. Geophys. Res., 99, 25355-25368, 1994.

Johnson, K. P., Blum, J. D., Keeler, G. J., and Douglas, T. A.: Investigation of the deposition and emission of mercury in arctic snow during an atmospheric mercury depletion event, J. Geophys. Res., 113, D17304, doi:10.1029/2008JD009893, 2008.

Jones, A. E., Anderson, P. S., Begoin, M., Brough, N., Hutterli, M. A., Marshall, G. J., Richter, A., Roscoe, H. K., and Wolff, E. W.: BrO, blizzards, and drivers of polar tropospheric ozone depletion events, Atmos. Chem. Phys., 9, 4639-4652, doi:10.5194/acp-9-4639-2009, 2009.

Jones, A. E., Anderson, P. S., Wolff, E. W., Roscoe, H. K., Marshall, G. J., Richter, A., Brough, N., and Colwell, S. R.: Vertical structure of Antarctic tropospheric ozone depletion events: characteristics and broader implications, Atmos. Chem. Phys., 10, 7775-7794, doi:10.5194/acp-10-7775-2010, 2010.

Kaleschke, L., Richter, A., Burrows, J., Afe, O., Heygster, G., Notholt, J., Rankin, A. M., Roscoe, H. K., Hollwedel, J., Wagner, T., and Jacobi, H. W.: Frost flowers on sea ice as a source of sea salt and their influence on tropospheric halogen chemistry, Geophys. Res. Lett., 31, L16114, doi:10.1029/2004GL020655, 2004.

Keene, W. C., Pszenny, A. A. P., Maben, J. R., and Sander, R.: Variation of marine aerosol acidity with particle size, Geophys. Res. Lett., 29, 5-1-5-4, doi:10.1029/2001GL013881, 2002. 
Keil, A. D. and Shepson, P. B.: Chlorine and bromine atom ratios in the springtime Arctic troposphere as determined from measurements of halogenated volatile organic compounds, J. Geophys. Res., 111, D17303, doi:10.1029/2006JD007119, 2006.

King, M. D. and Simpson, W. R.: Extinction of UV radiation in Arctic snow at Alert, Canada $\left(82^{\circ} \mathrm{N}\right)$, J. Geophys. Res., 106, 12499 12507, 2001.

Koop, T., Kapilashrami, A., Molina, L. T., and Molina, M. J.: Phase transitions of sea-salt/water mixtures at low temperatures: Implications for ozone chemistry in the polar marine boundary layer, $\mathrm{J}$. Geophys. Res., 105, 26393-26402, 2000.

Krnavek, L., Simpson, W. R., Carlson, D., Domine, F., Douglas, T. A., and Sturm, M.: The chemical composition of surface snow in the Arctic: Examining marine, terrestrial, and atmospheric influences, Atmos. Environ., 50, 349-359, 2012.

Kuo, M. H., Moussa, S. G., and McNeill, V. F.: Modeling interfacial liquid layers on environmental ices, Atmos. Chem. Phys., 11, 9971-9982, doi:10.5194/acp-11-9971-2011, 2011.

Kylling, A., Stamnes, K., and Tsay, S.-C.: A reliable and efficient two-stream algorithm for spherical radiative transfer: documentation of accuracy in realistic layered media, J. Atmos. Chem., 21, 115-150, 1995.

Laird, S. K., Buttry, D. A., and Sommerfeld, R. A.: Nitric acid adsorption on ice: surface diffusion, Geophys. Res. Lett., 26, 699$701,1999$.

Lehrer, E., Hönninger, G., and Platt, U.: A one dimensional model study of the mechanism of halogen liberation and vertical transport in the polar troposphere, Atmos. Chem. Phys., 4, 24272440, doi:10.5194/acp-4-2427-2004, 2004.

Li, S.-M.: Equilibrium of particle nitrite with gas-phase HONO: tropospheric measurements in the high arctic during polar sunrise, $\mathrm{J}$. Geophys. Res., 99, 25469-25478, 1994.

Liao, J., Sihler, H., Huey, L. G., Neuman, J. A., Tanner, D. J., Friess, U., Platt, U., Flocke, F. M., Orlando, J. J., Shepson, P. B., Beine, H. J., Weinheimer, A. J., Sjostedt, S. J., Nowak, J. B., Knapp, D. J., Staebler, R. M., Zheng, W., Sander, R., Hall, S. R., and Ullmann, K.: A comparison of Arctic BrO measurements by chemical ionization mass spectrometry and long path differential optical absorption spectroscopy, J. Geophys. Res., 116, D00R02, doi:10.1029/2010JD014788, 2011.

Liao, J., Huey, L. G., Liu, Z., Tanner, D. J., Cantrell, C. A., Orlando, J. J., Flocke, F. M., Shepson, P. B., Weinheimer, A. J., Hall, S. R., Ullmann, K., Beine, H. J., Wang, Y., Ingall, E. D., Stephens, C. R., Hornbrook, R. S., Apel, E. C., Riemer, D., Fried, A., Mauldin III, R. L., Smith, J. N., Staebler, R. M. Neuman J. A., and Nowak, J. B.: High levels of molecular chlorine in the Arctic atmosphere, Nature Geosci., 7, 91-94, doi:10.1038/ngeo2046, 2014

Mahajan, A. S., Shaw, M., Oetjen, H., Hornsby, K. E., Carpenter, L. J., Kaleschke, L., Tian-Kunze, X., Lee, J. D., Moller, S. J., Edwards, P., Commane, R., Ingham, T., Heard, D. E., and Plane, J. M. C.: Evidence of reactive iodine chemistry in the Arctic boundary layer, J. Geophys. Res., 115, D20303, doi:10.1029/2009JD013665, 2010.

Mahrt, L.: The near-calm stable boundary layer, Bound.-Lay. Meteorol., 140, 343-360, 2011.

Marion, G. M. and Farren, R. E.: Mineral solubilities in the Na$\mathrm{K}-\mathrm{Mg}-\mathrm{Ca}-\mathrm{Cl}-\mathrm{SO}_{4}-\mathrm{H}_{2} \mathrm{O}$ system: a re-evaluation of the sulfate chemistry in the Spencer-Møller-Weare model, Geochim. Cosmochim. Ac., 63, 1305-1318, 1999.

Massom, R. A., Lytle, V. I., Worby, A. P., and Allison, I.: Winter snow cover variability on East Antarctic sea ice, J. Geophys. Res., 103, 24837-24855, 1998.

Matthew, B. M., George, I., and Anastasio, C.: Hydroperoxyl radical $\left(\mathrm{HO}_{2} \cdot\right)$ oxidizes dibromide radical anion $\left(\cdot \mathrm{Br}_{2}^{-}\right)$to bromine $\left(\mathrm{Br}_{2}\right)$ in aqueous solution: implications for the formation of $\mathrm{Br}_{2}$ in the marine boundary layer, Geophys. Res. Lett., 30, 2297, doi:10.1029/2003GL018572, 2003.

McConnell, J. C., Henderson, G. S., Barrie, L., Bottenheim, J., Niki, H., Langford, C. H., and Templeton, E. M. J.: Photochemical bromine production implicated in Arctic boundary-layer ozone depletion, Nature, 355, 150-152, 1992.

McElroy, C. T., McLinden, C. A., and McConnell, J. C.: Evidence for bromine monoxide in the free troposphere during the Arctic polar sunrise, Nature, 397, 338-341, 1999.

McNeill, V. F., Loerting, T., Geiger, F. M., Trout, B. L., and Molina, M. J.: Hydrogen chloride-induced surface disordering on ice, P. Natl. Acad. Sci. USA, 103, 9422-9427, 2006.

Michalowski, B. A., Francisco, J. S., Li, S. M., Barrie, L. A., Bottenheim, J. W., and Shepson, P. B.: A computer model study of multiphase chemistry in the Arctic boundary layer during polar sunrise, J. Geophys. Res., 105, 15131-15145, 2000.

Millero, F. J., Feistel, R., Wright, D. G., and McDougall, T. J.: The composition of standard seawater and the definition of the reference-composition salinity scale, Deep-Sea Res. I, 55, 5072,2008

Moore, C. W., Obrist, D., Steffen, A., Staebler, R. M., Douglas, T. A., and Nghiem, S. V.: Convective forcing of mercury and ozone in the Arctic boundary layer induced by leads in sea ice, Nature, 506, 81--84, doi:10.1038/nature12924, 2014.

Morin, S., Hönninger, G., Staebler, R. M., and Bottenheim, J. W. A high time resolution study of boundary layer ozone chemistry and dynamics over the Arctic Ocean near Alert, Nunavut, Geophys. Res. Lett., 32, L08809, doi:10.1029/2004GL022098, 2005.

Muller, J. B., Dorsey, J. R., Flynn, M., Gallagher, M. W., and Dudley E. Shallcross, C. J. P., Archibald, A., Roscoe, H. K., Obbard, R. W., Atkinson, H. M., Lee, J. D., Moller, S. J., and Carpenter, L. J.: Energy and ozone fluxes over sea ice, Atmos. Environ., 47, 218-225, 2012.

Murphy, D. M. and Koop, T.: Review of the vapour pressures of ice and supercooled water for atmospheric applications, Q. J. Roy. Meteor. Soc., 131, 1539-1565, doi:10.1256/qj.04.94, 2005.

Obbard, R. W., Roscoe, H. K., Wolff, E. W., and Atkinson, H. M.: Frost flower surface area and chemistry as a function of salinity and temperature, J. Geophys. Res., 114, D20305, doi:10.1029/2009JD012481, 2009.

Oldridge, N. W. and Abbatt, J. P. D.: Formation of gas-phase bromine from interaction of ozone with frozen and liquid $\mathrm{NaCl} / \mathrm{NaBr}$ solutions: quantitative separation of surficial chemistry from bulk-phase reaction, J. Phys. Chem. A, 115, 25902598, 2011.

Oltmans, S. J.: Surface ozone measurements in clean air, J. Geophys. Res., 86, 1174-1180, 1981

Persson, P. O. G., Fairall, C. W., Andreas, E. L., Guest, P. S., and Perovich, D. K.: Measurements near the atmospheric surface flux group tower at SHEBA: near-surface conditions 
and surface energy budget, J. Geophys. Res., 107, 8045, doi:10.1029/2000JC000705, 2002.

Peterson, M. and Honrath, R.: Observations of rapid photochemical destruction of ozone in snowpack interstitial air, Geophys. Res. Lett., 28, 511-514, 2001.

Peterson, M., Barber, D., and Green, S.: Monte Carlo modeling and measurements of actinic flux levels in Summit, Greenland snowpack, Atmos. Environ., 36, 2545-2551, 2002.

Petroff, A. and Zhang, L.: Development and validation of a size-resolved particle dry deposition scheme for application in aerosol transport models, Geosci. Model Dev., 3, 753-769, doi:10.5194/gmd-3-753-2010, 2010.

Piot, M. and von Glasow, R.: The potential importance of frost flowers, recycling on snow, and open leads for ozone depletion events, Atmos. Chem. Phys., 8, 2437-2467, doi:10.5194/acp-82437-2008, 2008.

Pisso, I., Real, E., Law, K. S., Legras, B., Bousserez, N., Attié, J. L., and Schlager, H.: Estimation of mixing in the troposphere from Lagrangian trace gas reconstructions during longrange pollution plume transport, J. Geophys. Res., 114, D19301, doi:10.1029/2008JD011289, 2009.

Platt, U. and Lehrer, E.: Arctic Tropospheric Ozone Chemistry, ARCTOC, Final Report of the EU-Project No. EV5V-CT930318, Heidelberg, 1996.

Pöhler, D., Vogel, L., Frieß, U., and Platt, U.: Observation of halogen species in the Amundsen Gulf, Arctic, by active long-path differential optical absorption spectroscopy, P. Natl. Acad. Sci., 107, 6582-6587, doi:10.1073/pnas.0912231107, 2010.

Pratt, K. A., Custard, K. D., Shepson, P. B., Douglas, T. A., Pöhler, D., General, S., Zielcke, J., Simpson, W. R., Platt, U., Tanner, D. J., Huey, L. G., Carlsen, M., and Stirm, B. H.: Photochemical production of molecular bromine in Arctic surface snowpacks, Nature Geosci., 6, 351-356, doi:10.1038/ngeo1779, 2013.

Press, W. H., Flannery, B. P., Teukolsky, S. A., and Vetterling, W. T.: Numerical Recipes in FORTRAN 77: the Art of Scientific Computing, 2nd edn., Cambridge Univ. Press, Cambridge, UK, 1992.

Qiu, R., Green, S. A., Honrath, R. E., Peterson, M. C., Lu, Y., and Dziobak, M.: Measurements of $J_{\mathrm{NO}_{3}^{-}}$in snow by nitrate-based actinometry, Atmos. Environ., 36, 2563-2571, 2002.

Quinn, P. K., Shaw, G., Andrews, E., Dutton, E. G., RuohoAirola, T., and Gong, S. L.: Arctic haze: current trends and knowledge gaps, Tellus B, 59, 99-114, 2007.

Ramacher, B., Rudolph, J., and Koppmann, R.: Hydrocarbon measurements during tropospheric ozone depletion events: evidence for halogen atom chemistry, J. Geophys. Res., 104, 3633-3653, 1999.

Rankin, A. M., Wolff, E. W., and Martin, S.: Frost flowers: implications for tropospheric chemistry and ice core interpretation, J. Geophys. Res., 107, 4683, doi:10.1029/2002JD002492, 2002.

Real, E., Pisso, I., Law, K. S., Legras, B., Bousserez, N., Schlager, H., Roiger, A., and Attié, J. L.: Toward a novel highresolution modeling approach for the study of chemical evolution of pollutant plumes during long-range transport, J. Geophys. Res., 115, D12302, doi:10.1029/2009JD011707, 2010.

Reay, H. J., France, J. L., and King, M. D.: Decreased albedo, efolding depth and photolytic $\mathrm{OH}$ radical and $\mathrm{NO}_{2}$ production with increasing black carbon content in Arctic snow, J. Geophys. Res., 117, D00R20, doi:10.1029/2011JD016630, 2012.
Richter, A., Wittrock, F., Eisinger, M., and Burrows, J. P.: GOME observations of tropospheric $\mathrm{BrO}$ in northern hemispheric spring and summer 1997, Geophys. Res. Lett., 25, 2683-2686, 1998.

Saiz-Lopez, A., Mahajan, A. S., Salmon, R. A., Bauguitte, S. J.-B., Jones, A. E., Roscoe, H. K., and Plane, J. M. C.: Boundary layer halogens in coastal Antarctica, Science, 317, 348-351, 2007.

Saiz-Lopez, A., Plane, J. M. C., Mahajan, A. S., Anderson, P. S., Bauguitte, S. J.-B., Jones, A. E., Roscoe, H. K., Salmon, R. A., Bloss, W. J., Lee, J. D., and Heard, D. E.: On the vertical distribution of boundary layer halogens over coastal Antarctica: implications for $\mathrm{O}_{3}, \mathrm{HO}_{\mathrm{x}}, \mathrm{NO}_{\mathrm{x}}$ and the $\mathrm{Hg}$ lifetime, Atmos. Chem. Phys., 8, 887-900, doi:10.5194/acp-8-887-2008, 2008.

Salawitch, R. J., Canty, T., Kurosu, T., Chance, K., Liang, Q.,da Silva, A., Pawson, S., Nielsen, J. E., Rodriguez, J., Bhartia, P., Liu, X., Huey, L., Liao, J., Stickel, R., Simpson, W., Donohoue, D., Weinheimer, A., Flocke, F., Knapp, D., Montzka, D., Neuman, J., Nowak, J., Ryerson, T., Oltmans, S., Blake, D., Atlas, E. L., Kinnison, D., Tilmes, S., Pan, L., Hendrick, F., Roozendael, M. V., Kreher, K., Johnston, P., Gao, R. S., Johnson, B., Bui, T., Chen, G., Pierce, R. B., Crawford, J. H., and Jacob, D. J.: A new interpretation of total column BrO during Arctic Spring, Geophys. Res. Lett., 37, L21805, doi:10.1029/2010GL043798, 2010.

Sander, R. and Bottenheim, J.: A compilation of tropospheric measurements of gas-phase and aerosol chemistry in polar regions, Earth Syst. Sci. Data, 4, 215-282, doi:10.5194/essd-4-215-2012, 2012.

Sander, R., Vogt, R., Harris, G. W., and Crutzen, P. J.: Modeling the chemistry of ozone, halogen compounds, and hydrocarbons in the arctic troposphere during spring, Tellus B, 49, 522-532, 1997.

Sander, R., Burrows, J., and Kaleschke, L.: Carbonate precipitation in brine - a potential trigger for tropospheric ozone depletion events, Atmos. Chem. Phys., 6, 4653-4658, doi:10.5194/acp-64653-2006, 2006.

Schroeder, W. H., Anlauf, K. G., Barrie, L. A., Lu, J. Y., Steffen, A.,Schneeberger, D. R., and Berg, T.: Arctic springtime depletion of mercury, Nature, 394, 331-332, 1998.

Schumann, U., Konopka, P., Baumann, R., Busen, R., Gertz, T., Schlager, H., Schulte, P., and Volkert, H.: Estimate of diffusion parameters of aircraft exhaust plumes near the tropopause from nitric oxide ond turbulence measurements, J. Geophys. Res., 100, 14147-14162, 1995.

Schwartz, S. E.: Mass-transport considerations pertinent to aqueous phase reactions of gases in liquid-water clouds, in: Chemistry of Multiphase Atmospheric Systems, edited by: Jaeschke, W., Springer-Verlag, New York, 415-471, 1986.

Seabrook, J. A., Whiteway, J., Staebler, R. M., Bottenheim, J. W., Komguem, L., Gray, L. H., Barber, D., and Asplin, M.: LIDAR measurements of Arctic boundary layer ozone depletion events over the frozen Arctic Ocean, J. Geophys. Res., 116, D00S02, doi:10.1029/2011JD016335, 2011.

Seabrook, J. A., Whiteway, J. A., Gray, L. H., Staebler, R., and Herber, A.: Airborne lidar measurements of surface ozone depletion over Arctic sea ice, Atmos. Chem. Phys., 13, 6023-6029, doi:10.5194/acp-13-6023-2013, 2013.

Seinfeld, J. H. and Pandis, S. N.: Atmospheric Chemistry and Physics: From Air Pollution to Climate Change, J. Wiley, New York, 1998. 
Semb, A., Brækkan, R., and Joranger, E.: Major ions in Spitsbergen snow samples, Geophys. Res. Lett., 11, 445-448, 1984.

Sihler, H., Platt, U., Beirle, S., Marbach, T., Kühl, S., Dörner, S., Verschaeve, J., Frieß, U., Pöhler, D., Vogel, L., Sander, R., and Wagner, T.: Tropospheric BrO column densities in the Arctic derived from satellite: retrieval and comparison to ground-based measurements, Atmos. Meas. Tech., 5, 27792807, doi:10.5194/amt-5-2779-2012, 2012.

Simpson, W. R., King, M. D., Beine, H. J., Honrath, R. E., and Zhou, X.: Radiation-transfer modeling of snow-pack photochemical processes during ALERT 2000, Atmos. Environ., 36, 26632670, 2002.

Simpson, W. R., Alvarez-Aviles, L., Douglas, T. A., Sturm, M., and Domine, F.: Halogens in the coastal snow pack near Barrow, Alaska: evidence for active bromine air-snow chemistry during springtime, Geophys. Res. Lett., 32, L04811, doi:10.1029/2004GL021748, 2005.

Simpson, W. R., von Glasow, R., Riedel, K., Anderson, P., Ariya, P., Bottenheim, J., Burrows, J., Carpenter, L. J., Frieß, U., Goodsite, M. E., Heard, D., Hutterli, M., Jacobi, H.-W., Kaleschke, L., Neff, B., Plane, J., Platt, U., Richter, A., Roscoe, H., Sander, R., Shepson, P., Sodeau, J., Steffen, A., Wagner, T., and Wolff, E.: Halogens and their role in polar boundary-layer ozone depletion, Atmos. Chem. Phys., 7, 4375-4418, doi:10.5194/acp-7-43752007, 2007.

Smith, R. S. and Kay, B. D.: The existence of supercooled liquid water at $150 \mathrm{~K}$, Nature, 398, 788-791, 1999.

Staebler, R. M., den Hartog, G., Giorgi, B., and Düsterdiek, T.: Aerosol size distributions in Arctic haze during the Polar Sunrise Experiment 1992, J. Geophys. Res., 99, 25429-25437, 1994.

Staebler, R., Toom-Sauntry, D., Barrie, L., Langendörfer, U., Lehrer, E., Li, S.-M., and Dryfhout-Clark, H.: Physical and chemical characteristics of aerosols at Spitsbergen in the spring of 1996, J. Geophys. Res., 104, 5515-5529, 1999.

Steeneveld, G. J., van de Wiel, B. J. H., and Holtslag, A. A. M.: Diagnostic equations for the stable boundary layer heights: evaluation and dimensional analysis, J. Appl. Meteorol. Clim., 46, 212-225, 2007.

Steffen, A., Douglas, T., Amyot, M., Ariya, P., Aspmo, K., Berg, T., Bottenheim, J., Brooks, S., Cobbett, F., Dastoor, A., Dommergue, A., Ebinghaus, R., Ferrari, C., Gardfeldt, K., Goodsite, M. E., Lean, D., Poulain, A. J., Scherz, C., Skov, H., Sommar, J., and Temme, C.: A synthesis of atmospheric mercury depletion event chemistry in the atmosphere and snow, Atmos. Chem. Phys., 8, 1445-1482, doi:10.5194/acp-8-1445-2008, 2008.

Stokes, R. H. and Robinson, R. A.: Interactions in aqueous nonelectrolyte solutions, I. Solute-solvent equilibria, J. Phys. Chem., 70, 2126-2130, 1966.

Sturm, M., Holmgren, J., and Perovich, D. K.: Winter snow cover on the sea ice of the Arctic Ocean at the Surface Heat Budget of the Arctic Ocean (SHEBA): temporal evolution and spatial variability, J. Geophys. Res., 107, 8047, doi:10.1029/2000JC000400, 2002

Tang, I. N.: Chemical and size effects of hygroscopic aerosols on light scattering coefficients, J. Geophys. Res., 101, 1924519250, 1996.
Tang, I. N.: Thermodynamic and optical properties of mixed-salt aerosols of atmospheric importance, J. Geophys. Res., 102, 1883-1893, 1997.

Tang, I. N. and Munkelwitz, H. R.: Water activities, densities, and refractive indices of aqueous sulfates and sodium nitrate droplets of atmospheric importance, J. Geophys. Res., 99, 18801-18808, 1994.

Tang, T. and McConnell, J. C.: Autocatalytic release of bromine from Arctic snow pack during polar sunrise, Geophys. Res. Lett., 23, 2633-2636, 1996.

Tarasick, D. W. and Bottenheim, J. W.: Surface ozone depletion episodes in the Arctic and Antarctic from historical ozonesonde records, Atmos. Chem. Phys., 2, 197-205, doi:10.5194/acp-2197-2002, 2002.

Theys, N., Van Roozendael, M., Hendrick, F., Yang, X., De Smedt, I., Richter, A., Begoin, M., Errera, Q., Johnston, P. V., Kreher, K., and De Mazière, M.: Global observations of tropospheric BrO columns using GOME-2 satellite data, Atmos. Chem. Phys., 11, 1791-1811, doi:10.5194/acp-11-1791-2011, 2011.

Thomas, J. L., Stutz, J., Lefer, B., Huey, L. G., Toyota, K., Dibb, J. E., and von Glasow, R.: Modeling chemistry in and above snow at Summit, Greenland - Part 1: Model description and results, Atmos. Chem. Phys., 11, 4899-4914, doi:10.5194/acp-11-4899-2011, 2011.

Toom-Sauntry, D. and Barrie, L. A.: Chemical composition of snowfall in the high Arctic: 1990-1994, Atmos. Environ., 36, 2683-2693, 2002

Toyota, K., Kanaya, Y., Takahashi, M., and Akimoto, H.: A box model study on photochemical interactions between VOCs and reactive halogen species in the marine boundary layer, Atmos. Chem. Phys., 4, 1961-1987, doi:10.5194/acp-4-1961-2004, 2004.

Toyota, K., McConnell, J. C., Lupu, A., Neary, L., McLinden, C. A., Richter, A., Kwok, R., Semeniuk, K., Kaminski, J. W., Gong, S.L., Jarosz, J., Chipperfield, M. P., and Sioris, C. E.: Analysis of reactive bromine production and ozone depletion in the Arctic boundary layer using 3-D simulations with GEM-AQ: inference from synoptic-scale patterns, Atmos. Chem. Phys., 11, 3949 3979, doi:10.5194/acp-11-3949-2011, 2011.

Toyota, K., Dastoor, A. P., and Ryzhkov, A.: Air-snowpack exchange of bromine, ozone and mercury in the springtime Arctic simulated by the 1-D model PHANTAS - Part 2: Mercury and its speciation, Atmos. Chem. Phys., 14, 4135-4167, doi:10.5194/acp-14-4135-2014, 2014.

Tuckermann, M., Ackermann, R., Göltz, C., Lorenzen-Schmidt, H., Senne, T., Stutz, J., Trost, B., Unold, W., and Platt, U.: DOASobservation of halogen radical-catalysed arctic boundary layer ozone destruction during the ARCTOC-campaigns 1995 and 1996 in Ny-Ålesund, Spitsbergen, Tellus B, 49, 533-555, 1997.

Voisin, D., Jaffrezo, J.-L., Houdier, S., Barret, M., Cozic, J., King, M. D., France, J. L., Reay, H. J., Grannas, A., Kos, G., Ariya, P. A., Beine, H. J., and Domine, F.: Carbonaceous species and humic like substances (HULIS) in Arctic snowpack during OASIS field campaign in Barrow, J. Geophys. Res., 117, D00R19, doi:10.1029/2011JD016612, 2012.

Voss, L. F., Henson, B. F., Wilson, K. R., and Robinson, J. M.: Atmospheric impact of quasiliquid layers on ice surfaces, Geophys. Res. Lett., 32, L07807, doi:10.1029/2004GL022010, 2005. 
Wagner, T. and Platt, U.: Satellite mapping of enhanced BrO concentrations in the troposphere, Nature, 395, 486-490, 1998.

Warren, S. G. and Wiscombe, W. J.: A model for the spectral albedo of snow, II: snow containing atmospheric aerosols, J. Atmos. Sci., 37, 2734-2745, 1980.

Warren, S. G., Rigor, I. G., Untersteiner, N., Radionov, V. F., Bryazgin, N. N., Aleksandrov, Y. I., and Colony, R.: Snow depth on Arctic sea ice, J. Climate, 12, 1814-1829, 1999.

Weeks, W. F. and Hibler III, W. D.: On Sea Ice, Univ. Alaska Press, Fairbanks, Alaska, 2010.

Wennberg, P.: Bromine explosion, Nature, 397, 299-301, 1999.

Wesely, M. L.: Parameterization of surface resistances to gaseous dry deposition in regional-scale numerical models, Atmos. Environ., 23, 1293-1304, 1989.

Wessel, S., Aoki, S., Winkler, P., Weller, R., Herber, A., Gernandt, H., and Schrems, O.: Tropospheric ozone depletion in polar regions, a comparison of observations in the Arctic and Antarctic, Tellus B, 50, 34-50, 1998.

Wettlaufer, J. S.: Impurity effects in the premelting of ice, Phys. Rev. Lett., 82, 2516-2519, doi:10.1103/PhysRevLett.82.2516, 1999.

Wolff, E. W. and Paren, J. G.: A two-phase model of electrical conduction in polar ice sheets, J. Geophys. Res., 89, 9433-9438, 1984.
Wren, S. N., Donaldson, D. J., and Abbatt, J. P. D.: Photochemical chlorine and bromine activation from artificial saline snow, Atmos. Chem. Phys., 13, 9789-9800, doi:10.5194/acp-13-97892013, 2013.

Yang, X., Pyle, J. A., and Cox, R. A.: Sea salt aerosol production and bromine release: role of snow on sea ice, Geophys. Res. Lett., 35, L16815, doi:10.1029/2008GL034536, 2008.

Yokouchi, Y., Akimoto, H., Barrie, L. A., Bottenheim, J. W., Anlauf, K., and Jobson, B. T.: Serial gas chromatographic/mass spectrometric measurements of some volatile organic compounds in the Arctic atmosphere during the 1992 Polar Sunrise Experiment, J. Geophys. Res., 99, 25379-25389, doi:10.1029/94JD00227, 1994.

Zdanovskii, A. B.: New methods for calculating solubilities of electrolytes in multicomponent systems, Zhur. Fiz. Khim., 22, 14751485, 1948.

Zilitinkevich, S. S. and Esau, I. N.: The effect of baroclinicity on the equilibrium depth of neutral and stable planetary boundary layers, Q. J. Roy. Meteor. Soc., 129, 3339-3356, doi:10.1256/qj.02.94, 2003. 


\section{Appendix A}

\section{Analytical solution for wind-pumping ventilation in snowpack}

With a number of assumptions to simplify mathematical treatment, Cunningham and Waddington (1993) (hereafter CW93) derived an analytical solution from governing equations for 3-D Darcy's flow within porous snowpack. Primarily, (1) the shape of the snow surface (bumps) was assumed to follow a bi-directionally sinusoidal pattern, and (2) microphysical properties were assumed to be uniform in the snowpack. Upper and lower boundary conditions were given by pressure perturbations associated with a form drag against surface winds over sinusoidal micro-topography at the top of the snowpack (Eq. 18 in CW93) and the absence of air ventilation across the impermeable bottom of the snowpack (Eq. 14 in CW93), respectively. However, their analytical solution did not properly account for the lower boundary condition as dictated above, but corresponded to a snowpack (or a firn) permeable to infinite depth. After reworking the analytical solution for the vertical volume flux $\left(V_{z}\right)$ of ventilated air (Eq. (26) in CW93) and averaging it spatially over the horizontal domain of downward flow (which is balanced by upward flow in the remaining domain), we have obtained a corrected formula as follows:

$\bar{V}_{z}=\frac{6 k \rho_{\mathrm{air}}}{\pi \mu \lambda} \frac{h}{\lambda} \frac{\sqrt{\alpha_{\mathrm{AR}}^{2}+1}}{\alpha_{\mathrm{AR}}} U_{10}^{2} \times\left[C_{1} \exp \left(-\frac{z}{\delta}\right)-C_{2} \exp \left(\frac{z}{\delta}\right)\right]$,

where

$$
\begin{gathered}
\delta=\frac{\alpha_{\mathrm{AR}}}{\sqrt{\alpha_{\mathrm{AR}}^{2}+1}} \frac{\lambda}{2 \pi} \\
C_{1}=\frac{\exp \left(\frac{H_{\mathrm{SD}}}{\delta}\right)}{\exp \left(\frac{H_{\mathrm{SD}}}{\delta}\right)+\exp \left(-\frac{H_{\mathrm{SD}}}{\delta}\right)} \\
C_{2}=\frac{\exp \left(-\frac{H_{\mathrm{SD}}}{\delta}\right)}{\exp \left(\frac{H_{\mathrm{SD}}}{\delta}\right)+\exp \left(-\frac{H_{\mathrm{SD}}}{\delta}\right)}
\end{gathered}
$$

and $z$ is the distance from the top of the snowpack, $H_{\mathrm{SD}}$ is the mean snow depth $(=35 \mathrm{~cm}$, Warren et al., 1999; Sturm et al., 2002), $k$ is permeability $\left(=4 \times 10^{-9} \mathrm{~m}^{2}\right.$, Albert et al., 2002), $\mu$ is the dynamic viscosity of air, $U_{10}$ is the wind speed at $10 \mathrm{~m}$ height (estimated from $U_{2}$ ), $h$ is the vertical amplitude of bumps, $\lambda$ is the horizontal wavelength of bumps in the direction of wind, and $\alpha_{\mathrm{AR}}$ is the horizontal aspect ratio of bumps so that $\alpha_{\mathrm{AR}} \lambda$ gives the wavelength of bumps perpendicular to the direction of the wind.

The form drag on sea ice, as dictated by the three parameters, $h, \lambda$ and $\alpha_{\mathrm{AR}}$, in the equations above, results most likely from a combination of primary roughness elements such as ridging and self-organized snowdrifts created by the action of strong winds (Andreas, 1995). The morphology of sea ice is very complex and thus remains to be characterized adequately for modeling purposes such as ours, but previous field observations of sea ice micro-topography provide a clue (e.g., Sturm et al., 2002). Here we use $h=0.15 \mathrm{~m}, \lambda=10 \mathrm{~m}$ and $\alpha_{\mathrm{AR}}=0.2$, which we consider to be realistic to represent micro-topography on the first-year sea ice under windy conditions. 